\title{
Nurses in the lead
}

Citation for published version (APA):

Vogel, R. G. M. (2022). Nurses in the lead: empowering community nurse leaders to implement evidence into practice. [Doctoral Thesis, Maastricht University]. Gildeprint Drukkerijen.

https://doi.org/10.26481/dis.20220204rv

Document status and date:

Published: 01/01/2022

DOI:

10.26481/dis.20220204rv

Document Version:

Publisher's PDF, also known as Version of record

\section{Please check the document version of this publication:}

- A submitted manuscript is the version of the article upon submission and before peer-review. There can be important differences between the submitted version and the official published version of record.

People interested in the research are advised to contact the author for the final version of the publication, or visit the DOI to the publisher's website.

- The final author version and the galley proof are versions of the publication after peer review.

- The final published version features the final layout of the paper including the volume, issue and page numbers.

Link to publication

\footnotetext{
General rights rights.

- You may freely distribute the URL identifying the publication in the public portal. please follow below link for the End User Agreement:

www.umlib.nl/taverne-license

Take down policy

If you believe that this document breaches copyright please contact us at:

repository@maastrichtuniversity.nl

providing details and we will investigate your claim.
}

Copyright and moral rights for the publications made accessible in the public portal are retained by the authors and/or other copyright owners and it is a condition of accessing publications that users recognise and abide by the legal requirements associated with these

- Users may download and print one copy of any publication from the public portal for the purpose of private study or research.

- You may not further distribute the material or use it for any profit-making activity or commercial gain

If the publication is distributed under the terms of Article $25 \mathrm{fa}$ of the Dutch Copyright Act, indicated by the "Taverne" license above, 


\section{NURSES IN THE LEAD}

Empowering community nurse leaders to implement evidence into practice

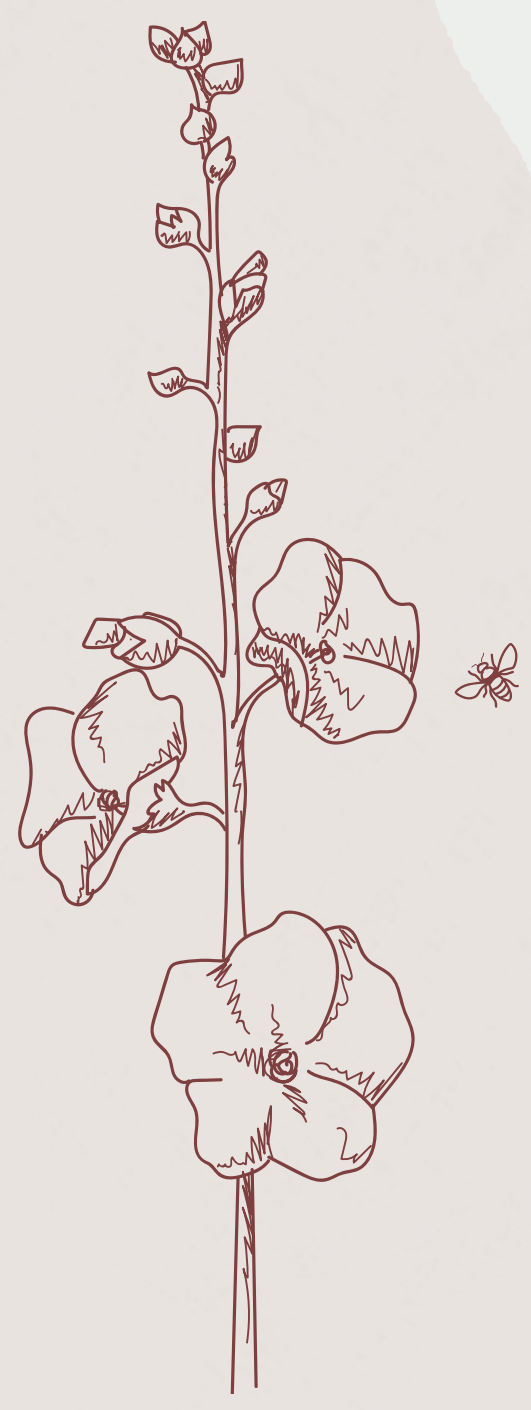

Ruth G. M. Vogel 



\section{NURSES IN THE LEAD}

Empowering community nurse leaders to implement evidence into practice 
The research presented in this dissertation was conducted at the Research Centre for Community Care, Academy of Nursing, Zuyd University of Applied Sciences, Heerlen, and at CAPHRI Care and Public Health Research Institute, Department of Health Services Research, of Maastricht University. CAPHRI participates in the Netherlands School of Public Health and Care Research CaRe. This research was conducted within the Living Lab in Ageing and Long-Term Care and funded by the Netherlands Organization for Health Research and Development, as part of the research line: 'Nurses in the Lead: towards High Quality Community Care' (grant 520003001) and by Maastricht University.

C Copyright Ruth Vogel, Maastricht 2021

All rights are reserved. No part of this book may be reproduced or transmitted in any form or by any means, without the written permission from the author or, where appropriate, the publisher of the article.

Cover design: Paula Conraads

Lay-out: Tiny Wouters

Printing: GildePrint 


\section{NURSES IN THE LEAD}

\section{Empowering community nurse leaders to implement evidence into practice}

\section{PROEFSCHRIFT}

Ter verkrijging van de graad van doctor aan de Universiteit Maastricht, op gezag van de Rector Magnificus, Prof. dr. Pamela Habibovic volgens het besluit van het College van Decanen,

in het openbaar te verdedigen op

vrijdag 4 februari 2022 om 14.00 uur

door

\section{Ruth Gonny Marcel Vogel}

geboren op 17 maart 1993

te Sittard 


\section{Promotores}

Prof. dr. S.M.G. Zwakhalen

Dr. H.J.L. van Rossum

\section{Co-promotor}

Dr. G.J.J.W. Bours

\section{Beoordelingscommissie}

Prof. dr. D.H.J.M. Dolmans (voorzitter)

Dr. R. Backhaus

Prof. dr. E.J. Finnema (Universitair Medisch Centrum Groningen)

Prof. dr. J.W.M. Muris

Dr. M.S. Nieuwboer (Hogeschool van Arnhem en Nijmegen) 


\section{Contents}

$\begin{array}{lll}\text { Chapter } 1 & \text { General introduction } & 7\end{array}$

Chapter 2 Nurse leadership in long-term care: a systematic review on leadership programs

Submitted for publication

Chapter 3 The content of the Nurses in the Lead programme for empowering community nurse leadership in implementing evidence Published in: Leadership in Health Services, 2021

Chapter 4 The perceived behavior and barriers of community care professionals in encouraging functional activities of older adults: the development and validation of the MAINtAIN-C questionnaire Published in: BMC Health Services Research, 2020

Chapter 5 Process evaluation of a programme to empower community nurse leadership

Published in: BMC Nursing, 2021

Chapter 6 Outcomes of the 'Nurses in the Lead' programme to empower community nurse leadership: a pre-post-test study Submitted for publication

Chapter 7 General discussion

Summary

Samenvatting

Impact

Dankwoord

About the author

List of publications 



\section{Background}

Community care is challenging due to the staff shortages, the rising number of older persons and the increased complexity of care ${ }^{1,2}$. Dutch community nurses fulfil a unique leadership role in offering community care; they lead care teams, determine the care needs of clients, collaborate with other disciplines and deliver care while improving clients' independence and quality of life. According to Rosendal ${ }^{3}$, nurses have a central position in dealing with the complexity of community care and should translate evidence into practice to improve the quality of care they deliver.

The studies included in this dissertation focused on how community nurses can be empowered in their leadership. Specifically, we focused on empowering community nurse leadership for the implementation of evidence. This chapter introduces the Dutch community care setting, nurse leadership and leadership for the implementation of evidence. The final paragraph presents the aims and the outline of this dissertation.

\section{The Dutch community care setting}

Globally, 9\% of the population was aged 65 years and over in 2019, and this rate is expected to increase to $16 \%$ by $2050^{1}$. In the Netherlands, $3.5 \%$ of all citizens received community care in 2018 , of which $75 \%$ were aged 67 years or older ${ }^{4}$. The Dutch government focuses on encouraging ageing in place and civic participation for as long as possible. Community care is increasingly being promoted instead of the more expensive institutionalised care ${ }^{5}$. Community care is comprised of personal care (e.g. washing), nursing care (e.g. wound treatment) and domestic services (e.g. house cleaning). Community care teams, comprised of bachelor-educated community nurses and 10-15 team members, are responsible for providing personal and nursing care ${ }^{2}$. The community nurse coordinates and organises the care provided by the team members $^{6}$, who can be bachelor- or vocational-trained registered nurses or secondarytrained certified nurse assistants or helping aids. The community nurse is also responsible for conducting care needs assessments to determine the best care for clients. As Henderson ${ }^{7}$ stated:

"The unique function of the nurse is to assist the individual, sick or well, in performance of those activities contributing to health or its recovery (or to peaceful death) that he would perform unaided if he had the necessary strength, will or knowledge and to do this in such a way as to help him gain independence as rapidly as possible".

The essence of this definition reflects the function of community nurses, as they determine care in consultation with clients while considering self-reliance and prevention $^{8}$. Community nurses tailor health, independence and quality of life to the 
needs of clients and the community ${ }^{9}$. Their unique and complex role requires leadership ${ }^{3}$.

\section{Nurse leadership}

The World Health Organization ${ }^{10}$ has called for nurses to take leadership, to respond to future challenges and establish a foundation for future nursing. The Institute of Medicine ${ }^{11}$ stated that leadership must become part of the profession of every nurse throughout every setting to ensure nurses can contribute to delivering high-quality care. In general, a strong consensus confirms leadership is a complex and multifaceted process used to influence, motivate and support others in achieving a common goal ${ }^{12,13}$. Within this dissertation, we adopted the definition of leadership by Heinen et al. ${ }^{14}$ as 'a process where nurses can develop observable leadership competencies and attributes needed to improve patient outcomes, personnel outcomes and organisational outcomes'.

Several leadership theories have been developed in nursing leadership research and have been used to guide leadership interventions over the past years, including clinical leadership, which strongly focuses on improving patient care ${ }^{15}$, and transformational leadership, which focuses on building relationships and guiding change through influence and inspiration ${ }^{16,17}$. Compelling evidence has supported the impact of nurse leadership as being vital to improving nursing outcomes ${ }^{18,19}$. Especially, leadership styles focused on relations with others were more commonly associated with improved nursing workforce outcomes, such as higher job satisfaction ${ }^{19,20}$, and patient outcomes, such as reduced medication errors ${ }^{21}$. Accordingly, an important goal of nurse leadership is the implementation of research evidence into daily practice to improve care outcomes $^{22}$. Facilitating the uptake of evidence is essential to providing high-quality care, and nurse leaders are designated to translate this evidence into practice. As such, an important aspect of community nurse leadership is to gain and share evidence to provide the best care for their clients.

\section{Leadership for the implementation of evidence}

To improve patient outcomes, community care practice must be underpinned by highquality research evidence. The relationship between leadership and the implementation of evidence has been well investigated ${ }^{19}$. Several factors related to the nature of the evidence, its context and the facilitation needed for successful change influence the implementation process ${ }^{23}$. Nurse leaders can influence these factors by creating a context conducive to implementation and facilitating the change process ${ }^{24-27}$. Important relations-oriented behaviours in this context acknowledge individual 
contributions, engage team members towards changes in practice, stimulate critical thinking and help nurses identify barriers ${ }^{16,28,29}$. Further, to bring about successful change in practice, a systematic implementation process is warranted ${ }^{30}$. This requires the ability to develop a structured implementation plan and both knowledge of research evidence and barriers and strategies for bringing evidence into practice ${ }^{31}$. Nurses also require the necessary skills to prioritise change and set outcomes and goals for the specific change in practice ${ }^{30,31}$. To enhance implementation success, the implementation strategies should target specific evidence ${ }^{30}$. Considering that encouraging older adults to be self-reliant is important in daily community care, implementing the most current evidence into practice to support this goal is essential. Accordingly, we developed a nurse leadership programme, called Nurses in the Lead (NitL), to empower community nurse leadership in implementing evidence. Specifically, we focused on evidence related to encouraging functional activities of older adults, including activities of daily living (e.g. washing, dressing) and instrumental ADL (e.g. preparing meals).

\section{Objectives and outline}

\section{Objectives}

The main objective of this dissertation is to study the empowerment of community nurses in their leadership for implementing evidence. Specifically, this dissertation aims to meet the following goals:

1) Provide insight into programmes to enhance the leadership of nursing staff in longterm care;

2) Develop a nurse leadership programme named Nurses in the Lead, for empowering community nurse leadership in implementing evidence targeted on encouraging functional activities;

3) Evaluate the leadership programme regarding leadership competencies of community nurses and the implementation processes of the programme in daily practice.

\section{Outline}

In Chapter 2, we report on a systematic review on existing leadership programmes to improve nurse leadership of nursing staff in long-term care. In Chapter 3, we present the NitL programme, consisting of two components: a systematic approach to empower community nurses in implementing evidence and training to empower community nurses in enabling team members to change their practice. In Chapter 4, we provide insight into a questionnaire that community nurses can use to measure the behaviour and barriers of the nurses in their teams in encouraging functional activities. In Chapter 5, we address the process evaluation of the NitL programme according to 
community nurses and their team members. In Chapter 6, we report on the evaluation of the NitL programme in terms of changes in community nurses' leadership behaviour and behaviour in encouraging functional activities by their team members. In Chapter 7 , we summarise the main findings of this dissertation and discuss the methodological and theoretical aspects. Finally, we provide the implications for research, practice and education. 


\section{References}

1. United Nations. World Population Ageing. Department of Economic and Social Affairs Population Division; 2019.

2. Panteia. De situatie op de arbeidsmarkt in de wijkverpleging. Ministerie van Volksgezondheid, Welzijn en Sport; 2020.

3. Rosendal H. Expertisegebied Wijkverpleegkundige [Community Nurses' Area of Expertise]: V\&VN; 2019.

4. Vektis. Factsheet Wijkverpleging. 2020.

5. van Hees S, Horstman K, Jansen M, Ruwaard D. How does an ageing policy translate into professional practices? An analysis of kitchen table conversations in the Netherlands: Hoe wordt een verouderingsbeleid vertaalt in de praktijk van professionals? Een analyse van keukentafelgesprekken in Nederland. European Journal of Social Work. 2020;23(2):215-26.

6. Postma J, Oldenhof L, Putters K. Organized professionalism in healthcare: articulation work by neighbourhood nurses. Journal of Professions and Organization. 2015;2(1):61-77.

7. Henderson V. The nature of nursing. The American journal of nursing. 1964:62-8.

8. den Boer J, Nieboer AP, Cramm JM. A cross-sectional study investigating patient-centred care, co-creation of care, well-being and job satisfaction among nurses. Journal of nursing management. 2017;25(7):577-84.

9. Steering Committee National Quality Framework for Community Care (Stuurgroep Kwaliteitskader Wijkverpleging). National Quality Framework for Community Care (Kwaliteitskader Wijkverpleging). 2018.

10. World Health Organization. Global strategic directions for strengthening nursing and midwifery 20162020. 2016.

11. Institute of Medicine. The Future of Nursing: Leading Change, Advancing Health. : National Academies Press Washington, DC; 2011.

12. Northouse PG. Introduction to leadership: Concepts and practice: Sage Publications; 2014.

13. Davidson PM, Elliott D, Daly J. Clinical leadership in contemporary clinical practice: implications for nursing in Australia. Journal of nursing management. 2006;14(3):180-7.

14. Heinen $M$, van Oostveen $C$, Peters J, Vermeulen $H$, Huis A. An integrative review of leadership competencies and attributes in advanced nursing practice. Journal of advanced nursing. 2019;75(11):2378-92.

15. Daly J, Jackson D, Mannix J, Davidson PM, Hutchinson M. The importance of clinical leadership in the hospital setting. Journal of Healthcare Leadership. 2014;6:75-83.

16. Giddens J. Transformational leadership: What every nursing dean should know. Journal of Professional Nursing. 2018;34(2):117-21.

17. Bass BM, Riggio RE. Transformational leadership: Psychology Press; 2006.

18. Hutchinson M, Jackson D. Transformational leadership in nursing: towards a more critical interpretation. Nursing inquiry. 2013;20(1):11-22.

19. Cummings GG, Tate K, Lee S, Wong CA, Paananen T, Micaroni SPM, et al. Leadership styles and outcome patterns for the nursing workforce and work environment: A systematic review. International journal of nursing studies. 2018;85:19-60.

20. Weberg D. Transformational leadership and staff retention: an evidence review with implications for healthcare systems. Nursing administration quarterly. 2010;34(3):246-58.

21. Wong CA, Cummings GG, Ducharme L. The relationship between nursing leadership and patient outcomes: a systematic review update. Journal of nursing management. 2013;21(5):709-24.

22. Harvey G, Gifford W, Cummings G, Kelly J, Kislov R, Kitson A, et al. Mobilising evidence to improve nursing practice: A qualitative study of leadership roles and processes in four countries. International journal of nursing studies. 2019;90:21-30.

23. Rycroft-Malone J, Kitson A, Harvey G, McCormack B, Seers K, Titchen A, et al. Ingredients for change: revisiting a conceptual framework. BMJ Quality \& Safety. 2002;11(2):174-80.

24. Aarons GA, Ehrhart MG, Farahnak LR. The Implementation Leadership Scale (ILS): development of a brief measure of unit level implementation leadership. Implementation science : IS. 2014;9.

25. Greenhalgh T, Robert G, Macfarlane F, Bate P, Kyriakidou O. Diffusion of innovations in service organizations: systematic review and recommendations. The Milbank Quarterly. 2004;82(4):581-629. 
26. Ovretveit J. Improvement leaders: what do they and should they do? A summary of a review of research. BMJ Quality \& Safety. 2010;19(6):490-2.

27. Li S-A, Jeffs L, Barwick M, Stevens B. Organizational contextual features that influence the implementation of evidence-based practices across healthcare settings: a systematic integrative review. Systematic reviews. 2018;7(1):72.

28. Farahnak LR, Ehrhart MG, Torres EM, Aarons GA. The influence of transformational leadership and leader attitudes on subordinate attitudes and implementation success. Journal of Leadership and Organizational Studies. 2020;27(1):98-111.

29. Aarons GA, Ehrhart MG, Farahnak LR, Hurlburt MS. Leadership and organizational change for implementation (LOCI): a randomized mixed method pilot study of a leadership and organization development intervention for evidence-based practice implementation. Implementation Science. 2015;10(1):11.

30. Grol R, Wensing M, Eccles M, Davis D. Improving patient care: The Implementation of Change in Health Care. Hoboken, New Jersey: John Wiley \& Sons; 2013.

31. Gifford WA, Graham ID, Ehrhart MD, Davies BL, Aarons GA. Ottawa model of implementation leadership and implementation leadership scale: mapping concepts for developing and evaluating theory-based leadership interventions. Journal of Healthcare Leadership. 2017;9:15. 



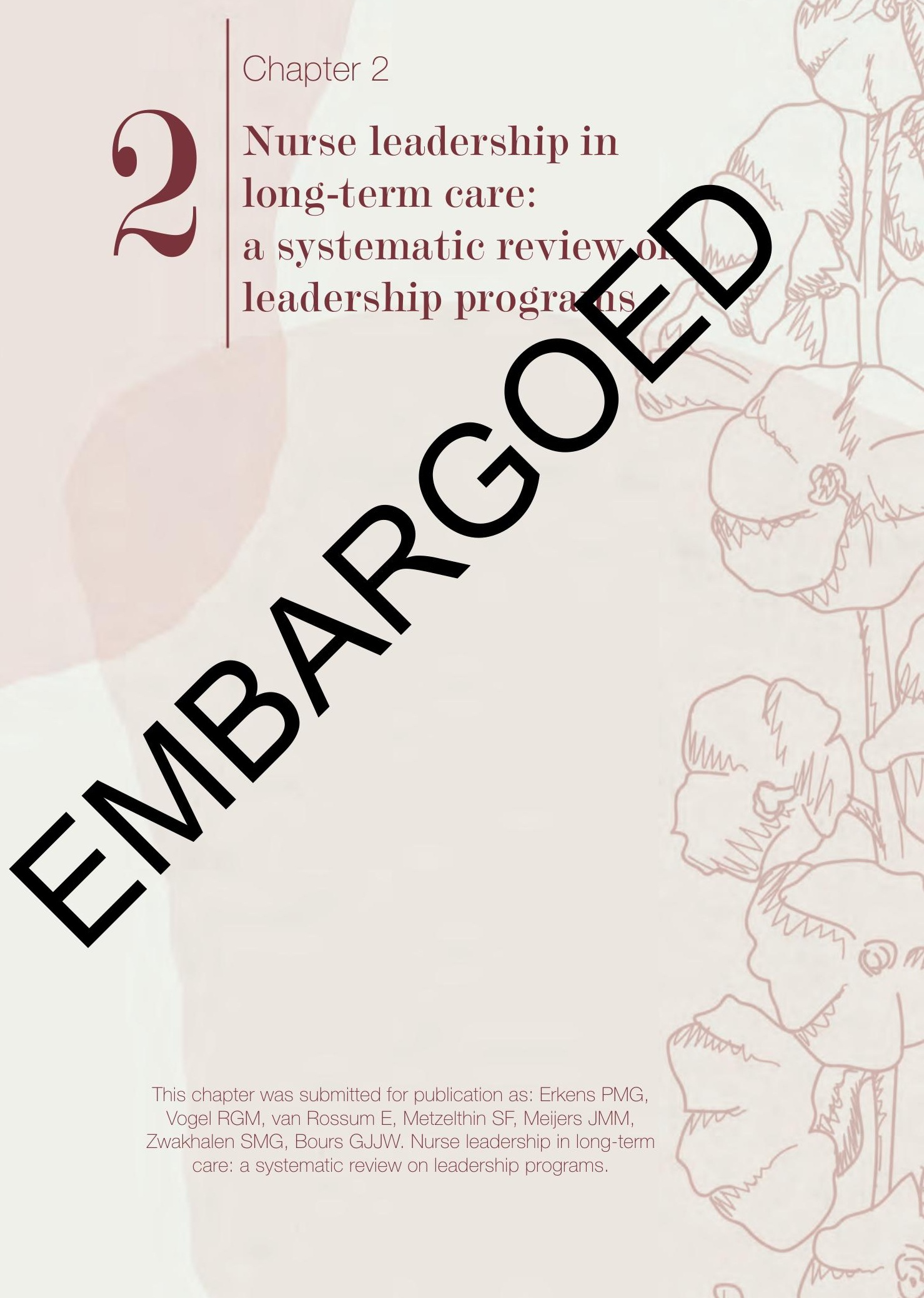




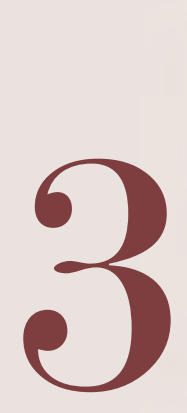

Chapter 3

The content of the Nurses in the Lead programme for empowering community nurse leadership in implementing evidence

This chapter was published as: Vogel, RGM, Bours GJJW, Erkens PMG, Metzelthin SF, Zwakhalen SMG, van Rossum E. The content of the Nurses in the Lead programme for empowering community nurse leadership. Leadership in Health Services (2021). https://doi.org/10.1108/LHS-08-2020-0063 


\section{Abstract}

\section{Purpose}

This study aims to provide a detailed description of the nurses in the lead (NitL) programme for empowering community nurse leadership in implementing evidence.

\section{Design/methodology/approach}

The NitL programme is described using the template for intervention description and replication-checklist.

\section{Findings}

The NitL programme consists of two components. The first component is a systematic approach with implementation steps and tools to empower community nurses in implementing evidence targeted at encouraging functional activities of older adults offered via a Web-based eLearning programme. The second component is training to empower community nurses in enabling team members to change their practice, which focussed on motivational interviewing, influencing behaviour, dealing with resistance to change and coaching delivered as a combination of group training in practice and background theory via a web-based eLearning programme.

\section{Research limitations/implications}

Further research is needed to evaluate the feasibility and effects of the NitL programme.

\section{Practical implications}

The NitL programme has been developed in cooperation with community nurses to meet their needs in practice and has the potential to develop leadership for the core tasks of community nurses.

\section{Originality/value}

The NitL programme has been developed to empower the leadership of community nurses in implementing evidence targeted at encouraging functional activities of older adults. The leadership role of community nurses is key for delivering high-quality care and implementing evidence within the community care setting for encouraging functional activities of older adults to preserve their independence. 


\section{Introduction}

Developments such as the aging European population, the increasing number of people with long-term conditions and the need for community-based care instead of institutionalised care require nurses with a high level of competency in the community ${ }^{1,2}$. In The Netherlands, community nurses have a unique leadership position, as they are in charge of community care teams that usually consist of 10-15 nurses working in community care (in this study, the term nurses refers to registered nurses, certified nurse assistants and helping aids). Furthermore, they determine, which and how much care is needed, provide care while enhancing selfreliance and quality of life of older adults and connect various professionals in the field $^{3}$. Community nurses are also expected to implement research evidence into practice to contribute to improving the delivery of high-quality community care. Given the importance of these community nurses within the community care setting, empowering their leadership competencies is an essential prerequisite.

It is widely agreed that leadership, in general, is a complex and multifaceted process, to influence others in achieving a common goal ${ }^{4,5}$. Specifically for nurses, leadership is regarded as essential to achieving optimal patient outcomes and workplace enhancement ${ }^{6}$. In this study, we followed the definition of nurse leadership as "a process where nurses can develop observable leadership competencies and attributes needed to improve patient outcomes, personnel outcomes and organisational outcomes", put forth by Heinen et al. ${ }^{7}$. Especially community nurse leaders, because of their role in community care, can have a significant impact on improving patient outcomes by implementing evidence into practice ${ }^{3}$. Implementation science aims to take research evidence into practice, to maximise the provision of high-quality care ${ }^{8,9}$. When looking at factors associated with successful implementation, it has been stated that a systematic uptake of evidence is required, and that the implementation approach should match the problems in practice, to achieve change ${ }^{9-11}$. Community nurses should develop an implementation plan to conduct the implementation step-bystep; therefore, they need knowledge on evidence-based best practices, barriers to change and implementation strategies ${ }^{12}$. Furthermore, skills for prioritising change, targeting specific outcomes and goal setting are important ${ }^{10,12}$. Another important factor for successful implementation is using leader behaviours to enable others to affect the desired changes in practice ${ }^{12,13}$. Changing behaviour is a major challenge, and is most effective if the leaders know what it is exactly that should be changed ${ }^{14}$. Nurses can lead the process of changing patterns in practice and develop implementation plans that include strategies to facilitate change ${ }^{15}$. Important behaviours in this process are engaging others towards the change in practice, appreciating individual contributions of team members, using influence to create a purpose for the change, stimulating critical thinking of team members and helping to look at concerns in a different light ${ }^{16-18}$. These behaviours are characterised by stimulating, inspiring and 
motivating others to encourage the acceptance of change in practice ${ }^{16,17}$ and can result in making team members more receptive to bringing about change ${ }^{19}$.

Previously, other programmes have been developed to empower nurse leadership. Most of these programmes have not focussed on leadership for the implementation of evidence but on professional development, for example, through mentoring and coaching or enhancing leaders' use of empowering behaviours ${ }^{20-24}$. Some programmes have focussed on enhancing managerial leadership 25,26 or leadership for the implementation of specific guidelines ${ }^{27,28}$. To enhance leadership for the implementation of evidence, the actions of leaders should be tailored specifically to the evidence that is implemented ${ }^{10}$. For the community care setting, it is important to implement evidence focussed on encouraging functional activities of older adults to maintain their functional independence. Older adults can be encouraged to perform activities of daily living (ADL; e.g. washing) and instrumental ADL (e.g. preparing meals) independently ${ }^{29,30}$. However, nurses are traditionally used to take over these activities and perform them on behalf of older adults ${ }^{31-33}$.

To our best knowledge, none of the earlier developed leadership programmes has focussed on empowering community nurse leadership for implementing evidence targeted at encouraging functional activities. Thus, the nurses in the lead (NitL) programme was developed to empower community nurse leadership in implementing evidence targeted at encouraging functional activities of older adults. This article aims to provide a detailed description of the content of the NitL programme using the template for intervention description and replication (TIDieR) checklist. Describing the content of the programme is important to provide insights for its implementation in practice and the dissemination of the programme in community care.

\section{Methods}

\section{Development process}

The NitL programme was developed between February 2017 and July 2017. An existing toolbox $^{34}$ to guide nurses in implementing evidence for encouraging functional activities served as the basis to develop the programme. This translating innovations into practice (TIP) toolbox was developed based on the Implementation of Change mode ${ }^{10}$ and had been used in an earlier study to guide nurses in nursing homes during the implementation process ${ }^{34}$. In Appendix Table S3.1, the TIP toolbox is presented. The toolbox comprises six practical steps to develop an implementation plan and several implementation tools, such as a questionnaire to measure behaviours and barriers of nurses in encouraging functional activities. For developing the NitL programme, the TIP toolbox was assessed on appropriateness and feasibility for the community care setting by community nurses, after which its content was adapted. Furthermore, these community nurses were asked, which competencies (related to stimulating, inspiring and motivating) they needed to enable their team members to change practice and 
which training they might need to strengthen these competencies. This was processed, and the NitL programme was developed, consisting of two components. The first component is a systematic approach with six implementation steps and five practical implementation tools to empower community nurses in the systematic implementation of evidence targeted at encouraging functional activities of older adults, which is offered via a web-based eLearning programme. The second component is training to empower community nurses in enabling team members to change their practice delivered via group training and a web-based eLearning programme. The training focuses on how motivational interviewing can be applied, how to influence behaviour and deal with resistance to change and how to coach care teams in practice, for example, during a peer supervision meeting. Researchers and nurses working in community care assessed the content validity of the NitL programme, which was shown to be adequate. In Appendix 3.2, the development process and assessment of the content validity are described in detail.

To ensure transparency, we used the TIDieR checklist ${ }^{35}$ to report the content of the programme. While the checklist emphasises intervention trials, it is increasingly used for descriptions to enhance reflection, clarification and reporting of interventions ${ }^{36}$. The TIDieR checklist is an extension of the Consolidated Standards of Reporting Trials 2010 statement and the Standard Protocol Items 2013 statement, which was developed based on a combination of literature, experts and a Delphi survey ${ }^{35}$. It consists of 12 items, including the name and the fidelity of the programme. As items 10 to 12 of the checklist (modifications, adherence and fidelity) can only be completed after the implementation of the programme, items 1-9 are presented in this article.

\section{Results}

Items 1 and 2: Brief name, theory and aim of the elements essential to the intervention

\section{Brief name}

The NitL programme.

\section{Theory}

The first component of the programme, the systematic approach, is based on the implementation of the change model ${ }^{10}$. The model uses a stepwise approach for implementing change in a specific healthcare setting. The model comprises seven practical steps, namely, developing a proposal for change; analysing the actual performance and targets for change; analysing the target group and setting; and developing and selecting strategies and measures to change practice. Further, it includes developing, testing and execution of the implementation plan, integrating 
changes in routines and evaluating and adapting the plan ${ }^{10}$. These seven steps were merged into six practical steps within the TIP toolbox and used in this form within the NitL programme. Furthermore, the systematic approach includes practical implementation tools, and one tool is an example of an evidence-based innovation that can be implemented into community care. This innovation is based on the concept of reablement, which focuses on helping people to learn how to perform functional activities themselves, instead of taking over activities. It strives to preserve independence in older adults and prevent functional decline $\mathrm{e}^{37,38}$.

The second component of the NitL programme is training to empower community nurses in enabling team members to change their practice. To develop the training, we were inspired by the high impact learning that lasts model of Dochy et al. ${ }^{39}$. The model states that community nurses should feel a sense of urgency (i.e. a drive to learn) to facilitate learning and be aware and in control of their responsibilities in the learning process. Therefore, the training within the NitL programme is mainly based on community nurses' individual needs in practice to strengthen their drive to learn. As the nurses were able to provide input for the content of the training, they might perceive the training as relevant, which can increase their responsibility for learning. The model also states that it is important to promote collaborative learning and peer interaction in small groups of community nurses, which is why group training is included for community nurses to share their experiences. The content of the training is based on the most common needs of these community nurses in combination with the established theory. We incorporated the theory on behaviour and interaction by Leary ${ }^{40}$, the theory on motivational interviewing by Miller et al. ${ }^{41}$ and the theory of Goossens ${ }^{42}$ on how to coach care teams in practice, such as during a peer supervision meeting.

\section{Aim}

The NitL programme aims to empower community nurses' leadership in implementing evidence, targeted at encouraging functional activities.

\section{Items 3 and 4 . What: materials and procedures}

\section{Component 1}

A systematic approach to empower community nurses in implementing evidence targeted at encouraging functional activities. The first component of the programme is a systematic approach with six implementation steps and five practical implementation tools based on the Implementation of Change model ${ }^{10}$.

The approach is offered via a web-based eLearning programme (Table 3.1 for a detailed overview of the systematic approach.). The six implementation steps can guide the community nurses in systematically developing an implementation plan. In the first implementation step, community nurses can formulate a proposal for change and 
specific, measurable, attainable, realistic and time-bound (SMART) goals. The second step includes the assessment of the current performance of team members and the barriers and facilitators. The third step is selecting and tailoring implementation strategies. In the fourth step, the community nurses plan the implementation process and execute it in practice. The fifth step is making sure that the improvements are integrated within practice routines. The sixth step is evaluating and revising the implementation plan.

To complete the steps, several practical implementation tools are included. The first is a template for developing an implementation plan that guides community nurses in completing the abovementioned implementation steps. The second tool is an example of a completed implementation plan. See Implementation tool two (continuation of Table 3.1), with the description of the first step.

Table 3.1 Detailed overview of Component 1 - the systematic approach of the nurses in the lead programme.

\begin{tabular}{|c|c|c|c|c|c|}
\hline \multicolumn{6}{|c|}{ Component 1 - A systematic approach } \\
\hline \multicolumn{3}{|l|}{ Implementation steps } & \multicolumn{3}{|l|}{ Actions } \\
\hline \multicolumn{3}{|c|}{$\begin{array}{l}\text { Step } 1 \text { Formulating a proposal for change and SMART } \\
\text { (specific, measurable, attainable, realistic and time } \\
\text { bound) goals }\end{array}$} & \multicolumn{3}{|c|}{ Formulate a proposal for change } \\
\hline \multirow{2}{*}{\multicolumn{3}{|c|}{$\begin{array}{l}\text { Step } 2 \text { Assessing the performance of professionals in } \\
\text { encouraging functional activities and related barriers. } \\
\text { Formulating SMART targets for change }\end{array}$}} & \multicolumn{3}{|c|}{$\begin{array}{l}\text { Administer the MAINtAIN questionnaire and } \\
\text { analyse the data with the Excel tool }\end{array}$} \\
\hline & & & \multicolumn{3}{|c|}{$\begin{array}{l}\text { Create an overview of the least and most } \\
\text { mentioned barriers }\end{array}$} \\
\hline \multicolumn{3}{|c|}{ Step 3 Selecting and tailoring strategies } & \multicolumn{3}{|c|}{$\begin{array}{l}\text { Formulate SMART targets for change } \\
\text { Select strategies related to the professionals, } \\
\text { the team and the organisation }\end{array}$} \\
\hline \multicolumn{3}{|c|}{ Step 4 Planning the implementation process } & \multirow{2}{*}{\multicolumn{3}{|c|}{$\begin{array}{l}\text { Tailor these strategies to the barriers } \\
\text { Develop a realistic planning and programme } \\
\text { stakeholders to perform the strategies in practice } \\
\text { Decide, which actions are necessary to make the } \\
\text { innovation last in practice }\end{array}$}} \\
\hline \multicolumn{3}{|c|}{$\begin{array}{l}\text { Step } 5 \text { Integrating improvement within the normal } \\
\text { practice routines }\end{array}$} & & & \\
\hline Step 6 Evaluating (anc & d revising) the plan & & \multicolumn{3}{|c|}{$\begin{array}{l}\text { Decide on how the implementation process is } \\
\text { going to be evaluated }\end{array}$} \\
\hline \multicolumn{6}{|l|}{ Implementation tools } \\
\hline \multicolumn{2}{|c|}{$\begin{array}{ll}\text { Tool } 1 \text { Template for } & \text { Tool } 2 \text { Example of } \\
\text { developing an } & \text { a completed } \\
\text { implementation plan } & \text { implementation } \\
& \text { plan }\end{array}$} & \multicolumn{2}{|c|}{$\begin{array}{l}\text { Tool } 3 \text { Example of an } \\
\text { evidence-based innovation } \\
\text { that can be implemented }\end{array}$} & $\begin{array}{l}\text { Tool } 4 \\
\text { MAINtAIN-C } \\
\text { questionnaire }\end{array}$ & $\begin{array}{l}\text { Tool } 5 \text { Overview } \\
\text { of implementation } \\
\text { barriers and } \\
\text { strategies }\end{array}$ \\
\hline
\end{tabular}


Continuation of Table 3.1 Implementation tool 2

Example of a completed implementation plan

(1) Step 1: Develop a proposal for change.

Specify what needs to change, how much this needs to change, who has to effect the change and for when this should happen. Based on this, a specific, measurable, attainable, realistic and time-bound (SMART) goal for the entire implementation process can be formulated.

A. What do we want to change?

We want to set goals for performing functional activities within the care plan of the clients and encourage these clients to achieve these goals.

B. How much should change (for example, how many clients)?

Goals have to be set for $80 \%$ of the clients.

C. Who should do this?

All nurses within the team.

D. For when?

Within 10 weeks.

Purpose (Based on A-D):

Goal: We want all nurses within the team [C] to set goals for performing functional activities within the care plans for $80 \%$ of the clients $[A / B]$ within 10 weeks $[D]$ and to encourage these clients to achieve these goals $[\mathrm{A}]$.

Based on the concept of reablement, the third tool is an evidence-based innovation that can be implemented, focussing on helping people to learn how to perform functional activities themselves ${ }^{37,38}$. The fourth tool is the MAastrlcht Nurses Activities INventory for Community Care (MAINtAIN-C) questionnaire to establish the current behaviours and barriers of team members in encouraging functional activities in practice. It consists of the Behaviours scale (20 items) to measure the perceived behaviours in encouraging functional activities (Cronbach's alpha: 0.92) and Barriers scales, to measure the perceived barriers in encouraging functional activities related to the clients' context (seven items) (Cronbach's alpha: 0.78 ) and to professional, social and organisational contexts (21 items) (Cronbach's alpha: 0.83$)^{43}$. A complementary Excel-based analysis tool is provided to the community nurses to analyse the answers given on the MAINtAIN-C questionnaire. The fifth tool is an overview of barriers that the nurses might perceive and strategies that can be selected to address these. The strategies and barriers address four different domains, namely, the client, professional, social and organisational contexts.

\section{Component 2}

Training to empower community nurses in enabling team members to change practice. The second component is training to empower community nurses in enabling team members to change their practice. The training is a combination of group training in practice and background theory via a web-based eLearning programme. It focuses on how motivational interviewing can be applied ${ }^{41}$, how to influence behaviour and deal with resistance to change and how to coach care teams in practice ${ }^{40,42}$, such as during a peer supervision meeting based on the Balint ${ }^{44}$ method. The experiences of the 
community nurses in practice are addressed during the group training, and they are supported to give each other feedback on their experiences.

\section{Item 5: Who: expertise and background of interventionist}

For the first component, an interventionist with experience in implementation processes, preferably with a nursing background, should be involved to support the nurses during the development of the implementation plan. For the second component, an interventionist preferably with experience in training nurses in group dynamics and communication should be involved.

\section{Items 6-8: How, when, how much and the location where the intervention will occur}

The NitL programme is targeted at community nurses and runs for eight months (Figure 3.1 for an overview of the programme). During the first two months, the nurses develop an implementation plan by using the systematic approach incorporated in the web-based elearning programme. The nurses work together on their implementation plan in groups of two or three and have weekly meetings to discuss the progress of their implementation plan. Bimonthly, they meet with an interventionist and receive support in developing the plan. During the next six months, the nurses implement their plan in practice and receive the training. They meet monthly with an interventionist to evaluate the implementation process. Each community nurse receives 4 hours of group training. The background theory is presented via the web-based elearning programme and constantly available to use and re-use when needed.

Figure 3.1 Overview of the nurses in the lead programme.
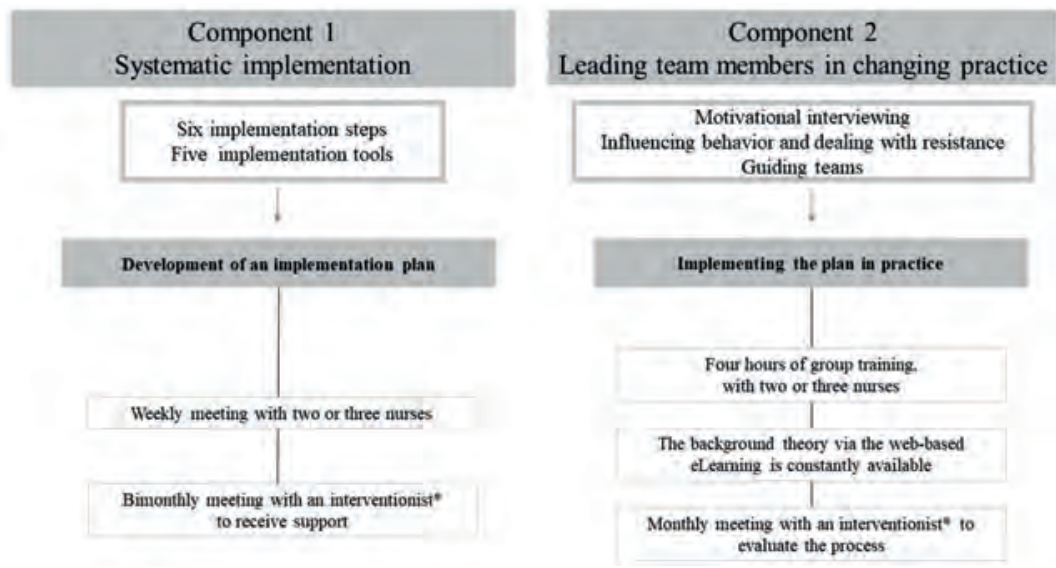

Notes: *For the first component, an interventionist with experience in implementation processes, preferably with a nursing background should be involved. For the second component, an interventionist preferably with experience in training nurses in group dynamics and communication should be involved. 


\section{Item 9: Tailoring}

The content of the training as described serves as the basis for the group training. However, the sessions are tailored for each group. The community nurses' needs, based on their experiences in practice, are addressed during the group training, where they are supported to give each other feedback on their experiences. For example, if nurses indicate that they find it difficult to deal with resistance to change from certain nurses in their teams, this issue is then addressed during the training.

\section{Discussion}

This article described the content of the NitL programme for empowering community nurse leadership in implementing evidence targeted at encouraging functional activities of older adults. The programme consists of two components. The first component is a systematic approach to empower community nurses in the implementation of evidence targeted at encouraging functional activities of older adults. The second component is training to empower community nurses in enabling team members to change their practice, which is delivered via group training and a web-based eLearning programme. The competencies focussed upon in the NitL programme are important for community nurses to fulfil their leadership role in contributing to improving care outcomes. The content of the training was developed based on the most common needs of community nurses in combination with established theory, but not necessarily restricted to one single leadership theory or domain. The training focuses on behaviours related to stimulating, inspiring and motivating others, which can be regarded as transformational leadership behaviours ${ }^{16}$. Leadership for systematic implementation and enabling others to change practice could yet also be viewed in the perspective of clinical leadership, which is regarded as essential for the provision of effective patient care ${ }^{45}$ through, for example, collaborating with professionals and implementing innovations ${ }^{7}$. Clinical leadership has a strong focus on patients through collective behaviours, whereas transformational leadership highlights the charisma of leaders ${ }^{46}$. Clinical leadership can, however, be defined and conceptualised in various ways ${ }^{46}$ and comprises more leader characteristics and attributes than currently focussed upon in the NitL programme.

Previous leadership programmes have not focussed on community nurse leadership for the implementation of evidence to encourage functional activities. Various frameworks and theories of leadership are used within previously developed programmes, such as the theory of organisational leadership ${ }^{47}$ by Gifford et al. ${ }^{48}$ and the full range leadership mode ${ }^{49}$ by Richter et al. ${ }^{25}$. Similar to Holleman et al. ${ }^{27}$ the implementation of the change mode ${ }^{10}$ is used in the NitL programme as the theory of implementation. Similar to our study, other programmes have also focussed on leadership for implementing specific practices, such as the implementation of guidelines to prevent diabetic foot ulcers $^{10}$ or guidelines for the management of intertrigo ${ }^{27}$. 
This study has some limitations. The content of the NitL programme was developed based on the needs of individual community nurses. It could be the case that primarily motivated community nurses were included, who had an interest in leadership and an already strong level of developed leadership competencies. Whether the programme content is feasible for community nurses on a larger scale remains to be demonstrated. However, the involvement of the community nurses provided deeper insight into their needs, which can have a positive impact on the adoption of the programme in practice and the development of community nurse leadership programmes in general $\mathrm{I}^{50}$. Furthermore, to disseminate the programme in the wider community care context, related to the implementation of other evidence-based practices, the systematic approach should be tailored to the specific evidence to be implemented ${ }^{10}$.

This study has several strengths as well. It provides a detailed description of the content of the NitL programme. Descriptions of programmes are often lacking in evaluation studies, which makes them more difficult to implement, evaluate and disseminate ${ }^{51}$. An effective description is even more important for multicomponent programmes tailored to the target group and setting, such as the NitL programme. The complexity of multicomponent interventions and of the context into which these are implemented requires detailed descriptions to allow replication, interpret findings and distinguish and compare interventions ${ }^{36,52}$. The TIDieR checklist was useful to accommodate the detailed reporting of the NitL programme. Further, NitL comprises a combination of group training in practice and background theory via a web-based eLearning programme. Previous studies have shown that this kind of blended learning can increase the effectiveness of interventions in practice ${ }^{26,53,54}$. Finally, the content of the training is based on the learning needs of community nurses, which might increase their drive and responsibility to learn ${ }^{39}$. This might also diminish the risk of a toogeneric programme, which might not suit the needs of individual leaders ${ }^{55}$.

\section{Conclusion}

The NitL programme aims to empower community nurse leadership in implementing evidence targeted at encouraging functional activities of older adults. The programme has been developed in cooperation with community nurses to meet their needs in practice and has the potential to develop leadership for the core tasks of community nurses in practice. It should be considered that the feasibility of the NitL programme has not yet been tested in terms of duration and intensity in practice, which is recommended before moving onto a larger-scale effect study. Therefore, the programme next needs to be implemented in community care nursing practice and evaluated for its feasibility and effects. 


\section{References}

1. Spasova S, Baeten R, Vanhercke B. Challenges in long-term care in Europe. Eurohealth 2018;24(4):7-12.

2. Genet N, Boerma W, Kroneman M, Hutchinson A, Saltman R. Home Care across Europe: Case Studies, WHO. 2013.

3. Rosendal H. Expertisegebied Wijkverpleegkundige [Community Nurses' Area of Expertise]. V\&VN. 2019.

4. de Lange W, Kars MC, Poslawsky IE, Schuurmans MJ, Hafsteinsdóttir TB. Postdoctoral nurses' experiences with leadership and career development: a qualitative study. Journal of Nursing Scholarship 2019;51(6):689-698.

5. Northouse PG. Introduction to Leadership: Concepts and Practice, Sage Publications. 2014.

6. Hutchinson M, Jackson D. Transformational leadership in nursing: towards a more critical interpretation. Nursing Inquiry 2013;20():11-22.

7. Heinen M, van Oostveen C, Peters J, Vermeulen H, Huis A. An integrative review of leadership competencies and attributes in advanced nursing practice. Journal of Advanced Nursing 2019;75(11): 2378-2392.

8. Eccles MP, Mittman BS. Welcome to implementation science. Implementation Science 2006;1(1):1.

9. Westerlund A, Nilsen P, Sundberg L. Implementation of implementation science knowledge: the research-practice gap paradox. Worldviews on Evidence-Based Nursing 2019;16(5):332.

10. Grol R, Wensing M, Eccles M, Davis D. Improving Patient Care: The Implementation of Change in Health Care, John Wiley and Sons, Hoboken, NJ. 2013.

11. Wensing M, Grol R. Knowledge translation in health: how implementation science could contribute more. BMC Medicine 2019;17(1):88.

12. Gifford WA, Graham ID, Ehrhart MD, Davies BL, Aarons GA. Ottawa model of implementation leadership and implementation leadership scale: mapping concepts for developing and evaluating theory-based leadership interventions. Journal ofHealthcare Leadership 2017;9:15.

13. Aarons GA, Ehrhart MG, Farahnak LR, Sklar M. Aligning leadership across systems and organizations to develop a strategic climate for evidence-based practice implementation. Annual Review of Public Health, Vol. 2014;35(1):255-274.

14. Curtis K, Fry M, Shaban RZ, Considine J. Translating research findings to clinical nursing practice. Journal of Clinical Nursing 2017;26:862-872.

15. Boehm LM, Stolldorf DP, Jeffery AD. Implementation science training and resources for nurses and nurse scientists. Journal of Nursing Scholarship 2020;52(1):47-54.

16. Farahnak LR, Ehrhart MG, Torres EM, Aarons GA. The influence of transformational leadership and leader attitudes on subordinate attitudes and implementation success. Journal of Leadership and Organizational Studies. 2010;27(1):98-111.

17. Giddens J. Transformational leadership: what every nursing dean should know. Journal of Professional Nursing 2018;34(2):117-121.

18. Aarons GA, Ehrhart MG, Farahnak LR, Hurlburt MS. Leadership and organizational change for implementation (LOCI): a randomized mixed method pilot study of a leadership and organization development intervention for evidence-based practice implementation. Implementation Science 2015;10(1):11.

19. Bommer WH, Rich GA, Rubin RS. Changing attitudes about change: longitudinal effects of transformational leader behavior on employee cynicism about organizational change. Journal of Organizational Behavior 2005;26(7):733-753.

20. Fielden SL, Davidson MJ, Sutherland VJ. Innovations in coaching and mentoring: implications for nurse leadership development. Health Services Management Research 2009;22(2):92-99.

21. Roberson C. Development and delivery of a clinical leadership programme for integrated community teams. British Journal of Community Nursing 2019;24(11)518-522.

22. Leigh JA, Wild J, Hynes C, Wells S, Kurien A, Rutherford J, Rosen L, Ashcroft T, Hartley V. Transforming community services through the use of a multidimensional model of clinical leadership. Journal ofClinical Nursing 2015;24:749-760.

23. Lankshear S, Huckstep S, Lefebre N, Leiterman J, Simon D. The ALIVE program: developing a web-based professional development program for nursing leaders in the home healthcare sector. Nursing Leadership 2010;23:61-74. 
24. MacPhee M, Dahinten V, Hejazi S, Laschinger H, Kazanjian A, McCutcheon A, Skelton-Green J,O'BrienPallas L. Testing the effects of an empowerment-based leadership development programme: part 1leader outcomes. Journal of Nursing Management 2014;22(1):4-15.

25. Richter A, Lornudd C, von Thiele Schwarz U, Lundmark R, Mosson R, Skoger UE, Hirvikoski T, Hasson H. (2020), Evaluation of iLead, a generic implementation leadership intervention: mixed-method preintervention-postintervention design. BMJ Open 2020;10(1): e033227..

26. Johannessen T, Ree E, Strømme T, Aase I, Bal R, Wiig S. Designing and pilot testing of a leadership intervention to improve quality and safety in nursing homes and home care (the SAFE-LEAD intervention). BMJ Open 2019;9(6):e027790.

27. Holleman G, van Tol M, Schoonhoven L, Mintjes-de Groot J, van Achterberg T. Empowering nurses to handle the guideline implementation process: identification of implementation competencies. Journal of Nursing Care Quality 2014;29(3):E1-E6.

28. Gifford WA, Davies BL, Tourangeau A, Lefebre N. Developing team leadership to facilitate guideline utilization: planning and evaluating a 3-month intervention strategy", Journal of Nursing Management 2011;19(1):121-132.

29. Winkel A, Langberg $\mathrm{H}$, Wæhrens EE. Reablement in a community setting. Disability and Rehabilitation 2015;37(15):1347-1352.

30. Kempen GIJM, Doeglas DM, Suurmeijer TPMB. Groningen Activity Restriction Scale (GARS): Een Handleiding, UMCG/Rijksuniversiteit Groningen, Research Institute SHARE. 2012.

31. Oliver D, Foot C, Humphries R. Making Our Health and Care Systems Fit for an Ageing Population, King's Fund London. 2014.

32. Beresford B, Mann R, Parker G, Kanaan M, Faria R, Rabiee P, Weatherly H, Clarke S, Mayhew E, Duarte A. Work package $2 \mathrm{~b}$ : delivering reablement-practitioner views. Health Services and Delivery Research 2019;7(16):.

33. Whitehead PJ, Worthington EJ, Parry RH, Walker MF, Drummond AE. Interventions to reduce dependency in personal activities of daily living in community dwelling adults who use homecare services: a systematic review. Clinical Rehabilitation 2015;29(11):1064-1076.

34. Kuk NO, Bours GJJW, Hamers JPH, Kempen GIJM, Zijlstra GAR. Feasibility of the translating innovations into practice-toolbox (TIP-toolbox): a mixed-methods study for implementing activity innovations in nursing homes. Geriatric Nursing 2017;38(6):498-504.

35. Hoffmann TC, Glasziou PP, Boutron I, Milne R, Perera R, Moher D, Altman DG, Barbour V, Macdonald H, Johnston $M$. Better reporting of interventions: template for intervention description and replication (TIDieR) checklist and guide. BritishMedical Journal 2014;348:1687.

36. Cotterill S, Knowles S, Martindale AM, Elvey R, Howard S, Coupe N, Wilson P, Spence M. Getting messier with TIDieR: embracing context and complexity in intervention reporting. BMC Medical Research Methodology 2018;18(1):12.

37. Aspinal F, Glasby J, Rostgaard T, Tuntland H, Westendorp RGJ. New horizons: reablement - supporting older people towards independence. Age and Ageing 2016;45(5):574-578.

38. Tessier A, Beaulieu MD, McGinn CA, Latulippe R. Effectiveness of reablement: a systematic review. Healthc Policy 2016;11(4):49-59.

39. Dochy F, Berghmans I, Koenen A. High Impact Learning, Lemma/Boom, Utrecht. 2015.

40. Leary T. Interpersonal Diagnosis of Personality: A Functional Theory and Methodology for Personality Evaluation,Wipf and Stock Publishers. 2004.

41. Miller WR, Rollnick S. Motivational Interviewing: Helping People Change, Guilford Press. 2012.

42. Goossens W. Integrale procesbegeleiding van groepen, in Remmerswaalea, J. (Ed.), Handboek Werken, Leren en Leven Met Groepen C, Vol. 2600, Learning And LivingWith Groups. 2004.

43. Vogel RGM, Bours GJJW, Metzelthin SF, Erkens PMG, van Breukelen GJP, Zwakhalen SMG, et al. The perceived behavior and barriers of community care professionals in encouraging functional activities of older adults: the development and validation of the MAINtAIN-C questionnaire. BMC Health Services Research. 2020;20(1):907.

44. Balint M. The doctor, his patient, and the illness. The Lancet 1955;265(6866):683-688.

45. Brown A, Dewing J. The next generation of clinical leaders; future proofing preparation. Journal of Nursing Management 2016;24(5):569-570.

46. Daly J, Jackson D, Mannix J, Davidson PM, Hutchinson M. The importance of clinical leadership in the hospital setting. Journal of Healthcare Leadership 2014;6:75-83. 
47. Yukl G. Leadership in Organizations, Pearson, Upper River Saddle, NJ. 2006.

48. Gifford WA, Davies BL, Graham ID, Tourangeau A, Woodend AK, Lefebre N. Developing leadership capacity for guideline use: a pilot cluster randomized control trial. Worldviews on Evidence-Based Nursing, Vol. 2013;10(1):51-65.

49. Avolio BJ. Full Range Leadership Development, Sage Publications. 2010.

50. Rogers EM. Diffusion of Innovations, Simon and Schuster, New York, NY City. 2010.

51. Hoffmann TC, Erueti C, Glasziou PP. Poor description of non-pharmacological interventions: a remediable barrier to evidence use in practice. BMJ 2013;347(10):1076.

52. Wells M, Williams B, Treweek S, Coyle J, Taylor J. Intervention description is not enough: Evidence from an in-depth multiple case study on the untold role and impact of context in randomised controlled trials of seven complex interventions. Trials 2012;13(1):95.

53. Pereira JA, Pleguezuelos E, Merí A, Molina-Ros A, Molina-Tomas MC, Masdeu C. Effectiveness of using blended learning strategies for teaching and learning human anatomy. Medical Education 2007;41(2):189-195.

54. Liu Q, Peng W, Zhang F, Hu R, Li Y, Yan W. The effectiveness of blended learning in health professions: systematic review and meta-analysis. Journal of Medical Internet Research 2016;18(1):e2.

55. Darragh M, Traynor V, Joyce-McCoach J. Effectiveness of interventions for the development of leadership skills among nurses: a systematic review protocol. JBI Database of Systematic Reviews and Implementation Reports, Vol. 2016;14(6):3-13.

56. Proctor E, Silmere H, Raghavan R, Hovmand P, Aarons G, Bunger A, Griffey R, Hensley M. Outcomes for implementation research: conceptual distinctions, measurement challenges, and research agenda", Administration and Policy in Mental Health and Mental Health Services Research, Vol. 2011;38(2):6576.

57. Flick U. An Introduction to Qualitative Research, Sage Publications, Thousand Oaks, CA. 2009.

58. Mokkink LB, Terwee CB, Patrick DL, Alonso J, Stratford PW, Knol DL, Bouter LM, de Vet HCW. The COSMIN checklist for assessing the methodological quality of studies on measurement properties of health status measurement instruments: an international Delphi study. Quality of Life Research 2010;19(4):539-549. 


\section{Appendix 3.1}

\section{Overview of the translating innovations into practice-toolbox ${ }^{34}$}

Table S3.1 Brief description of the TIP-Toolbox.

\begin{tabular}{|c|c|c|c|c|c|c|}
\hline \multicolumn{7}{|c|}{ Six implementation steps } \\
\hline 1) & 2) & 3) & 4) & \multicolumn{2}{|l|}{ 5) } & 6) \\
\hline $\begin{array}{l}\text { Formulating a } \\
\text { proposal for change } \\
\text { in practice with } \\
\text { clear targets }\end{array}$ & $\begin{array}{l}\text { Assessing the } \\
\text { performance of } \\
\text { nursing staff and } \\
\text { existing barriers } \\
\text { and formulating } \\
\text { specific targets for } \\
\text { change }\end{array}$ & $\begin{array}{l}\text { Selecting and } \\
\text { tailoring a set } \\
\text { of strategies }\end{array}$ & $\begin{array}{l}\text { Planning the } \\
\text { implementation } \\
\text { process }\end{array}$ & \multicolumn{2}{|c|}{$\begin{array}{l}\text { Integrating } \\
\text { improvement } \\
\text { within routines } \\
\text { in practice }\end{array}$} & $\begin{array}{l}\text { Evaluating } \\
\text { (and } \\
\text { revising) the } \\
\text { plan }\end{array}$ \\
\hline \multicolumn{7}{|c|}{ Five implementation tools } \\
\hline 1 & 2. & 3. & 4. & & \multicolumn{2}{|l|}{5.} \\
\hline $\begin{array}{l}\text { A template for } \\
\text { establishing the } \\
\text { implementation } \\
\text { plan }\end{array}$ & $\begin{array}{l}\text { An example of a } \\
\text { completed } \\
\text { implementation } \\
\text { plan }\end{array}$ & $\begin{array}{l}\text { An example of } \\
\text { an innovation } \\
\text { for } \\
\text { encouraging } \\
\text { functional } \\
\text { activities }\end{array}$ & $\begin{array}{l}\text { The MAastrlcht } \\
\text { Activities INvent } \\
\text { (MAINtAIN)- } \\
\text { questionnaire, w } \\
\text { MAINtAIN-beha } \\
\text { and barriers scal } \\
\text { measuring perce } \\
\text { behaviours, barr } \\
\text { and facilitators i } \\
\text { encouraging acti } \\
\text { residents }\end{array}$ & $\begin{array}{l}\text { urses } \\
\text { ry } \\
\text { ours the } \\
\text { ged } \\
\text { rs, } \\
\text { ities of }\end{array}$ & \multicolumn{2}{|c|}{$\begin{array}{l}\text { An overview of } \\
\text { implementation barriers } \\
\text { and related strategies to } \\
\text { overcome these barriers }\end{array}$} \\
\hline
\end{tabular}

Notes: The TIP-toolbox guides nurses in nursing homes to sustainably implement evidence-based innovations. The toolbox was developed together with nursing home professionals and seemed feasible to guide nurses in implementing innovations ${ }^{34}$. The TIP-toolbox is based on the implementation of change model ${ }^{10}$ and comprises six implementation steps to develop a structured and tailored implementation plan and five implementation tools. The toolbox takes the form of a paper booklet and can also be viewed digitally (PDF). 


\section{Appendix 3.2}

\section{Development process of the nurses in the lead programme}

\section{Development of component 1 - adapting the translating innovations into practice- toolbox}

To adapt the TIP-toolbox, convenience sampling was used to recruit seven bacheloreducated community nurses if they were employed as a bachelor-educated nurse and not involved in the data collection of another study. The nurses were selected by the managers of two long-term care organisations in The Netherlands. The seven invited nurses all participated. Six nurses were female, two nurses had also a master's degree and they had a median age of 34 years old (Range 26-56), median work experience of 14 years (Range 7-38) and the median work hours per week were 32 (Range 24-36). The TIP-toolbox was assessed by the community nurses on its appropriateness (the perceived fit and relevance for the community care setting) and feasibility (whether it could be successfully implemented in the community care setting $)^{56}$. The nurses could propose adaptations, and they were invited to attend six meetings, in where they first individually assessed the toolbox by providing comments on the content, followed by a group discussion, guided by Flick ${ }^{57}$, on its appropriateness and feasibility. Two researchers (two authors) evaluated their comments and discussed the proposed adaptations, according to the comments of the community nurses, phrases and words within the TIP-toolbox were simplified to make it more understandable for use in practice. The practical tools were adapted in content and wording to fit the community care setting, namely, the example of a completed implementation plan and the overview of barriers and strategies. The MAINtAIN questionnaire (Appendix Table S3.1, the fourth tool) was adapted by modifying the wording and excluding and adding items, resulting in the MAINtAIN-C, see Vogel et al. $^{43}$. Furthermore, the content was incorporated in a web-based eLearning programme according to the preference of the community nurses. Eventually, this led to the first component of the NitL programme.

Development of component 2 - needs assessment of the community nurses in enabling team members to change practice

In the same six meetings, the community nurses were asked, which competencies related to stimulating, inspiring and motivating their team members to change practice and which training they might need to strengthen these competencies. Two researchers (two authors) analysed their needs. The nurses first suggested that it was indeed highly relevant to receive training on how to enable team members to change practice. Specifically, they wanted to learn how to motivate their team members during a change process, how to deal with different behaviours and resistance to change and learn more about the process of guiding teams effectively during their monthly meetings in practice. The training would ideally involve both group training and a web- 
based eLearning programme. Eventually, this training was developed based on the needs of the community nurses in collaboration with a research expert experienced in training nurses in group dynamics and communication, leading to the second component of the NitL programme.

\section{Assessment of the content validity}

Four research experts were consulted to assess the content validity of the entire NitL programme. Other research experts and community care professionals were consulted to assess the content validity of the adapted MAINtAIN-C questionnaire, for the details see Vogel et al. ${ }^{43}$. The four research experts reviewed the relevance of the content of the NitL programme (whether all the included content was relevant for community nurse leadership in implementing evidence to encourage functional activities), and the comprehensiveness of the NitL programme (whether the key content related to community nurse leadership was included). They also reviewed the comprehensibility (whether the content of the NitL programme was understood and appropriately worded $)^{58}$. The researchers considered the content validity to be adequate and found the included content relevant. They suggested making the programme more comprehensive by adapting the third tool (an example of an evidence-based innovation) to a more community-care-based, evidence-based innovation and suggested the concept of reablement ${ }^{29}$. Furthermore, two researchers commented on the comprehensibility, stating that the presentation of the content within the webbased eLearning programme should be more appealing; this suggestion resulted in the use of short movies. The researchers, however, found it useful to present the content of the NitL programme via the web-based eLearning programme. 



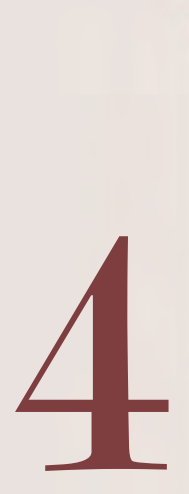

Chapter 4

The perceived behavior and barriers of community care professionals in encouraging functional activities of older adults:

the development and validation of the MAINtAIN-C questionnaire

This chapter was published as: Vogel RGM, Bours GJJW, Metzelthin SF, Erkens PMG, van Breukelen GJP,

Zwakhalen SMG, van Rossum E. The perceived behavior and barriers of community care professionals in encouraging functional activities of older adults: the development and validation of the MAINtAIN-C questionnaire. BMC Health Services Research 20, 907 (2020). https://doi.org/10.1186/s12913-020-05762-w 


\section{Abstract}

\section{Background}

Community care professionals need to encourage older adults in performing functional activities to maintain independence. However, professionals often perform functional activities on behalf of older adults. To change this, insights into the behavior and barriers of professionals in encouraging activities are required. In the current study, the MAINtAIN questionnaire, which was developed for nursing homes, was adopted. The objectivewas to create a modified version that is suitable for measuring behavior and barriers of community care professionals in encouraging functional activities of clients in the community care setting. The overall aims were to assess the content validity, construct validity, and internal consistency of the modified version.

\section{Methods}

Data was collected by qualitative and quantitative methods in two phases. During phase one, the MAINtAIN was assessed on appropriateness and feasibility by community nurses $(N=7)$, and the adapted questionnaire was assessed on content validity by research experts $(N=9)$ and community care professionals $(N=18)$. During phase two, the psychometric properties of the adapted MAINtAIN-C were assessed in community care professionals $(N=80)$. Construct validity was evaluated by an Exploratory Factor Analysis (EFA), and internal consistency was determined by calculating Cronbach's alpha coefficients.

\section{Results}

The formulation, verbs, and wording of the MAINtAIN were adapted; some items were excluded and relevant items were added, resulting in the MAINtAIN-C with two scales, showing good content validity. The Behaviors scale (20 items) measures perceived behavior in encouraging functional activities, expressing good internal consistency (Cronbach's alpha: .92). The Barriers scale measures barriers in encouraging functional activities related to two dimensions: 1 ) the clients' context ( 7 items), with good internal consistency (.78); and 2) the professional, social, and organizational contexts (21 items), showing good internal consistency (.83).

\section{Conclusions}

The MAINtAIN-C seems promising to assess the behavior and barriers of community care professionals in encouraging functional activities. It can be used to display a possible difference between perceived and actual behavior, to develop strategies for removing barriers in encouraging activities to foster behavioral change. The results also provide guidance for further research in a larger sample to obtain more insight into the psychometric properties. 


\section{Background}

The current ageing policy in the Netherlands is focused on enabling older adults to maintain independence in daily living and continue living in their homes as long as possible ${ }^{1}$. This implies that more older adults remain in the community to prevent or postpone institutional care ${ }^{2}$. To facilitate the current ageing policy, individuals need to have the ability to perform functional activities of daily living (ADL) (such as washing, dressing $^{3}$ ) and instrumental ADL (IADL) (such as preparing meals ${ }^{3}$ ) by their own $n^{4,5}$. In the Netherlands, however, older adults who need support in functional activities can receive community care, which comprises nursing care (e.g., personal care) and domestic services (e.g., cleaning). Nursing care is provided by teams with a mix of community care professionals (e.g., bachelor- and vocationally-educated nurses, certified nurse assistants, and helping aids), while domestic support workers are more involved in providing domestic services ${ }^{6}$. Bachelor-educated community nurses fulfil a lead role in the teams since they coordinate the care process and conduct needs assessments to determine which and how much care is necessary.

It is important that community care professionals encourage older adults to engage in functional activities ${ }^{7}$ and to be active during daily care activities. For example, by using verbal instructions or assistive devices during bathing, older adults can wash themselves, instead of professionals doing it for them ${ }^{8}$. However, community care professionals do not always have the competencies, that is, attitude, knowledge and skills to encourage older adults in functional activities ${ }^{9,10}$. They are often performing care activities on behalf of older adults instead of encouraging them to perform these activities as independently as possible $e^{10,11}$. Further insights are needed into the current behavior of professionals and into the factors, the professionals encounter as barriers.

Existing questionnaires generally focus only on measuring the role of nurses in, for example, encouraging physical activity ${ }^{11,12}$. However, for measuring the role of nurses in encouraging functional activities, the MAastrlcht Nurses Activities INventory (MAINtAIN) questionnaire was developed. This questionnaire measures the behavior and barriers of nurses in nursing homes in encouraging functional activities ${ }^{12}$. The questionnaire consists of two scales, namely the Behaviors scale for measuring the perceived behavior of professionals in encouraging functional activities, and the Barriers scale for measuring the related barriers to this behavior. The Behaviors scale comprises three subscales with 19 nine-point scaled items measuring the extent to which professionals stimulate residents in performing ADL (e.g., dressing), IADL (e.g., making the bed), and miscellaneous activities (e.g., encouraging physical activity as part of the care plan). The three subscales showed good internal consistency, Cronbach's alpha ranged from to $0.83^{13}$. The MAINtAIN-Barriers scale comprises 33 nine-point scaled items measuring barriers and facilitators related to the clients' context, as well as the professional, social (i.e., the team functioning), and organizational (i.e., how things work within the organization) contexts $^{14}$. The MAINtAIN was developed based on Restorative Care literature, an approach to improve functions of older adults ${ }^{15-19}$ and on 
literature about evidence-based nursing interventions and innovations ${ }^{20,21}$. The usability and content validity of the MAINtAIN were established involving experts, nursing staff, and residents ${ }^{12}$.

The MAINTAIN seemed promising for use in nursing home care. The usability study indicated that completing the questionnaire was not difficult and that it had clear items and response options. The number of missing values was low and a floor or ceiling effect was shown for a few items ${ }^{12}$. However, this setting is different from the community care setting. For example, while the nursing home professionals provide the care in teams at the nursing home wards, the community care professionals provide care at the clients' homes ${ }^{22}$. Therefore, adaptation of the MAINtAIN is necessary to make it applicable and valid for using it for community care professionals ${ }^{23}$. In the current study, the MAINtAIN questionnaire is adopted. The objective is to create a modified version that is suitable for measuring behavior and barriers of community care professionals in encouraging functional activities of clients in the community care setting. The overall aims are to assess the content validity, construct validity, and internal consistency of the modified version. The specific aims are to answer the research questions:

1. Which items of the MAINtAIN questionnaire should be adapted to make it appropriate and feasible for the community care setting, and what is the content validity of the adapted questionnaire?

2. What is the construct validity and internal consistency of the adapted questionnaire?

\section{Phase 1. Assessing the appropriateness and feasibility of the MAINtAIN and assessing the content validity of the adapted questionnaire}

\section{Methods}

A prospective study design using qualitative and quantitative methods to collect data was conducted. Data were collected in two phases. During phase one, the MAINtAIN was assessed on appropriateness and feasibility by community nurses, and the adapted questionnaire was assessed on content validity by research experts and community care professionals. Data were collected between February 2017 and July 2017. 


\section{Measures}

\section{MAINtAIN-questionnaire}

The questionnaire consists of two scales, namely the Behaviors scale for measuring the perceived behavior of professionals in encouraging functional activities, and the Barriers scale for measuring the related barriers to this behavior. The Behaviors scale comprises three subscales with 19 nine-point scaled items measuring the extent to which professionals stimulate residents in performing ADL (e.g., dressing), IADL (e.g., making the bed), and miscellaneous activities (e.g., encouraging physical activity as part of the care plan). The three subscales showed good internal consistency, Cronbach's alpha ranged from 0.77 to $0.83^{13}$. The MAINtAIN-Barriers scale comprises 33 nine-point scaled items measuring barriers and facilitators related to the clients' context, as well as the professional, social (i.e., the team functioning), and organizational (i.e., how things work within the organization) contexts $^{14}$.

\section{Groningen activity restriction scale (GARS)}

The GARS measures disability in ADL and IADL. The self-report questionnaire comprises two subscales, measuring ADL (11 items) and IADL (seven items), with four response options per item, ranging from one = able to perform the activity without any difficulty, to four = unable to perform the activity independently. The total score for disability ranges from 18 to 72 , with higher scores indicating more disability, and the Cronbach's alpha for the subscales has shown to be 0.82 and 0.80 , respectively ${ }^{24,25}$.

\section{Consensus-based standards for the selection of health measurement instruments (COSMIN)-checklist}

The checklist ${ }^{26}$ comprises 12 boxes to assess if studies on measurement properties meet the requirements and to assess the different measurement properties included, such as the internal consistency, reliability and construct validity. An additional box evaluates the quality of a study on interpretability. Several experts in the field of measurement with different backgrounds were involved in the development of the COSMIN checklist.

\section{Participants and procedure}

Seven bachelor-educated community nurses were invited to assess the appropriateness and feasibility of the MAINtAIN. It was expected that their lead role in the community care teams made them most suitable for this assessment. Convenience sampling was used to recruit the nurses, in collaboration with two managers of two long-term care organizations that provide community care in the South of the Netherlands. Inclusion criteria were: 1) employed as a bachelor-educated nurse and 2) not involved in the data collection of another study. The managers of the organizations selected the community nurses, who were each in charge of one community care team. All the invited nurses 
$(\mathrm{N}=7)$ participated in the study. Six nurses were female, five were bachelor-educated and two had obtained a master's degree. The median age was 34 years old (range 26-56), they had a median work experience of 14 years (range 7-38), and the median work hours per week were $32 \mathrm{~h}$ (range 24-36). Next, research experts and community care professionals were invited to assess the content validity of the adapted questionnaire. Nine research experts from Maastricht University and Zuyd University of Applied Sciences were invited to participate in this phase, including Authors SFM, EVR, PMGE and SMGZ, and all the nine research experts participated in the study. Three research experts were male and six were female, three research experts also had a background in nursing. Furthermore, convenience sampling was used to recruit community care professionals from another long-term care organization that provided community care in the Netherlands. Inclusion criteria were: 1) employed as a bacheloror vocationally-educated nurse, certified nurse assistant, helping aid or nursing student; and 2) not involved in the data collection of another study. Based on these criteria, the managers of the organizations selected 20 community care professionals. Eighteen of the 20 community care professionals participated in the study. The community care professionals were all female: five professionals worked as a bachelor-educated nurse, two professionals worked as a vocationally-educated nurse, and eleven professionals worked as a certified nurse assistant or helping aid. The median age was 46 years (range 25-60), the median work experience was 18 years (range 4-41), and the median work hours per week was 27 (range 20-36).

To assess the appropriateness (i.e., the perceived fit or relevance for a given setting) and feasibility (i.e., the extent to which it can be successfully used or carried out within a given setting $)^{27}$ of the MAINtAIN, the community nurses were invited to attend four meetings. Each meeting followed the same procedure, and different items were assessed. First, the nurses could individually assess each item on the appropriateness and feasibility for community care. They could propose adaptations for the formulation and wording, suggest which specific nursing home items were not relevant, and suggest additional relevant items to measure the behavior and barriers in the community care setting. Second, a group discussion ${ }^{28}$ took place during the meeting, regarding the appropriateness and feasibility of the items. One researcher (author RGMV) was the moderator and took additional field notes ${ }^{28}$. All the comments of the individual nurses were gathered after the meetings.

To assess the content validity of the adapted MAINtAIN, the nine research experts received the questionnaire via e-mail. To assess the content validity, they used the COSMIN checklist ${ }^{26}$. They assessed the content validity by reviewing the name, description, the instructions, the response options, and the relevance (i.e., whether all the included items were relevant), comprehensiveness (i.e., whether all key items were included), and comprehensibility (i.e., whether the items were understood and appropriately worded). The 20 community care professionals received a paper-based version of the adapted MAINtAIN. They were invited to assess the content validity by completing the questionnaire and reviewing the comprehensibility. Half of the 
professionals received items formulated based on the plural pronoun, "We" (as in the original MAINtAIN questionnaire; in other words, "In my team, we closely follow"), and half of them with items formulated based on the singular pronoun "I." This was done to assess if the adapted formulation would better fit the context, since community care professionals individually perform care activities at the clients' homes. Next to this, background characteristics of the nurses, the community care professionals, and the research experts (e.g., age and years of experience) were assessed.

\section{Data analysis}

The comments of the community nurses, the research experts, and the community care professionals, as well as the field notes from the group discussions with the nurses were gathered and summarized. Two researchers (Authors RGMV and GJJB) evaluated the comments and discussed the appropriateness and feasibility until consensus was reached and, if needed, adaptations were incorporated ${ }^{29}$. The additional items for the Behaviors scale (i.e., items that were not in the MAINtAIN but suggested by the nurses to be important for the adapted questionnaire for community care) were clustered according to the Groningen Activity Restriction Scale (GARS) ${ }^{3}$. The additional relevant items for the community care were clustered in either ADL or IADL, based on the clustering of the GARS. The additional items for the Barriers scale were clustered according to the original domains of the MAINtAIN questionnaire.

\section{Results}

\section{Adaptation of the MAINtAIN and content validity of the MAINtAIN-C}

The MAINtAIN was adapted in formulation (changed to the singular pronoun, "I," to better fit the context), in verbs and wording to make it suitable for community care. Furthermore, specific nursing home items were excluded (i.e., two items for the Behaviors scale and four items for the Barriers scale), and relevant items for community care were added (i.e., four items for the Behaviors scale and four items for the Barriers scale). Furthermore, the name changed to the MAastrlcht Nurses Activities INventory for Community Care (MAINtAIN-C). See Table 4.1 for an overview of all the adaptations. The original MAINtAIN included both facilitators and barriers but was used to measure barriers which is why we reversed the positively formulated items and interpreted all items as barriers.

\section{Final version of the MAINtAIN-C}

See Table 4.2 and Table 4.3 for an overview of the final items of the MAINtAIN-C. The MAINtAIN-C Behaviors scale contained 20, 9-point scaled items and assessed the 
degree to which community care professionals perceived to encourage functional activities related to ADL (11 items), IADL (5 items), and general activities (4 items). Answer options ranged from "one = never, to five = sometimes, to nine = always." The MAINtAIN-C Barriers scale assessed related barriers in encouraging functional activities of community-dwelling older adults, containing 33, 9-point scaled items, with factors relating to the clients' context (10 items), as well as the professionals (10 items), social (i.e., the team functioning) ( 6 items), and organizational ( 7 items) contexts. Answer options ranged from "one $=$ never, to five $=$ sometimes, to nine = always" and "one = completely disagree, five $=$ neither agree nor disagree, nine $=$ completely agree".

Table 4.1 Adaptations to the MAINtAIN questionnaire.

\begin{tabular}{|c|c|}
\hline Aspect & Adaptations \\
\hline Name & $\begin{array}{l}\text { The name of the questionnaire changed to the MAastrlcht Nurses Activities INventory } \\
\text { for Community Care (MAINtAIN-C). }\end{array}$ \\
\hline Formulation & $\begin{array}{l}\text { The formulation of all the items changed to the singular pronoun, "I," to better fit the } \\
\text { context, since community care professionals individually perform care activities. This } \\
\text { was further supported by comments of two community care professionals, stating } \\
\text { that they found it difficult to answer the questions on behalf of their team members. }\end{array}$ \\
\hline Verbs & $\begin{array}{l}\text { The IADL items changed to the verbs, "I discuss" (MAINtAIN-C, instead of "I } \\
\text { encourage" (original MAINtAIN)), since these activities are performed by domestic } \\
\text { support workers, who are not the end users of the MAINtAIN-C. }\end{array}$ \\
\hline Wording & $\begin{array}{l}\text { The wording of items was adapted to make them suitable for community care; for } \\
\text { example, from "We prepare sandwiches for residents, even if they can do this } \\
\text { themselves" (original MAINtAIN Behaviors, item 9), to "I discuss with clients if they } \\
\text { can prepare their meals independently" (adapted MAINtAIN Behaviors item 12). }\end{array}$ \\
\hline \multirow[t]{2}{*}{ Excluded items } & $\begin{array}{l}\text { For the Behaviors scale, two specific nursing home items were excluded; for example, } \\
\text { item 10: "We encourage residents to help set and clear the table." }\end{array}$ \\
\hline & $\begin{array}{l}\text { For the Barriers scale, four specific nursing home items were excluded from the } \\
\text { questionnaire since they were considered less relevant for community care; for } \\
\text { instance, item 8: "Residents on my ward consider it perfectly normal to have others } \\
\text { move them instead of moving about themselves." }\end{array}$ \\
\hline \multirow[t]{2}{*}{ Added Items } & $\begin{array}{l}\text { For the Behaviors scale, four specific community care items were added; for instance, } \\
\text { new item 14: "I advise clients about the added value of consulting other disciplines } \\
\text { (e.g., physical therapy) to encourage the independent performance of ADLs, since } \\
\text { they were considered relevant for measuring behavior in the community care } \\
\text { setting." }\end{array}$ \\
\hline & $\begin{array}{l}\text { For the Barriers scale, four specific community care items were added; for example, } \\
\text { new item 10: "An overburdened family or informal caregiver limits clients in } \\
\text { performing ADLs and IADLs independently." }\end{array}$ \\
\hline Order & $\begin{array}{l}\text { The order of the items was changed to cluster activities as much as possible, based on } \\
\text { the clustering of the GARS for the Behaviors scale, }{ }^{3} \text { as well as the original clustering of } \\
\text { the original MAINtAIN for the Barriers scale. }\end{array}$ \\
\hline Number of items & $\begin{array}{l}\text { For the Behaviors scale, the number of items changed from } 19 \text { to } 20 . \\
\text { For the Barriers scale, the number of items remained the same as the original } \\
\text { MAINtAIN ( } 33 \text { items). }\end{array}$ \\
\hline
\end{tabular}


Table 4.2 MAINtAIN-C Behaviors.

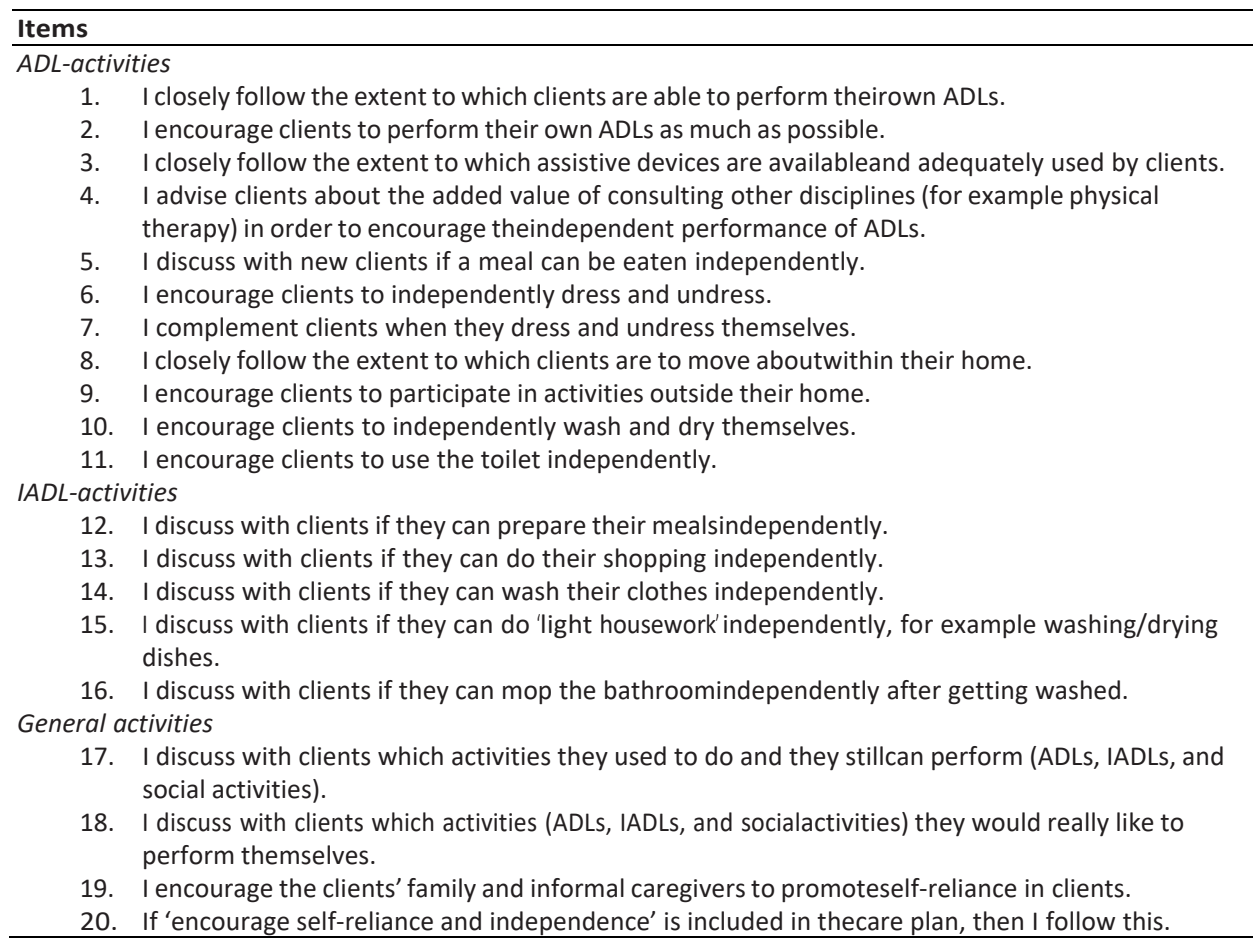

The MAINtAIN-C was translated from Dutch to English in two steps. First, one bilingual independent translator working as a researcher and professional translator, who also translated the original MAINTAIN questionnaire, and one author (RGMV), both translated the MAINTAIN-C into English. Second, the differences between these two versions and the original MAINtAIN were discussed by two researchers (RGMV, GJJB) until consensus was reached on a final version ${ }^{29}$. 
Table 4.3 MAINtAIN-C Barriers.

\section{Items}

\section{Context of the clients}

1. Clients are often able to control factors that influence their situation.

2. Clients are often able to perform ADLs more independently than they now do.

3. I see that encouraging physical activity has a positive effect on clients.

4. The capability of family or informal caregivers to encourage clients in the independent performance of ADLS and IADLs is sufficient.

5. Clients are afraid to walk on their own, without help from others.

6. Clients ask for help with ADLs so that they can get extra attention.

7. Family or informal caregivers expect the nurses and nurse assistants to take over the activities that clients themselves can still perform.

8. Clients do not want to perform activities themselves such as bathing or opening/closing curtains even if they still can.

9. Financial limitations restrict clients in performing ADLs and IADLs independently.

10. An overburdened family or informal caregiver limits clients in performing ADLs and IADLs independently.

Context of the professionals

11. I think that organizing my work so that clients are ready on time is more important than clients performing ADLs independently.

12. I am afraid that clients will hurt themselves if I encourage them to walk alone.

13. It is primarily the responsibility of the physical therapist or occupational therapist to encourage clients to perform activities.

14. Within my team, we think that it is important to encourage clients to perform ADLs as much as possible independently.

15. Within my team, we think that it is our task to inform the family or informal caregivers about the importance of clients performing activities independently.

16. I expect that encouraging ADLs and IADLs has no effect on how clients function.

17. Within my team, sufficient expertise is available to encourage clients to be as independent as possible in performing ADLs (such as bathing, moving about).

18. Encouraging independence as much as possible in clients' ADLs, IADLs and social activities gives me less time for other things.

19. I find it difficult to encourage clients to be self-reliant and independent.

20. If I want, I am able to allow clients to perform ADLs and IADLs more independently.

The social context (the team functioning)

21. Within my team, the collaboration with experts (for example occupational or physical therapists) is not good enough to encourage clients in performing ADLs as independently as possible.

22. I can count on enough support from my colleagues when I allow clients to perform ADLs and IADLs as independently as possible.

23. The manager of my team considers it important that clients perform ADLs and IADLs as independently as possible.

24. I speak to my colleagues when I hear that they perform activities that clients can still perform themselves.

25. The team discusses how we can encourage clients to perform ADLs and IADLs as independently as possible.

26. Within my team, it is our routine to take over the ADLs and IADLs (such as making sandwiches) for our clients.

The organizational context

27. My organization is not geared towards involving clients in the performance of ADLs and IADLs (such as independently bathing and dressing or preparing a meal).

28. In my organization, there are enough people available with knowledge about how to encourage self-reliance and independent performance of activities by clients.

29. My organization offers the possibility to follow internal or external courses that focus on encouraging clients' physical activity.

30. In my organization, we do not have agreements or guidelines concerning how we can encourage clients' physical activity.

31. I have inadequate time to activate clients to be self-reliant because of the needs assessment determined by the community nurse in my team.

32. Encouraging self-reliance and independence has a high priority in my organization.

33. There is a structural shortage of staff available to encourage clients to perform ADLs and IADLs (such as independently bathing and dressing or preparing a meal) as independently as possible. 


\section{Phase 2. Assessing the construct validity and internal consistency of the final adapted questionnaire}

\section{Methods}

During phase two, the psychometric properties of the final adapted questionnaire were assessed in a sample of community care professionals. Data were collected between September 2017 and March 2018.

\section{Participants}

The team members of the seven community care nurses that participated in phase one were recruited to assess the construct validity and internal consistency. There were no additional inclusion criteria for the team members. In total, 80 community care professionals were eligible for the study.

\section{Data collection}

Before completing the questionnaire, the community care professionals received a link with a personal account to log in via an online program in which they could complete the questionnaire and they were allowed to provide comments to the questions. Furthermore, background characteristics (e.g., age and years of experience) were assessed. Between two and 4 weeks after the initial invitation, reminder emails to complete the questionnaire were sent to the non-respondents.

\section{Data analysis}

Data were analyzed using IBM SPSS Statistics 25.0 for Windows ${ }^{30}$. For the Barriers scale, the scores of the positively formulated items were reversed so that higher scores always indicate stronger experienced barriers. Items were checked for missing values. For each respondent, the missing values were imputed with the average score of all respondents on all items in that scale, if at least $80 \%$ of the items of that scale had been completed by the respondent ${ }^{31}$. Descriptive statistics were performed to give an overview of the study sample and to check for outliers and floor and ceiling effects. An Exploratory Factor Analysis (EFA) assessed the construct validity. Principal axis factoring (PAF) with direct Oblimin (oblique) rotation was used to explore the structure of the scales. PAF was used since we attempted to identify latent constructs (factors) that could explain the pattern of item-item correlations, rather than decomposing the data into a set of linear variates to explain as much variance as possible, as in principal component analysis (PCA). The direct Oblimin technique was used to allow the factors to be correlated with each other. For the Kaiser-Meyer-Olkin measure of sampling adequacy we accepted a criterion of above $0.50^{32}$ and for the Bartlett's test of 
sphericity, we required significance at the $5 \%$ level, meaning rejection of the null hypothesis that all item-item correlations are zero ${ }^{33}$. The internal consistency was assessed in terms of Cronbach's Alpha ${ }^{34}$ and an item analysis was further performed by evaluating the corrected item-total correlations, based on a tentative criterion of 0.30 , as an acceptable correlation ${ }^{35}$.

\section{Results}

\section{Sample characteristics}

All the invited community care professionals $(\mathrm{N}=80)$ returned the questionnaire. Missing data of nine respondents for the MAINtAIN-C Behaviors were imputed (of whom six respondents had one missing item, and three respondents had two missing items). Missing data of 15 respondents for the MAINtAIN-C Barriers were imputed (of whom 9 respondents had 1 missing item, and 6 respondents had 2 missing items). One respondent had more than $20 \%$ missing on the Behaviors scale and was excluded from the analyses on the complete MAINtAIN-C scale. See Table 4.4 for an overview of the sample characteristics of the community care professionals $(\mathrm{N}=79)$.

Table 4.4 Sample characteristics of the community care professionals ( $N=79)$.

\begin{tabular}{|c|c|c|c|}
\hline & & $N$ & $\%$ \\
\hline Gender & Female & 77 & (97) \\
\hline \multirow[t]{3}{*}{ Profession } & Bachelor educated nurse & 7 & (9) \\
\hline & Vocationally educated nurse & 16 & (20) \\
\hline & Certified Nurse Assistant / Helping Aid / Nursing Student & 56 & (71) \\
\hline \multirow[t]{4}{*}{ Education } & Bachelor of Nursing & 8 & (10) \\
\hline & Vocational training & 23 & (29) \\
\hline & Secondary training & 48 & $(61)$ \\
\hline & & Median & Range [min-max] \\
\hline Age (years) & & 47.8 & $45.2[20-65]^{\mathrm{a}}$ \\
\hline Work experience (years) & & 18.0 & $40.6[1-42]^{b}$ \\
\hline Working hours/week & & 24.0 & $28.0[8-36]$ \\
\hline
\end{tabular}

${ }^{\text {a }}$ Based on $\mathrm{N}=78$, due to missing data. ${ }^{\mathrm{b}}$ Based on $\mathrm{N}=77$, due to missing data.

\section{Construct validity and internal consistency}

\section{Factor analysis for the MAINtAIN-C behaviors}

The EFA was carried out on the final MAINtAIN-C Behaviors questionnaire, which contained 20 items. This yielded a potential four-factor solution (eigenvalue $>1$ and scree plot; see Table S4.1, Additional File S4.1). Before rotation, the first factor accounted for $44 \%$ variance, the second for $13 \%$, the third for $7 \%$, and the fourth for $5 \%$, while all further factors each explained less than $5 \%$. After Oblimin rotation, no meaningful pattern in the loadings could be determined. Then, a three-factor solution 
was performed, and after Oblimin rotation, all the eight items containing the verbs, "I discuss" (items 5, 12-18), loaded strongly on factor 2 (F2) and much less on factor 1 (F1) and factor 3 (F3). The other 12 items loaded strongest either on F1 or on F3. No clear and interpretable pattern in the loadings on F1 and F3 could be determined. Furthermore, F1 and F3 correlated -0.46 with each other (see Table S4.1, Additional File S4.1). This suggested a two-factor solution. After Oblimin rotation, all items containing the verb, "I discuss," except item 18, loaded strongly on F2, all the other items loaded strongly on F1. Item 18 had nearly the same loading on F1 and F2. The factor-to-factor correlation was -0.495 (implying a positive correlation between the two item subsets, see the signs of the factor loadings in Table S4.1, Additional File S4.1. Therefore, we performed a reliability analysis on F1 (12 items) and F2 ( 8 items including item 18).

The Cronbach's alpha for internal consistency of F1 was .88, with item-total correlations for all items above 0.35. The Cronbach's alpha for F2 was 0.92, with item-total correlations for all items above 0.57 . The Pearson correlation between the mean scores on F1 and F2 was 0.61 , indicating a strong, positive relationship. Therefore, a singlefactor model was also performed (see Table 4.5).

The Cronbach's alpha of the total scale was 0.92, with item-total correlations ranging from 0.27 to 0.81 . The Kaiser-Meyer-Olkin measure of sampling adequacy was 0.87 and Bartlett's test of sphericity was significant $(p<0.05)$. We opt for a single-factor model, because of the strong positive correlation in the two-factor model, the good internal consistency of the single-factor model, and the theoretical fit of all the items in one scale. The sum score on this total scale for each respondent varying from 20 to 180, indicates the degree to which the respondent is perceived to encourage functional activities. See Additional File S4.2 for the complete MAINtAIN-C questionnaire. 
Table 4.5 Factor loadings after Oblimin rotation in the EFA* of the MAINtAIN-C scale (N=79).

\begin{tabular}{|c|c|c|c|c|}
\hline & \multirow{2}{*}{$\begin{array}{c}\text { MAINtAIN-C Behaviors } \\
\text { One-factor solution }\end{array}$} & \multicolumn{3}{|c|}{ MAINtAIN-C Barriers } \\
\hline & & \multicolumn{3}{|c|}{ Two-factor solution } \\
\hline \multirow[t]{2}{*}{ Items } & Factor 1 & Items & Factor 1 & Factor 2 \\
\hline & & Context of the clients & & \\
\hline 1 & 0.567 & 1 & 0.346 & -0.188 \\
\hline 2 & 0.652 & 2 & -0.060 & 0.556 \\
\hline 3 & 0.617 & 3 & 0.252 & -0.222 \\
\hline 4 & 0.671 & 4 & 0.329 & -0.103 \\
\hline 5 & 0.651 & 5 & -0.092 & 0.480 \\
\hline 6 & 0.647 & 6 & 0.139 & 0.699 \\
\hline 7 & 0.306 & 7 & 0.130 & 0.542 \\
\hline 8 & 0.737 & 8 & 0.026 & 0.656 \\
\hline 9 & 0.575 & 9 & 0.151 & 0.571 \\
\hline 10 & 0.440 & 10 & 0.075 & 0.569 \\
\hline 11 & 0.654 & Professional context & & \\
\hline 12 & 0.683 & 11 & 0.243 & -0.100 \\
\hline 13 & 0.682 & 12 & 0.402 & 0.080 \\
\hline 14 & 0.800 & 13 & 0.231 & -0.036 \\
\hline 15 & 0.838 & 14 & 0.385 & -0.065 \\
\hline 16 & 0.639 & 15 & 0.566 & 0.000 \\
\hline 17 & 0.690 & 16 & 0.116 & 0.109 \\
\hline 18 & 0.666 & 17 & 0.615 & 0.191 \\
\hline 19 & 0.686 & 18 & 0.421 & -0.047 \\
\hline \multirow[t]{21}{*}{20} & 0.384 & 19 & 0.288 & 0.030 \\
\hline & & 20 & 0.042 & -0.146 \\
\hline & & $\begin{array}{c}\text { Social context: the team } \\
\text { functioning }\end{array}$ & & \\
\hline & & 21 & 0.586 & 0.052 \\
\hline & & 22 & 0.696 & 0.216 \\
\hline & & 23 & 0.460 & 0.055 \\
\hline & & 24 & 0.235 & -0.180 \\
\hline & & 25 & 0.540 & 0.010 \\
\hline & & 26 & 0.509 & 0.207 \\
\hline & & Organizational context & & \\
\hline & & 27 & 0.594 & 0.068 \\
\hline & & 28 & 0.489 & 0.076 \\
\hline & & 29 & 0.378 & 0.040 \\
\hline & & 30 & 0.523 & -0.208 \\
\hline & & 31 & 0.202 & 0.036 \\
\hline & & 32 & 0.586 & 0.053 \\
\hline & & 33 & 0.455 & -0.024 \\
\hline & & Factor Correlations & & \\
\hline & & Factors & 1 & 2 \\
\hline & & 1 & 1 & -0.001 \\
\hline & & 2 & -0.001 & 1 \\
\hline
\end{tabular}

* The EFA was conducted using principal axis factoring and a direct Oblimin (oblique) rotation; factor loadings in boldface are the highest loading of that item. 


\section{Factor analysis for the MAINtAIN-C barriers}

The EFA carried out on the MAINtAIN-C Barriers questionnaire with 33 items, led to a 10 -factor solution according to the eigenvalue $>1$ criterion, but the scree-plot suggested four or possibly three factors. Before rotation, the first factor accounted for $18 \%$ variance, the second for $10 \%$, the third for $7 \%$, and the fourth for $5 \%$, while all further factors each explained less than $5 \%$. Therefore, both a four-factor solution and a three-factor solution were obtained. In both cases, after Oblimin rotation, no meaningful pattern in the loadings could be determined (see Table S4.2, Additional File S4.1).

Therefore, a two-factor solution was obtained and, after Oblimin rotation, 25 items loaded on F1, of which 22 items related to the professional, social, and organizational contexts. Eight items loaded on F2, of which 7 items were describing barriers related to the clients' context (see Table 4.5). Misfitting items were items 1, 3, and 4 (loaded stronger on F1, but are about the clients' context), item 20 (loaded stronger on F2, but is about the professional context) and item 16 (loaded less than 0.20 on F1 and almost equally high on both factors). The correlation between F1 and F2 was -0.001 .

We performed a reliability analysis on all items loading the highest on $F 1$, except the misfitting items 1, 3, 4, and 16 (see Table 4.5). This resulted in a scale of 21 items, with a Cronbach's alpha of 0.83 and item-total correlations ranging from 0.22 to 0.59 . We also performed a reliability analysis on all items loading highest on F2, except the misfitting item 20 (i.e., 7 items in total; see Table 4.5), which gave a Cronbach's alpha of 0.78 and item-total correlations ranging from 0.39 to 0.62 . The correlation between the mean scores on the two subscales (i.e., F1 and F2 without the misfitting items) was 0.10 , indicating a very weak to absent (linear) relationship.

To compare, we also computed correlations between the mean scores on the four predefined domains (i.e., factors related to the clients' context, as well as the professional, social, and organizational contexts). The correlations between the different contexts ranged from 0.16 (between the clients' context and the organizational context) to 0.61 (social and the organizational context). These correlations further supported the reduction to two subscales, one for the clients' context and one for the other three contexts.

We, therefore, opt for a two-factor solution with 7 items related to the clients' context, with good internal consistency (Cronbach's alpha: .78), and 21 items related to the professional, social, and organizational contexts, with good internal consistency (Cronbach's alpha: 0.83). The Kaiser-Meyer-Olkin measure of sampling adequacy for the two-factor solution was 0.58 and Bartlett's test of sphericity was significant $(p<0.05)$. The sum score per subscale--varying from 7 to 63 for the clients' context and from 21 to 189 for the professional, social, and organizational contexts, for each respondent-indicates the degree to which the respondent is perceived to experience barriers in stimulating functional activities. See Additional File 4.2 for the complete MAINTAIN-C questionnaire. 


\section{Discussion}

In the first phase of this study, the MAINtAIN questionnaire for the nursing home setting was adapted for the community care setting. This resulted in the MAINTAIN-C questionnaire, consisting of two scales to measure perceived behavior (20 items) and barriers (33 items) of community care professionals, in encouraging functional activities of clients in the community care setting. During the second phase, the construct validity and internal consistency of the MAINTAIN-C were assessed. This resulted in the Behaviors scale (20 items), which measures the perceived behavior of community care professionals in encouraging functional activities, showing good internal consistency (Cronbach's alpha: 0.92). The Barriers scale measures barriers in encouraging functional activities related to two dimensions: 1 ) the clients' context ( 7 items), with good internal consistency (Cronbach's alpha: 0.78); and 2) the professional, social, and organizational contexts (21 items), showing good internal consistency (Cronbach's alpha: 0.83 ).

Although no factor analysis had been performed in the original study in which the MAINtAIN was presented, we had expected that the initial theoretical clustering of the original MAINtAIN Behaviors (i.e., ADL, IADL, and general activities) would also be present in the adapted MAINtAIN-C questionnaire ${ }^{12,13}$. However, in the adapted MAINtAIN-C Behaviors scale, all items measured largely the same construct. It could be that the distinction between activities is more clear in nursing homes than in community care, since the care in nursing homes is primarily focuses on providing assistance in $\mathrm{ADL}^{36}$. It is likely that community care professionals interpret the encouragement of functional activities as all activities (i.e., ADL, IADL, and general activities) that directly take place at the clients' home. Only a distinction between the items with the verbs "I discuss," and the other items emerged, but the correlation between these two different factors was strong. One could argue that community care professionals might view the "I discuss" items differently, since these relate more to their direct personal behavior, than the other items.

For the adapted MAINtAIN-C Barriers scale, it was expected that the differences between the four domains (i.e., barriers related to the clients' context, as well as the professional, social, and organizational contexts) would emerge as in the initial theoretical clustering of the MAINtAIN ${ }^{14}$. Instead, two dimensions emerged, namely the clients' context versus the other three contexts. This contradicts other studies reporting that barriers often relate to various domains $s^{37,38}$. On the other hand, studies on promoting physical activity or function also report on barriers as a combination of

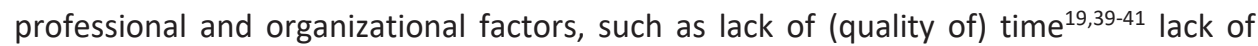
training and education ${ }^{40,41}$ and lack of protocols $s^{39,41}$ versus patient-related factors, such as lack of motivation of the patient ${ }^{19,40}$.

\section{Limitations}

This study has some methodological limitations. First, a modest sample size was used for conducting the EFA. Therefore, the statistical findings presented should be 
interpreted with caution and replicated in a larger sample. Next, only bacheloreducated community nurses were involved in the adaptation process during the first phase of the study, while community care professionals are the end users. However, the leading role of community nurses within community care might have warranted the inclusion of important behaviors and barriers. We also used a convenience sample of community care professionals to assess the content validity. Whether the results found in this study are generalizable to the community care setting at large remains to be demonstrated. The content validity of the MAINtAIN-C was assessed via a paper-based version of the questionnaire, while the construct validity and internal consistency were assessed via an online version of the MAINtAIN-C. This might have influenced the usability, but we tried to minimize this by providing clear instructions in the online program. Furthermore, the MAINtAIN-C questionnaire relies on self-reported data, which means that the reported perceived behavior may not necessarily be the same as their actual behavior in practice. Prior studies indicated, for example, that professionals in nursing homes perceive to encourage ADL often ${ }^{13}$, while observations indicate that the majority of residents are largely inactive during the day ${ }^{42}$. Although we tried to minimize bias by informing the respondents about the anonymous administration of the questionnaire, social desirability might have influenced the response.

\section{Implications}

The MAINtAIN-C is, to the best of our knowledge, the first questionnaire for assessing behavior and barriers of community care professionals in encouraging functional activities. The MAINtAIN-C can be used to provide insight into the behavior and barriers of community care professionals. Since these professionals are often used to perform functional activities on behalf of older adults, the MAINtAIN-C can be a useful learning instrument to display the possible difference between perceived and actual behavior in practice. Furthermore, insights on the perceived behavior and barriers of community care professionals in encouraging functional activities can be useful for researchers, managers, community nurses, and other community care professionals. Strategies to promote certain behavior and tackle the barriers can be implemented, to foster a change in behavior. Adopting these strategies within daily procedures and policies within community care, could eventually lead to increased or maintained functional activity among older adults living in the community.

\section{Conclusions}

The MAINtAIN-C seems promising to assess the behavior and barriers of community care professionals in encouraging functional activities. The results of this study also provide guidance for further research in a larger sample, to obtain more insight into the psychometric properties such as the ability of the MAINtAIN-C to measure changes in 
encouraging functional activity over time (responsiveness) and the degree of consistency of the MAINtAIN-C data obtained by the same rater (intra-rater reliability). 


\section{References}

1. World Health Organization. World report on ageing and health. Geneva: World Health Organization; 2015.

2. Plaisier I, Verbeek-Oudijk D, de Klerk M. Developments in home-care use. Policy and changing community-based care use by independent community- dwelling adults in the Netherlands. Health Policy. 2016;121(1):82-9.

3. Kempen GIJM, Doeglas DM, Suurmeijer TPMB: Groningen activity restriction scale (GARS): een handleiding. UMCG / Rijksuniversiteit Groningen, Research Institute SHARE 2012, Tweede herziene druk..

4. Albrecht GL, Snyder SL, Bickenbach J, Mitchell DT, Schalick WO. Encyclopedia of disability, vol. 1. Thousand Oaks, California: Sage; 2006.

5. Connolly D, Garvey J, McKee G. Factors associated with ADL/IADL disability in community dwelling older adults in the Irish longitudinal study on ageing (TILDA). Disabil Rehabil. 2017;39(8):809-16.

6. Genet N, Boerma W, Kroneman M, Hutchinson A, Saltman R: Home care across Europe: case studies. 2013.

7. Winkel A, Langberg H, Wæhrens EE. Reablement in a community setting. Disabil Rehabil. 2015;37(15):1347-52.

8. Resnick B, Galik E, Boltz M. Function focused care approaches: literature review of progress and future possibilities. J Am Med Dir Assoc. 2013;14(5):313-8.

9. Legg L, Gladman J, Drummond A, Davidson A. A systematic review of the evidence on home care reablement services. Clin Rehabil. 2016;30(8):741-9.

10. Aspinal F, Glasby J, Rostgaard T, Tuntland H, Westendorp RG. New horizons: Reablement-supporting older people towards independence. Age Ageing. 2016;45(5):574-8.

11. Whitehead PJ, Worthington EJ, Parry RH, Walker MF, Drummond AE. Interventions to reduce dependency in personal activities of daily living in community dwelling adults who use homecare services: a systematic review. Clin Rehabil. 2015;29(11):1064-76.

12. Kuk N, Zijlstra GAR, Bours GJJW, Hamers JPH, Kempen GIJM. Development and usability of the MAINtAIN, an inventory assessing nursing staff behavior to optimize and maintain functional activity among nursing home residents: a mixed-methods approach. BMC Health Serv Res. 2016;16:38.

13. Kuk N, den Ouden M, Zijlstra GAR, Hamers JPH, Kempen GIJM, Bours GJJW. Do nursing staff encourage functional activity among nursing home residents? A cross-sectional study of nursing staff perceived behaviors and associated factors. BMC Geriatr. 2017;17:18.

14. Kuk NO, Zijlstra GR, Bours GJ, Hamers JP, Tan FE, Kempen GI. Promoting functional activity among nursing home residents: a cross-sectional study on barriers experienced by nursing staff. J Aging Health. 2018;30(4):605-23.

15. Resnick B, Rogers V, Galik E, Gruber-Baldini AL. Measuring restorative care provided by nursing assistants: reliability and validity of the restorative care behavior checklist. Nurs Res. 2007;56(6): 387-98.

16. Resnick B, Gruber-Baldini AL, Zimmerman S, Galik E, Pretzer-Aboff I, Russ K, Hebel JR. Nursing home resident outcomes from the rescare intervention. J Am Geriatr Soc. 2009;57(7):1156-65.

17. Galik EM, Resnick B, Pretzer-Aboff I. 'Knowing what makes them tick': motivating cognitively impaired older adults to participate in restorative care. Int J Nurs Pract. 2009;15(1):48-55.

18. Resnick B, Simpson M, Galik E, Bercovitz A, Gruber-Baldini AL, Zimmerman S, Magaziner J. Making a difference: nursing assistants' perspectives of restorative care nursing. Rehabil Nurs. 2006;31(2):78-86.

19. Resnick B, Petzer-Aboff I, Galik E, Russ K, Cayo J, Simpson M, Zimmerman S. Barriers and benefits to implementing a restorative care intervention in nursing homes. J Am Med Dir Assoc. 2008;9(2):102-8.

20. Bulechek GM, Butcher HK, Dochterman JM, Wagner CM. Nursing Interventions Classification (NIC) (6th ed.). St. Louis: Elsevier Mosby; 2013.

21. Fleuren MAH, Paulussen TGWM, Van Dommelen $P$, Van Buuren $S$. Towards a measurement instrument for determinants of innovations. Int J Qual Health Care. 2014;26(5):501-10.

22. Wysocki A, Butler M, Kane RL, Kane RA, Shippee T, Sainfort F. Long-term services and supports for older adults: a review of home and community- based services versus institutional care. J Aging Soc Policy. 2015;27(3):255-79. 
23. Beaton DE, Bombardier C, Guillemin F, Ferraz MB. Guidelines for the process of cross-cultural adaptation of self-report measures. Spine. 2000;25(24):3186-91.

24. Kempen GIJM, Miedema I, Ormel J, Molenaar W. The assessment of disability with the Groningen activity restriction scale. Conceptual framework and psychometric properties. Soc Sci Med. 1996;43(11):1601-10.

25. Kempen GIJM, Steverink N, Ormel J, Deeg DJH. The assessment of ADL among frail elderly in an interview survey: self-report versus performance- based tests and determinants of discrepancies. J Gerontol Ser B Psychol Sci Soc Sci. 1996;51(5):P254-60.

26. Mokkink LB, Terwee CB, Patrick DL, Alonso J, Stratford PW, Knol DL, Bouter LM, de Vet HCW. The COSMIN checklist for assessing the methodological quality of studies on measurement properties of health status measurement instruments: an international Delphi study. Qual Life Res. 2010;19(4): 539-49.

27. Proctor E, Silmere H, Raghavan R, Hovmand P, Aarons G, Bunger A, Griffey R, Hensley M. Outcomes for implementation research: conceptual distinctions, measurement challenges, and research agenda. Adm Policy Ment Health Ment Health Serv Res. 2011;38(2):65-76.

28. Flick U. An introduction to qualitative research. Thousand Oaks, California: Sage Publications Limited; 2009.

29. Polit DF, Beck CT. Nursing research : generating and assessing evidence for nursing practice. Philadelphia: Wolters Kluwer Health/Lippincott Williams \& Wilkins; 2012.

30. IBM. IBM SPSS Statistics for Windows, Version Q3 25.0. Armonk, NY: IBM Corp; 2017.

31. Béland S, Pichette F, Jolani S. Impact on Cronbach's $\alpha$ of simple treatment methods for missing data. Quant Methods Psychol. 2016;12(1):57-73.

32. Kaiser HF. An index of factorial simplicity. Psychometrika. 1974;39(1):31-6.

33. Field A. Discovering statistics using IBM SPSS Statistics. 4th ed. London: SAGE Publication Lda; 2013.

34. Cronbach LJ. Coefficient alpha and the internal structure of tests. Psychometrika. 1951;16(3):297-334.

35. Nunnally JC, Bernstein IH. Psychometric theory. 3rd ed. New York: McGraw- Hill; 1994.

36. Blair CE, Glaister J, Brown A, Phillips C. Fostering activities of daily living by intact nursing home residents. Educ Gerontol. 2007;33(8):679-99.

37. Grol R, Wensing M. What drives change? Barriers to and incentives for achieving evidence-based practice. Med J Aust. 2004;180(S6):S57-60.

38. Benjamin K, Edwards N, Ploeg J, Legault F. Barriers to physical activity and restorative care for residents in long-term care: a review of the literature. J Aging Phys Act. 2014;22(1):154-65.

39. McDowell N, McKenna J, Naylor P. Factors that influence practice nurses to promote physical activity. $\mathrm{Br}$ J Sports Med. 1997;31(4):308-13.

40. Huijg JM, Gebhardt WA, Verheijden MW, van der Zouwe N, de Vries JD, Middelkoop BJ, Crone MR. Factors influencing primary health care professionals' physical activity promotion behaviors: a systematic review. Int J Behav Med. 2015;22(1):32-50.

41. Ribera AP, McKenna J, Riddoch C. Attitudes and practices of physicians and nurses regarding physical activity promotion in the Catalan primary health- care system. Eur J Public Health. 2005;15(6):569-75.

42. den Ouden M, Bleijlevens MH, Meijers JM, Zwakhalen SM, Braun SM, Tan FE, Hamers JP. Daily (in) activities of nursing home residents in their wards: an observation study. J Am Med Dir Assoc. 2015;16(11):963-8. 


\section{Supplementary information}

\section{Additional File: S4.1}

Table S4.1 and Table S4.2 show the complete factor loadings on the MAINtAIN-C Behaviors and Barriers scales.

Table S4.1 Factor loadings after Oblimin rotation in the EFA of the MAINtAIN-C Behaviors scale ( $N=79)$.

\begin{tabular}{|c|c|c|c|c|c|c|c|c|c|}
\hline \multirow[t]{2}{*}{ Items } & \multicolumn{4}{|c|}{ Four factors } & \multicolumn{3}{|c|}{ Three factors } & \multicolumn{2}{|c|}{ Two factors } \\
\hline & 1 & 2 & 3 & 4 & 1 & 2 & 3 & 1 & 2 \\
\hline 1 & .246 & -.118 & -.360 & .084 & .288 & -.127 & -.353 & .566 & -.090 \\
\hline 2 & .133 & .023 & -.743 & .131 & .249 & -.003 & -.715 & .825 & .056 \\
\hline 3 & -.200 & -.152 & -.834 & .082 & -.016 & -.195 & -.704 & .579 & -.135 \\
\hline 4 & .061 & -.210 & -.377 & .359 & .373 & -.231 & -.276 & .575 & -.200 \\
\hline 5 & -.050 & -.749 & .095 & .255 & .156 & -.755 & .168 & -.001 & -.763 \\
\hline 6 & .498 & .011 & -.247 & .313 & .689 & .015 & -.221 & .796 & .034 \\
\hline 7 & .053 & .018 & .031 & .621 & .515 & .003 & .120 & .342 & -.011 \\
\hline 8 & .103 & -.214 & -.419 & .369 & .415 & -.236 & -.320 & .650 & -.202 \\
\hline 9 & .369 & -.297 & -.005 & .139 & .412 & -.294 & -.006 & .371 & -.290 \\
\hline 10 & .445 & .123 & -.271 & .117 & .476 & .124 & -.284 & .674 & .157 \\
\hline 11 & .547 & -.008 & -.206 & .288 & .711 & -.002 & -.185 & .780 & .012 \\
\hline 12 & -.192 & -.857 & -.084 & .083 & -.097 & -.874 & -.021 & -.064 & -.872 \\
\hline 13 & -.191 & -.958 & -.062 & -.044 & -.220 & -.985 & -.031 & -.159 & -.975 \\
\hline 14 & .082 & -.770 & -.127 & .006 & .052 & -.791 & -.117 & .151 & -.779 \\
\hline 15 & .182 & -.786 & -.147 & -.101 & .039 & -.801 & -.174 & .191 & -.781 \\
\hline 16 & .119 & -.767 & .075 & -.057 & .015 & -.776 & .055 & -.032 & -.781 \\
\hline 17 & .400 & -.545 & .003 & -.071 & .232 & -.540 & -.060 & .262 & -.531 \\
\hline 18 & .420 & -.422 & -.156 & -.163 & .191 & -.420 & -.224 & .369 & -.395 \\
\hline 19 & .386 & -.322 & -.006 & .297 & .561 & -.320 & .027 & .469 & -.318 \\
\hline 20 & .099 & .049 & -.664 & -.210 & -.068 & .025 & -.699 & .520 & .073 \\
\hline \multicolumn{10}{|c|}{ Factor Correlations } \\
\hline Factors & 1 & 2 & 3 & 4 & 1 & 2 & 3 & 1 & 2 \\
\hline 1 & 1 & -.33 & -.47 & .30 & 1 & -.43 & -.46 & 1 & -.495 \\
\hline 2 & -.33 & 1 & .37 & -.28 & -.43 & 1 & .34 & -.495 & 1 \\
\hline 3 & -.47 & .37 & 1 & -.27 & -.46 & .34 & 1 & & \\
\hline 4 & .30 & -.28 & -.27 & 1 & & & & & \\
\hline
\end{tabular}

*The EFA was conducted using principal axis factoring and a direct Oblimin (oblique) rotation; factor loadings in boldface are the highest loading of that item. 
Table S4.2 Factor loadings after Oblimin rotation in the EFA of the MAINtAIN-C Barriers scale $(N=79)$.

\begin{tabular}{|c|c|c|c|c|c|c|c|}
\hline \multirow{2}{*}{$\frac{\text { Items }}{\text { Items co }}$} & \multicolumn{4}{|c|}{ Four factors } & \multicolumn{3}{|c|}{ Three factors } \\
\hline & \multirow{2}{*}{ 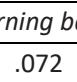 } & \multirow{2}{*}{$\frac{\text { riers re }}{-.059}$} & \multirow{2}{*}{$\frac{d \text { to the }}{.263}$} & \multirow{2}{*}{$\frac{t \text { of the }}{.409}$} & \multirow[b]{2}{*}{.176} & \multirow[b]{2}{*}{-.189} & \multirow[b]{2}{*}{.290} \\
\hline 1 & & & & & & & \\
\hline 2 & .006 & .475 & -.044 & -.247 & -.010 & .553 & -.079 \\
\hline 3 & .218 & -.124 & -.062 & .287 & .289 & -.228 & -.030 \\
\hline 4 & .359 & -.023 & -.136 & .235 & .427 & -.115 & -.108 \\
\hline 5 & -.116 & .360 & .191 & -.387 & -.195 & .496 & .144 \\
\hline 6 & .204 & .606 & -.021 & -.281 & .189 & .695 & -.058 \\
\hline 7 & .023 & .685 & -.061 & .231 & .178 & .538 & -.058 \\
\hline 8 & -.014 & .705 & -.072 & .036 & .090 & .651 & -.091 \\
\hline 9 & .070 & .604 & .028 & .034 & .154 & .567 & .013 \\
\hline 10 & -.027 & .475 & .283 & -.323 & -.082 & .592 & .242 \\
\hline \multicolumn{8}{|c|}{ Items concerning barriers related to the professional context } \\
\hline 11 & -.048 & -.121 & .512 & .032 & -.082 & -.099 & .525 \\
\hline 12 & .102 & .089 & .487 & .072 & .106 & .089 & .499 \\
\hline 13 & -.140 & .009 & .532 & .182 & -.107 & -.029 & .543 \\
\hline 14 & .476 & -.072 & -.091 & .014 & .467 & -.074 & -.077 \\
\hline 15 & .573 & -.015 & .055 & .010 & .559 & -.006 & .073 \\
\hline 16 & -.085 & .065 & .382 & -.087 & -.126 & .120 & .377 \\
\hline 17 & .783 & .133 & -.103 & -.141 & .733 & .187 & -.092 \\
\hline 18 & .064 & .050 & .445 & .325 & .149 & -.046 & .463 \\
\hline 19 & .063 & .169 & .151 & .379 & .191 & .027 & .173 \\
\hline 20 & -.042 & -.050 & -.004 & .258 & .034 & -.147 & .016 \\
\hline \multicolumn{8}{|c|}{ Items concerning barriers related to the social context: team functioning } \\
\hline 21 & .459 & .127 & .114 & .238 & .532 & .045 & .141 \\
\hline 22 & .810 & .227 & -.123 & .034 & .842 & .212 & -.111 \\
\hline 23 & .298 & .124 & .169 & .208 & .363 & .054 & .189 \\
\hline 24 & .145 & -.264 & .305 & -.141 & .049 & -.177 & .303 \\
\hline 25 & .657 & -.023 & -.081 & -.039 & .629 & -.001 & -.065 \\
\hline 26 & .306 & .274 & .224 & .203 & .384 & .204 & .237 \\
\hline \multicolumn{8}{|c|}{ Items concerning barriers related to the organizational context } \\
\hline 27 & .430 & -.036 & .483 & -.191 & .330 & .073 & .467 \\
\hline 28 & .397 & .092 & .141 & .082 & .418 & .073 & .156 \\
\hline 29 & .373 & -.026 & .135 & -.132 & .310 & .039 & .136 \\
\hline 30 & .468 & -.239 & .189 & .001 & .416 & -.211 & .210 \\
\hline 31 & .101 & .000 & .227 & -.066 & .067 & .040 & .224 \\
\hline 32 & .519 & .050 & .140 & .041 & .521 & .049 & .155 \\
\hline 33 & .162 & -.023 & .499 & .078 & .153 & -.020 & .517 \\
\hline \multicolumn{8}{|c|}{ Factor-Factor correlations } \\
\hline Factors & 1 & 2 & 3 & 4 & 1 & 2 & 3 \\
\hline 1 & 1 & .07 & .28 & .19 & 1 & -.02 & .30 \\
\hline 2 & .07 & 1 & .07 & -.11 & -.02 & 1 & .04 \\
\hline 3 & .28 & .07 & 1 & .04 & .30 & .04 & 1 \\
\hline 4 & .19 & -.11 & .04 & 1 & & & \\
\hline
\end{tabular}

*The EFA was conducted using principal axis factoring and a direct Oblimin (oblique) rotation; factor loadings are bolded as they represent the items that most contribute towards the respective factors. 


\section{Additional File S4.2}

\section{MAINtAIN-C questionnaire}

The MAINtAIN-C questionnaire consists of the MAINtAIN-C Behaviors scale to measure the perceived behavior in encouraging functional activities (20 items) and the MAINtAIN-C Barriers scale to measure the perceived barriers in encouraging functional activities related to the clients' context ( 7 items) and the professional, social, and organizational contexts (21 items), of community care professionals. To ensure transparency and comparability in the interpretation and analysis of the questionnaire, a description is provided on how to interpret the results and how the missing values can be handled.

\section{Interpretation of the MAINtAIN-C Behaviors}

The sum score on the total scale, for each respondent varying from 20 to 180 , indicates the degree to which the respondent perceives to encourage functional activities.

\section{Interpretation of the MAINTAIN-C Barriers}

The scores of the positively formulated items should be reversed so that higher scores always indicate stronger experienced barriers. Furthermore, the sum score per subscale-varying from 7 to 63 for the clients' context and from 21 to 189 for the professional, social, and organizational contexts, for each respondent-indicates the degree to which the respondent is perceived to experience barriers in encouraging functional activities.

\section{Handling the missing values of the MAINTAIN-C}

To ensure comparability and transparency in scores, the average score of all respondents on all items in that scale can be imputed, if at least $80 \%$ of the items of that scale had been completed by the respondent. 


\section{MAINtAIN-C Behaviors}

\begin{tabular}{|c|c|c|c|c|c|c|c|c|c|c|}
\hline 1. & $\begin{array}{l}\text { Iclosely follow the extent to } \\
\text { which clients are able to } \\
\text { perform their own ADLs. }\end{array}$ & $\begin{array}{c}\text { Never } \\
0\end{array}$ & 0 & 0 & 0 & $\begin{array}{c}\text { Sometimes } \\
0\end{array}$ & 0 & 0 & 0 & $\begin{array}{c}\text { Always } \\
0\end{array}$ \\
\hline 2. & $\begin{array}{l}\text { Iencourage clients to } \\
\text { perform their aWn ADLs as } \\
\text { much as possible. }\end{array}$ & $\begin{array}{c}\text { Never } \\
0\end{array}$ & 0 & 0 & 0 & $\begin{array}{c}\text { Sometimes } \\
0\end{array}$ & 0 & 0 & 0 & $\begin{array}{c}\text { Always } \\
0\end{array}$ \\
\hline 3. & $\begin{array}{l}\text { I closely follow the extent to } \\
\text { which assistive devices are } \\
\text { available and adequately } \\
\text { used by clients. }\end{array}$ & $\begin{array}{c}\text { Never } \\
0\end{array}$ & 0 & 0 & 0 & $\begin{array}{c}\text { Sometimes } \\
0\end{array}$ & 0 & 0 & 0 & $\begin{array}{c}\text { Always } \\
0\end{array}$ \\
\hline 4. & $\begin{array}{l}1 \text { advise clients about the } \\
\text { added value of consulting } \\
\text { other disciplines (for } \\
\text { example physical therapy) } \\
\text { in order to encourage the } \\
\text { independent performance } \\
\text { of ADLs. }\end{array}$ & $\begin{array}{c}\text { Never } \\
0\end{array}$ & $Q$ & 0 & 0 & Sometimes & $Q$ & 0 & 0 & $\begin{array}{c}\text { Always } \\
\text { O }\end{array}$ \\
\hline 5. & $\begin{array}{l}\text { I discuss with new clients if a } \\
\text { meal can be eaten } \\
\text { independently. }\end{array}$ & $\begin{array}{c}\text { Never } \\
0\end{array}$ & 0 & 0 & 0 & $\begin{array}{c}\text { Sometimes } \\
0\end{array}$ & 0 & 0 & 0 & $\begin{array}{c}\text { Always } \\
0\end{array}$ \\
\hline 6. & $\begin{array}{l}\text { I encourage clients to } \\
\text { independently dress and } \\
\text { undress. }\end{array}$ & $\begin{array}{c}\text { Never } \\
0\end{array}$ & 0 & 0 & 0 & $\begin{array}{c}\text { Sometimes } \\
0\end{array}$ & $Q$ & 0 & 0 & $\begin{array}{c}\text { Always } \\
0\end{array}$ \\
\hline 7. & $\begin{array}{l}\text { I complement clients when } \\
\text { they dress and undress } \\
\text { themselves. }\end{array}$ & $\begin{array}{c}\text { Never } \\
Q\end{array}$ & 0 & $\mathrm{O}$ & 0 & $\begin{array}{c}\text { Sometimes } \\
0\end{array}$ & 0 & $\mathrm{Q}$ & 0 & $\begin{array}{c}\text { Always } \\
0\end{array}$ \\
\hline B. & $\begin{array}{l}\text { I closely follow the extent to } \\
\text { which clients are to move } \\
\text { about within their home. }\end{array}$ & $\begin{array}{c}\text { Never } \\
0\end{array}$ & 0 & 0 & Q & $\begin{array}{c}\text { Sometimes } \\
\text { (1) }\end{array}$ & 0 & 0 & $Q$ & $\begin{array}{l}\text { Always } \\
0\end{array}$ \\
\hline 9. & $\begin{array}{l}\text { I encourage clients to } \\
\text { participate in activities } \\
\text { outside their home. }\end{array}$ & $\begin{array}{c}\text { Never } \\
0\end{array}$ & 0 & 0 & 0 & $\begin{array}{c}\text { Sometimes } \\
0\end{array}$ & 0 & 0 & 0 & $\begin{array}{c}\text { Always } \\
0\end{array}$ \\
\hline 10. & $\begin{array}{l}\text { I encourage clients to } \\
\text { independently wash and dry } \\
\text { themselves. }\end{array}$ & $\begin{array}{c}\text { Never } \\
0\end{array}$ & 0 & $Q$ & 0 & $\begin{array}{c}\text { Sometimes } \\
0\end{array}$ & 0 & 0 & 0 & $\begin{array}{c}\text { Always } \\
0\end{array}$ \\
\hline 11. & $\begin{array}{l}\text { I encourage clients to use } \\
\text { the toilet independently. }\end{array}$ & $\begin{array}{c}\text { Never } \\
Q\end{array}$ & 0 & 0 & 0 & $\begin{array}{c}\text { Sometimes } \\
0\end{array}$ & 0 & 0 & 0 & $\begin{array}{c}\text { Always } \\
0\end{array}$ \\
\hline
\end{tabular}




\begin{tabular}{|c|c|c|c|c|c|c|c|c|c|c|}
\hline 12. & $\begin{array}{l}\text { I discuss with dients if they } \\
\text { can prepare their meals } \\
\text { independently. }\end{array}$ & $\begin{array}{c}\text { Never } \\
0\end{array}$ & 0 & 0 & 0 & Sornetimes & 0 & $O$ & 0 & $\begin{array}{c}\text { Always } \\
0\end{array}$ \\
\hline 13. & $\begin{array}{l}\text { I discuss with clients if they } \\
\text { can do their shopping } \\
\text { independently. }\end{array}$ & $\begin{array}{c}\text { Never } \\
0\end{array}$ & 0 & 0 & 0 & $\begin{array}{c}\text { Sometimes } \\
0\end{array}$ & $Q$ & 0 & 0 & $\begin{array}{c}\text { Always } \\
0\end{array}$ \\
\hline 14. & $\begin{array}{l}1 \text { discuss with clients if they } \\
\text { can wash their clothes } \\
\text { independently. }\end{array}$ & $\begin{array}{c}\text { Never } \\
\mathrm{O}\end{array}$ & 0 & 0 & 0 & $\begin{array}{c}\text { Sometimes } \\
0\end{array}$ & 0 & 0 & 0 & $\begin{array}{c}\text { Always } \\
Q\end{array}$ \\
\hline 15. & $\begin{array}{l}\text { I discuss with clients if they } \\
\text { can do 'light housework' } \\
\text { independently, for example } \\
\text { washing/drying dishes. }\end{array}$ & $\begin{array}{c}\text { Never } \\
0\end{array}$ & 0 & 0 & 0 & $\begin{array}{c}\text { Sometimes } \\
0\end{array}$ & 0 & 0 & 0 & $\begin{array}{c}\text { Always } \\
0\end{array}$ \\
\hline 16. & $\begin{array}{l}\text { I discuss with clients if they } \\
\text { can mop the bathroom } \\
\text { independently after getting } \\
\text { washed. }\end{array}$ & $\begin{array}{c}\text { Never } \\
0\end{array}$ & 0 & 0 & 0 & $\begin{array}{c}\text { Sometimes } \\
0\end{array}$ & 0 & 0 & 0 & $\begin{array}{c}\text { Always } \\
0\end{array}$ \\
\hline 17. & $\begin{array}{l}\text { I discuss with clients which } \\
\text { activities they used to do } \\
\text { and they still can perform } \\
\text { (ADLs, IADLs, social } \\
\text { activities). }\end{array}$ & $\begin{array}{c}\text { Never } \\
0\end{array}$ & 0 & 0 & 0 & $\begin{array}{c}\text { Sometimes } \\
0\end{array}$ & 0 & 0 & 0 & $\begin{array}{c}\text { Always } \\
0\end{array}$ \\
\hline 18. & $\begin{array}{l}\text { I discuss with clients which } \\
\text { activities (ADLs, IADLs, } \\
\text { social activities) they would } \\
\text { really like to perform } \\
\text { themselves. }\end{array}$ & $\begin{array}{c}\text { Never } \\
0\end{array}$ & 0 & 0 & 0 & $\begin{array}{c}\text { Sornetimes } \\
0\end{array}$ & 0 & 0 & 0 & $\begin{array}{c}\text { Always } \\
0\end{array}$ \\
\hline 19. & $\begin{array}{l}\text { I encourage the clients' } \\
\text { family and informal } \\
\text { caregivers to promote self- } \\
\text { reliance in clients. }\end{array}$ & $\begin{array}{c}\text { Never } \\
0\end{array}$ & 0 & 0 & 0 & $\begin{array}{c}\text { Sometimes } \\
0\end{array}$ & 0 & 0 & 0 & $\begin{array}{c}\text { Always } \\
0\end{array}$ \\
\hline 20. & $\begin{array}{l}\text { If 'encourage self-reliance } \\
\text { and independence' is } \\
\text { included in the care plan, } \\
\text { then I follow this. }\end{array}$ & $\begin{array}{c}\text { Never } \\
0\end{array}$ & 0 & 0 & 0 & $\begin{array}{c}\text { Sometimes } \\
\text { O }\end{array}$ & 0 & 0 & 0 & $\begin{array}{c}\text { Always } \\
0\end{array}$ \\
\hline
\end{tabular}




\section{MAINtAIN-C Barriers}

\section{Context of the clients}

\begin{tabular}{|c|c|c|c|c|c|c|c|c|c|c|}
\hline 1. & $\begin{array}{l}\text { Clients are often able to } \\
\text { perform ADLs more } \\
\text { independently than they } \\
\text { now do. }\end{array}$ & $\begin{array}{l}\text { Completely } \\
\text { disagree } \\
0\end{array}$ & ly & 0 & 0 & $\begin{array}{c}\text { Neither agree, } \\
\text { nor disagree } \\
\bigcirc\end{array}$ & 0 & 0 & 0 & $\begin{array}{l}\text { Completely } \\
\text { agree } \\
\bigcirc\end{array}$ \\
\hline 2. & $\begin{array}{l}\text { Clients are afraid to walk on } \\
\text { their own, without help } \\
\text { from others. }\end{array}$ & $\begin{array}{c}\text { Never } \\
\bigcirc\end{array}$ & 0 & 0 & 0 & $\begin{array}{c}\text { Sometimes } \\
0\end{array}$ & 0 & 0 & 0 & $\begin{array}{c}\text { Always } \\
0\end{array}$ \\
\hline 3. & $\begin{array}{l}\text { Clients ask for help with } \\
\text { ADLs so that they can get } \\
\text { extra attention. }\end{array}$ & $\begin{array}{c}\text { Never } \\
\mathrm{O}\end{array}$ & 0 & 0 & 0 & Sometimes & 0 & 0 & 0 & $\begin{array}{c}\text { Always } \\
0\end{array}$ \\
\hline 4. & $\begin{array}{l}\text { Family or informal } \\
\text { caregivers expect the } \\
\text { nurses and nurse assistants } \\
\text { to take over the activities } \\
\text { that clients themselves can } \\
\text { still perform. }\end{array}$ & $\begin{array}{c}\text { Never } \\
0\end{array}$ & 0 & 0 & 0 & $\begin{array}{c}\text { Sometimes } \\
0\end{array}$ & 0 & 0 & 0 & $\begin{array}{c}\text { Always } \\
\mathrm{O}\end{array}$ \\
\hline 5. & $\begin{array}{l}\text { Clients do not want to } \\
\text { perform activities } \\
\text { themselves such as bathing } \\
\text { or opening/closing curtains } \\
\text { even if they still can. }\end{array}$ & $\begin{array}{c}\text { Never } \\
0\end{array}$ & 0 & 0 & 0 & Sometimes & 0 & 0 & 0 & $\begin{array}{c}\text { Always } \\
0\end{array}$ \\
\hline 6. & $\begin{array}{l}\text { Financial limitations restrict } \\
\text { clients in performing } A D L s \\
\text { and } I A D L 5 \text { independently. }\end{array}$ & $\begin{array}{c}\text { Never } \\
0\end{array}$ & 0 & 0 & 0 & $\begin{array}{c}\text { Sometimes } \\
0\end{array}$ & 0 & 0 & b & $\begin{array}{c}\text { Always } \\
0\end{array}$ \\
\hline 7. & $\begin{array}{l}\text { An overburdened family or } \\
\text { informal caregiver limits } \\
\text { clients in performing } A D L s \\
\text { and IADLs independently }\end{array}$ & $\begin{array}{c}\text { Never } \\
\mathrm{O}\end{array}$ & 0 & 0 & 0 & $\begin{array}{c}\text { Sometimes } \\
0\end{array}$ & 0 & 0 & 0 & $\begin{array}{c}\text { Always } \\
0\end{array}$ \\
\hline
\end{tabular}




\section{Context of the professionals, the social context (the team functioning) and the organizational context.}

\begin{tabular}{|c|c|c|c|c|c|c|c|c|c|c|}
\hline 1. & $\begin{array}{l}\text { I think that organizing my } \\
\text { work so that clients are } \\
\text { ready on time is more } \\
\text { important than clients } \\
\text { performing ADLs } \\
\text { independently. }\end{array}$ & $\begin{array}{c}\text { Never } \\
0\end{array}$ & $a$ & 0 & 0 & $\begin{array}{c}\text { Sometimes } \\
0\end{array}$ & 0 & 0 & 0 & $\begin{array}{c}\text { Always } \\
0\end{array}$ \\
\hline 2. & $\begin{array}{l}\text { I am afraid that clients will } \\
\text { hurt themselves if I } \\
\text { encourage them to walk } \\
\text { alone. }\end{array}$ & $\begin{array}{c}\text { Never } \\
0\end{array}$ & 0 & 0 & 0 & Sometimes & 0 & 0 & 0 & $\begin{array}{c}\text { Always } \\
0\end{array}$ \\
\hline 3. & $\begin{array}{l}\text { It is primarily the } \\
\text { responsibility of the } \\
\text { physical therapist or } \\
\text { occupational therapist to } \\
\text { encourage clients to } \\
\text { perform activities. }\end{array}$ & $\begin{array}{l}\text { Completely } \\
\text { disagree } \\
\mathrm{Q}\end{array}$ & O & $Q$ & 0 & $\begin{array}{c}\text { Neither agree, } \\
\text { nor disagree } \\
0\end{array}$ & $Q$ & $Q$ & 0 & $\begin{array}{c}\text { Completely } \\
\text { agree } \\
\text { D }\end{array}$ \\
\hline 4. & $\begin{array}{l}\text { Within my team, we think } \\
\text { that it is important to } \\
\text { encourage clients to } \\
\text { perform ADLs as much as } \\
\text { possible independently. }\end{array}$ & $\begin{array}{l}\text { Completely } \\
\text { disagree } \\
0\end{array}$ & y & 0 & 0 & $\begin{array}{c}\text { Neither agree, } \\
\text { nor disagree } \\
\mathrm{O}\end{array}$ & 0 & 0 & 0 & $\begin{array}{c}\text { Completely } \\
\text { agree } \\
0\end{array}$ \\
\hline 5. & $\begin{array}{l}\text { Within my team, we think } \\
\text { that it is our task to inform } \\
\text { the family or informal } \\
\text { caregivers about the } \\
\text { importance of clients } \\
\text { performing activities } \\
\text { independently. }\end{array}$ & $\begin{array}{l}\text { Completely } \\
\text { disagree } \\
0\end{array}$ & Q & 0 & 0 & $\begin{array}{c}\text { Neither agree, } \\
\text { nor disagree } \\
\bigcirc\end{array}$ & 0 & 0 & 0 & $\begin{array}{c}\text { Completely } \\
\text { agree } \\
0\end{array}$ \\
\hline 6. & $\begin{array}{l}\text { Within my team, sufficient } \\
\text { expertise is available to } \\
\text { encourage clients to be as } \\
\text { independent as possible in } \\
\text { performing ADLs (such as } \\
\text { bathing, moving about). }\end{array}$ & $\begin{array}{l}\text { Completely } \\
\text { disagree } \\
0\end{array}$ & y & 0 & 0 & $\begin{array}{c}\text { Neither agree, } \\
\text { nor disagree } \\
0\end{array}$ & 0 & 0 & 0 & $\begin{array}{c}\text { Completely } \\
\text { agree } \\
\bigcirc\end{array}$ \\
\hline 7. & $\begin{array}{l}\text { Encouraging independence } \\
\text { as much as possible in } \\
\text { clients' ADLs, IADLs and } \\
\text { social activities gives me } \\
\text { less time for other things. }\end{array}$ & $\begin{array}{l}\text { Completely } \\
\text { disagree } \\
Q\end{array}$ & o & 0 & 0 & $\begin{array}{c}\text { Neither agree, } \\
\text { nor disagree } \\
0\end{array}$ & 0 & 0 & 0 & $\begin{array}{c}\text { Completely } \\
\text { agree } \\
\bigcirc\end{array}$ \\
\hline 8. & $\begin{array}{l}\text { I find it difficult to } \\
\text { encourage clients to be } \\
\text { self-reliant and } \\
\text { independent. }\end{array}$ & $\begin{array}{l}\text { Completely } \\
\text { disagree } \\
0\end{array}$ & O & 0 & $\mathrm{O}$ & $\begin{array}{c}\text { Neither agree, } \\
\text { nor disagree } \\
Q\end{array}$ & 0 & 0 & 0 & $\begin{array}{c}\text { Completely } \\
\text { agree } \\
0\end{array}$ \\
\hline
\end{tabular}




\begin{tabular}{|c|c|c|c|c|c|c|c|c|c|c|}
\hline 9. & $\begin{array}{l}\text { Within my team, the } \\
\text { collaboration with experts } \\
\text { (for example occupational } \\
\text { or physical therapists) is not } \\
\text { good enough to encourage } \\
\text { clients in performing ADLs } \\
\text { as independently as } \\
\text { possible. }\end{array}$ & $\begin{array}{l}\text { Completely } \\
\text { disagree } \\
0\end{array}$ & 0 & 0 & 0 & $\begin{array}{c}\text { Neither agree, } \\
\text { nor disagree } \\
\text { O }\end{array}$ & 0 & 0 & 0 & $\begin{array}{c}\text { Completely } \\
\text { agree } \\
0\end{array}$ \\
\hline 10. & $\begin{array}{l}\text { I can count on enough } \\
\text { support from my colleagues } \\
\text { when I allow clients to } \\
\text { perform ADLs and IADLs as } \\
\text { independently as possible. }\end{array}$ & $\begin{array}{l}\text { Completely } \\
\text { disagree } \\
0\end{array}$ & & 0 & 0 & $\begin{array}{c}\text { Neither agree, } \\
\text { nor disagree } \\
0\end{array}$ & 0 & 0 & 0 & $\begin{array}{c}\text { Completely } \\
\text { agree } \\
0\end{array}$ \\
\hline 11. & $\begin{array}{l}\text { The manager of my team } \\
\text { considers it important that } \\
\text { clients perform ADLs and } \\
\text { IADLs as independently as } \\
\text { possible. }\end{array}$ & $\begin{array}{c}\text { Never } \\
0\end{array}$ & 0 & 0 & 0 & $\begin{array}{c}\text { Sometimes } \\
0\end{array}$ & 0 & 0 & 0 & $\begin{array}{c}\text { Always } \\
0\end{array}$ \\
\hline 12. & $\begin{array}{l}\text { I speak to my colleagues } \\
\text { when I hear that they } \\
\text { perform activities that } \\
\text { clients can still perform } \\
\text { themselves. }\end{array}$ & $\begin{array}{c}\text { Never } \\
0\end{array}$ & 0 & 0 & 0 & $\begin{array}{c}\text { Sometimes } \\
0\end{array}$ & 0 & 0 & 0 & $\begin{array}{c}\text { Always } \\
0\end{array}$ \\
\hline 13. & $\begin{array}{l}\text { The team discusses how we } \\
\text { can encourage clients to } \\
\text { perform ADLs and IADLs as } \\
\text { independently as possible. }\end{array}$ & $\begin{array}{c}\text { Never } \\
0\end{array}$ & 0 & 0 & 0 & $\begin{array}{c}\text { Sometimes } \\
0\end{array}$ & 0 & 0 & 0 & $\begin{array}{c}\text { Always } \\
0\end{array}$ \\
\hline 14. & $\begin{array}{l}\text { Within my team. it is our } \\
\text { routine to take over the } \\
\text { ADLs and IADLs (such as } \\
\text { making sandwiches) for our } \\
\text { clients. }\end{array}$ & $\begin{array}{c}\text { Never } \\
\mathrm{O}\end{array}$ & 0 & 0 & 0 & $\begin{array}{c}\text { Sometimes } \\
0\end{array}$ & 0 & 0 & 0 & $\begin{array}{c}\text { Always } \\
0\end{array}$ \\
\hline
\end{tabular}




\begin{tabular}{|c|c|c|c|c|c|c|c|c|c|}
\hline 15. & $\begin{array}{l}\text { My organization is not } \\
\text { geared towards involving } \\
\text { clients in the performance } \\
\text { of ADLs and IADLs (such as } \\
\text { independently bathing and } \\
\text { dressing or preparing a } \\
\text { meal). }\end{array}$ & $\begin{array}{l}\text { Completely } \\
\text { disagree } \\
\mathrm{O}\end{array}$ & $\alpha$ & 0 & $\begin{array}{c}\text { Neither agree, } \\
\text { nor disagree } \\
\bigcirc\end{array}$ & $\mathrm{O}$ & 0 & 0 & $\begin{array}{c}\text { Completely } \\
\text { agree } \\
0\end{array}$ \\
\hline 16. & $\begin{array}{l}\text { In my organization, there } \\
\text { are enough people available } \\
\text { who know how to } \\
\text { encourage self-reliance and } \\
\text { independent performance } \\
\text { of activities by clients. }\end{array}$ & $\begin{array}{l}\text { Completely } \\
\text { disagree } \\
\mathrm{Q}\end{array}$ & 0 & 0 & $\begin{array}{c}\text { Neither agree, } \\
\text { nor disagree } \\
0\end{array}$ & 0 & 0 & $Q$ & $\begin{array}{c}\text { Completely } \\
\text { agree } \\
\mathrm{O}\end{array}$ \\
\hline 17. & $\begin{array}{l}\text { My organization offers the } \\
\text { possiblitity to follow internal } \\
\text { or external courses that } \\
\text { focus on encouraging } \\
\text { clients' physical activity }\end{array}$ & $\begin{array}{l}\text { Completely } \\
\text { disagree } \\
0\end{array}$ & $Q$ & 0 & $\begin{array}{c}\text { Neither agree, } \\
\text { nor disagree } \\
0\end{array}$ & O & 0 & $a$ & $\begin{array}{c}\text { Completely } \\
\text { agree } \\
0\end{array}$ \\
\hline 18. & $\begin{array}{l}\text { In my arganization, we do } \\
\text { not have agreements or } \\
\text { guidelines concerning how } \\
\text { we can encourage clients' } \\
\text { physical activity. }\end{array}$ & $\begin{array}{l}\text { Completely } \\
\text { disagree } \\
0\end{array}$ & 0 & 0 & $\begin{array}{c}\text { Neither agree, } \\
\text { nor disagree } \\
0\end{array}$ & 0 & 0 & 0 & $\begin{array}{c}\text { Completely } \\
\text { agree } \\
0\end{array}$ \\
\hline 19. & $\begin{array}{l}\text { I have inadequate time to } \\
\text { activate clents to be self- } \\
\text { reliant because of theneeds } \\
\text { assessment determined by } \\
\text { the community nurse in my } \\
\text { team. }\end{array}$ & $\begin{array}{l}\text { Completely } \\
\text { disagree } \\
0\end{array}$ & 0 & 0 & $\begin{array}{c}\text { Neither agree, } \\
\text { nor disagree } \\
0\end{array}$ & Q & 0 & 0 & $\begin{array}{c}\text { Completely } \\
\text { agree } \\
\text { O }\end{array}$ \\
\hline 20. & $\begin{array}{l}\text { Encouraging self-reliance } \\
\text { and independence has a } \\
\text { high priority in my } \\
\text { organization. }\end{array}$ & $\begin{array}{l}\text { Completely } \\
\text { disagree } \\
0\end{array}$ & 0 & 0 & $\begin{array}{c}\text { Neither agree, } \\
\text { nor disagree } \\
0\end{array}$ & 0 & 0 & 0 & $\begin{array}{c}\text { Completely } \\
\text { agree } \\
0\end{array}$ \\
\hline 21. & $\begin{array}{l}\text { There is a structural } \\
\text { shortage of staff available to } \\
\text { encourage clients to } \\
\text { perform ADLs and IADLs } \\
\text { (such as independently } \\
\text { bathing and dressing or } \\
\text { preparing a meal) as } \\
\text { independently as possible. }\end{array}$ & $\begin{array}{l}\text { Completely } \\
\text { disagree } \\
0\end{array}$ & 0 & 0 & $\begin{array}{c}\text { Neither agree, } \\
\text { nor disagree } \\
\bigcirc\end{array}$ & 0 & 0 & 0 & $\begin{array}{c}\text { Completely } \\
\text { agree } \\
0\end{array}$ \\
\hline
\end{tabular}





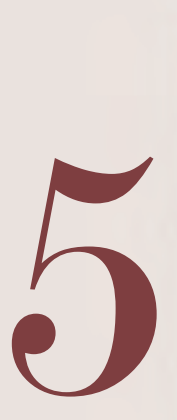

Chapter 5

Process evaluation of a programme to empower community nurse leadership

This chapter was published as: Vogel RGM, Bours GJJW, Rooijackers TH, Metzelthin SF, Erkens PMG, van Rossum E, Zwakhalen SMG. Process evaluation of a programme to empower community nurse leadership. BMC Nursing 20, 127 (2021). https://doi.org/10.1186/s12912-021-00650-y 


\section{Abstract}

\section{Background}

The Nurses in the Lead (NitL) programme consists of a systematic approach and training to 1) empower community nurses in implementing evidence, targeted at encouraging functional activities of older adults, and 2) train community nurses in enabling team members to change their practice. This article aims to describe the process evaluation of NitL.

\section{Methods}

A mixed-methods formative process evaluation with a predominantly qualitative approach was conducted. Qualitative data were collected by interviews with community nurses $(n=7)$, focus groups with team members $(n=31)$, and reviewing seven implementation plans and 28 patient records. Quantitative data were collected among community nurses and team members $(n=90)$ using a questionnaire to assess barriers in encouraging functional activities and attendance lists. Data analysis was carried out through descriptive statistics and content analysis.

\section{Results}

NitL was largely executed according to plan. Points of attention were the use and value of the background theory within the training, completion of implementation plans, and reporting in patient records by community nurses. Inhibiting factors for showing leadership and encouraging functional activities were a lack of time and a high complexity of care; facilitating factors were structure and clear communication within teams. Nurses considered the systematic approach useful and the training educational for their role. Most team members considered NitL practical and were satisfied with the coaching provided by community nurses. To optimise NitL, community nurses recommended providing the training first and extending the training. The team members recommended continuing clinical lessons, which were an implementation strategy from the community nurses.

\section{Conclusions}

NitL was largely executed as planned, and appears worthy of further application in community care practice. However, adaptations are recommended to make NitL more promising in practice in empowering community nurse leadership in implementing evidence. 


\section{Background}

Community-based care provision is becoming more complex due to an ageing society and the rising number of older adults with chronic diseases ${ }^{1}$. In this increasingly challenging context, community nurses are seen as key players within the Dutch community care setting ${ }^{2}$. These nurses are bachelor-educated and in charge of a community care team consisting of 10-15 registered nurses, certified nurse assistants and helping aids. Community nurses are at the forefront of improving quality of care and leading their team members throughout this process in practice ${ }^{3}$. In this study, we define nurse leadership as "a process where nurses can develop observable leadership competencies and attributes needed to improve patient outcomes, personnel outcomes and organisational outcomes" ${ }^{\prime 4}$. Their leadership role enables them to implement evidence into community care and contribute to enhancing patient outcomes ${ }^{3}$.

The Nurses in the Lead (NitL) programme was designed to empower community nurse leadership in implementing evidence, targeted at encouraging functional activities of older adults ${ }^{5}$. Empowerment in this context means that community nurses are strengthened in their leadership role - to implement specific evidence within community care, and lead their team members throughout this process. By empowering their leadership, more evidence for encouraging functional activities of older adults may be implemented in practice. Performing functional activities independently, for example (instrumental) activities of daily living ([I]ADL), can maintain functional independence and autonomy of older adults ${ }^{6,7}$. However, nurses are traditionally familiar with completing care activities for older adults ${ }^{8-10}$ and, therefore, it is key to implement evidence for encouraging functional activities of older adults.

The NitL programme entails two components ${ }^{5}$. First, a systematic approach based on the Implementation of Change Model ${ }^{11}$ to empower nurses in implementing evidence. This approach contains six implementation steps and five implementation tools, which can guide them in systematically implementing evidence, provided via an e-learning programme. The second component is group training to empower nurses in enabling team members to change their practice, focusing on motivational interviewing ${ }^{12}$, dealing with resistance to change, and the coaching of teams ${ }^{13-15}$.

We evaluated NitL's outcomes and conducted a process evaluation. The evaluation of the outcomes is reported elsewhere ${ }^{16}$, showing that the programme was perceived as valuable and may lead to positive impacts for strengthening leadership. The current study reports on process evaluation, according to the framework of Saunders et al. ${ }^{17}$, and aims to evaluate the process of implementing NitL in practice. The following overall research question and sub-questions guided the study: How was the NitL programme implemented into community care practice?

The following sub-questions were formulated to help answer this overall question:

A. To what extent are the components of NitL delivered and received?

B. To what extent is attendance achieved? 
C. To what extent is the programme implemented as planned?

D. To what extent is satisfaction with the programme experienced?

E. To what extent were barriers and facilitators encountered while implementing NitL?

\section{Methods}

\section{Context}

NitL was delivered in seven community care teams from two long-term care organisations, providing community care to patients. The organisations consist of several community care teams that each comprise 10-15 team members and one community nurse. The bachelor-educated community nurse is in charge of the team members, who can either be registered nurses with a bachelor's degree or vocational training, or certified nurse assistants or helping aids with a secondary training. These teams provide personal care such as washing, and nursing care such as wound treatment. The community nurse determines what and how much care is needed for clients, while taking prevention, tailored care and advice into account ${ }^{18}$.

\section{Design}

A mixed-methods formative process evaluation, with a predominantly qualitative approach, was conducted during February 2018-January 2019, following the conventional ${ }^{19,20}$ process indicators of Saunders et al. ${ }^{17}$. NitL was implemented in three consecutive rounds of 8 months. A formative evaluation was conducted to anticipate implementation difficulties during subsequent rounds, and possibly adjust the NitL programme. Formative evaluations are often designed using mixed methods, to be able to gain a deeper understanding of how a programme is implemented ${ }^{21-23}$. By combining qualitative and quantitative methods, we were able to provide broader insights on the implementation of NitL. We could ensure that quantitative results were combined with the experiences of community nurses and team members, and improve our understanding of the components of NitL in practice ${ }^{24}$. Qualitative data were collected via interviews with community nurses, focus group interviews with their team members, and reviews of implementation plans and patient records. Quantitative data were collected by a questionnaire to assess barriers in encouraging functional activities among community nurses and team members ${ }^{25}$ and a review of attendance lists. The study is reported following the Good Reporting of a Mixed Methods Study $\left(\right.$ GRAMMS) ${ }^{26}$. 


\section{Setting and sample}

Seven bachelor-educated community nurses from two community care organisations were recruited via convenience sampling to participate. Purposeful sampling was used to recruit a minimum of 14 team members (at least two per community care team) to participate in the focus group interviews based on variations in demographic characteristics (profession, education, work experience, specific focus area within the team, and work hours per week). The seven community nurses and all 83 team members were invited to participate in the quantitative data collection. In addition, 28 patient records of older adults were purposefully sampled, based on selection criteria of being aged over 75 years and receiving community nursing care by one of the community care teams.

\section{The NitL programme}

The development and content of NitL is described in more detail elsewhere ${ }^{5}$. The programme was based on the learning needs of seven community nurses, who also participate in the current study. The first component of NitL, the systematic approach, consists of six implementation steps that nurses can use to develop an implementation plan. For example, in the first step, nurses are guided in developing a proposal for change. To complete the steps, they can use several practical implementation tools, such as a format for developing the implementation plan and the Maastricht Nurses Activities Inventory for Community care (MAINtAIN-C) questionnaire, to measure the perceived behaviour and barriers of their team members in encouraging functional activities $^{25}$. The second component is training to empower community nurses in enabling team members to change practice. The training is a blend of 4-hour face-toface group training and background theory offered via e-learning. It addresses motivational interviewing ${ }^{12}$, dealing with resistance to change and coaching care teams, for example during peer supervision meetings ${ }^{13-15}$. During the first 2 months of the implementation, nurses developed an implementation plan by making use of the elearning (i.e., the systematic approach). Implementation tools could be used to complete the plan. Two or three community nurses together developed an implementation plan, and received support via bimonthly meetings with an interventionist (author RGMV) experienced in implementation processes and with a nursing background. During the following 6 months, the nurses implemented their plan in practice and had monthly meetings with the interventionist to evaluate the process. They also received group training at this time (Web-based e-learning was constantly available.)

\section{Measurement instruments and data collection}

We assessed the process indicators dose delivered, dose received exposure, reach, fidelity, dose received satisfaction and context, according to the framework of Saunders 
et al. ${ }^{17}$. Table 5.1 provides insight into the operationalisation of the components and data collection methods.

Table 5.1 Outcome measures, operationalisation and data collection of the process evaluation.

\begin{tabular}{|c|c|c|}
\hline Measures & Operationalisation & Data collection methods \\
\hline $\begin{array}{l}\text { Dose } \\
\text { delivered }\end{array}$ & $\begin{array}{l}\text { The extent to which the components of the NitL } \\
\text { programme, namely the systematic approach and } \\
\text { training, were delivered to community nurses } \\
\text { and all intended content of the programme } \\
\text { covered. }\end{array}$ & Interviews with community nurses \\
\hline $\begin{array}{l}\text { Dose received } \\
\text { exposure }\end{array}$ & $\begin{array}{l}\text { The extent to which community nurses actively } \\
\text { engaged with and used the systematic NitL } \\
\text { approach and training. }\end{array}$ & Interviews with community nurses \\
\hline Reach & $\begin{array}{l}\text { The proportion of community nurses who } \\
\text { attended plenary meetings during the } \\
\text { implementation of NitL. }\end{array}$ & Attendance lists \\
\hline Fidelity & $\begin{array}{l}\text { The extent to which NitL was implemented as } \\
\text { planned, related to } 1 \text { ) how community nurses } \\
\text { implemented evidence for encouraging } \\
\text { functional activities and enabled team members } \\
\text { to change practice, and } 2 \text { ) how team members } \\
\text { were enabled by community nurses to encourage } \\
\text { functional activities. }\end{array}$ & $\begin{array}{l}\text { Interviews with community nurses } \\
\text { Focus groups with team members } \\
\text { Patient records } \\
\text { Implementation plans }\end{array}$ \\
\hline $\begin{array}{l}\text { Dose received } \\
\text { satisfaction }\end{array}$ & $\begin{array}{l}\text { The satisfaction of } 1 \text { ) community nurses with the } \\
\text { programme related to implementing evidence for } \\
\text { encouraging functional activities, and enabling } \\
\text { team members to change practice, and } 2 \text { ) team } \\
\text { members, related to encouraging functional } \\
\text { activities and how they were enabled to change } \\
\text { practice by community nurses. }\end{array}$ & $\begin{array}{l}\text { Interviews with community nurses } \\
\text { Focus groups with team members }\end{array}$ \\
\hline Context & $\begin{array}{l}\text { The extent to which barriers and/or facilitators } \\
\text { were encountered while implementing the NitL } \\
\text { programme related to } 1 \text { ) community nurses while } \\
\text { implementing evidence and enabling team } \\
\text { members to change practice, and } 2 \text { ) team } \\
\text { members while encouraging functional activities } \\
\text { and being enabled to change practice by } \\
\text { community nurses. }\end{array}$ & $\begin{array}{l}\text { Interviews with community nurses } \\
\text { Focus groups with team members } \\
\text { MAINtAIN-C questionnaire }\end{array}$ \\
\hline
\end{tabular}

\section{Qualitative data collection}

Interviews with community nurses were conducted by one researcher (author RGMV) during the sixth month of implementation and 1 month after the implementation. Focus group interviews with team members were conducted 1 month after implementation by two researchers (authors RGMV and GJJWB). The topic lists for the interviews were based on the components of Saunders et al. ${ }^{17}$ (for more details see Additional File 5.1). Data saturation level was reached (enough in-depth data was available ${ }^{27}$ ) after 6 interviews with nurses ( 2 with nurses in the first round, 2 in the second round, and 2 in the third) and three focus groups with team members. To review implementation plans, a checklist was developed (see Additional File 5.2) based 
on the Implementation of Change Model $^{11}$ to assess whether the plans matched given implementation steps within the systematic approach. The plans were reviewed in January 2019 by two researchers (authors GJJWB and PMGE).

To review the patient records, a checklist was developed (see Additional file 5.3) to assess whether nursing diagnoses, interventions and outcomes related to encouraging functional activities ( $A D L, I A D L$ ) were described by community nurses and reported by their team members. Patient records were retrospectively reviewed in January 2019 by one researcher (author RGMV) looking at the fifth, sixth, seventh and eighth month of each implementation round.

\section{Quantitative data collection}

The MAINtAIN-C Barriers scale ${ }^{25}$ was completed by community nurses and their team members. The scale measures their perceived barriers in encouraging functional activities, with seven items related to clients' context ( $\alpha=.78)$ and 21 items related to the context of professionals, the social and organisational context $(\alpha=.83)$. In an earlier study, the scale was adapted from the MAINtAIN scale for nursing homes by the same seven community nurses as participated in this study ${ }^{25}$. The scale was sent to the community nurses and the nurses in their teams 1 month after the implementation via an online programme. Between 2 and 4 weeks after the initial invitation, reminder emails were sent to the non-responders. Further, background characteristics (e.g. age and years of work experience) of community nurses and team members were assessed via the scale. Attendance lists were used in support meetings with the interventionist, and in group training.

\section{Data analysis}

\section{Qualitative data analysis}

Interviews and focus groups were audiotaped and transcribed verbatim. NVivo 11 was used as supportive software ${ }^{28}$. Based on the principles of directed content analyses ${ }^{29}$, the topic lists were used as a guiding analytical framework to analyse the data. At first, data were coded following the topics, by author RGMV. A second author (GJBB) verified the developed codes by looking at text, codes and topics. This was discussed during consensus meetings with authors RGMV and GJJB. Differences in interpretation were solved by dialogue to reach consensus. Subsequently, two authors (RGMV and THR) independently grouped the earlier developed codes until sub-categories emerged. Any differences in interpretation were discussed until consensus was reached. Finally, one researcher (author GJJB) verified the categories and made minor adaptations. A professional native-speaker translated the quotes into English. For the review of implementation plans, two researchers (authors GJJB and PMGE) independently assessed if each step was described completely, partly, or not at all. This was discussed with one researcher (author RGMV) and any discrepancies in scoring were resolved 
until consensus was reached. For the review of patient records, one author (RGMV) analysed if and which nursing diagnoses, interventions and outcomes were described and reported in the records. The analysis of the first four records was discussed with another researcher (GJJWB) to reach consensus.

\section{Quantitative data analysis}

Quantitative data were analysed using IBM SPSS Statistics 25.0 for Windows ${ }^{30}$. Descriptive statistics were used to present the characteristics of the study sample. For the MAINtAIN-C Barriers scale, missing values were imputed based on the average score of all respondents on all items for the team members, or with the average score of all respondents on the missing item for the community nurses, if at least $80 \%$ of items had been completed. Those missing more than $20 \%$ were excluded from the analyses. The positively formulated items were reversed, to make sure that higher scores indicate stronger experienced barriers. Further, descriptive statistics were used to develop an overview of attendance.

\section{Synthesis of mixed methods}

After separate analysis of quantitative and qualitative data, findings were merged following the convergent mixed-methods design ${ }^{24}$. A side-by-side analysis was undertaken by discussing first the qualitative findings and then quantitative results. In this way, both qualitative data (views of community nurses and their team members) and quantitative data (from the questionnaire) provided a complete understanding ${ }^{24}$.

\section{Trustworthiness}

Several strategies were used to meet the criteria of credibility, transferability and confirmability $^{31}$ to enhance the trustworthiness of the study ${ }^{32}$. First, credibility was enhanced by triangulation of investigators and data. Triangulation of investigators involved a reflection of all the authors on the design, collection and analyses of the study. Furthermore, the coding, analysing and interpreting of data were completed by two researchers. Triangulation of data was achieved by including different sources within the study (multiple respondents in focus groups and multiple interviews). To enhance confirmability, two researchers performed the qualitative data analysis.

\section{Results}

\section{Sample characteristics}

Table 5.2 provides baseline characteristics of the seven community nurses, 31 team members who participated in three focus groups (with, respectively, 10, 11 and 10 participants) and 69 team members who completed the MAINtAIN-C questionnaire. 
Missing data on the MAINtAIN-C questionnaire were due to sickness, absence or leaving the team. For the review of patient records, 28 older adults with a median age of 82 years $(S D=5.5)$ gave consent to participate; 16 were female.

Table 5.2 Sample characteristics of community nurses $(n=7)$ and team members that participated in the focus groups $(n=31)$ and completed the questionnaire $(n=69) .^{*}$

\begin{tabular}{|c|c|c|c|c|c|c|c|}
\hline & & \multicolumn{2}{|c|}{$\begin{array}{l}\text { Community nurses } \\
\qquad(n=7)\end{array}$} & \multicolumn{2}{|c|}{$\begin{array}{c}\text { Team members } \\
(n=31)\end{array}$} & \multicolumn{2}{|c|}{$\begin{array}{c}\text { Team members } \\
(n=69)\end{array}$} \\
\hline & & $n$ & $\%$ & $n$ & $\%$ & $n$ & $\%$ \\
\hline Gender & Female & 6 & 85.7 & 30 & 96.8 & $67 * *$ & 97.1 \\
\hline \multirow[t]{3}{*}{ Profession } & $\begin{array}{l}\text { Bachelor-educated } \\
\text { nurse }\end{array}$ & 7 & 100.0 & 4 & 12.9 & $9 * *$ & 13.0 \\
\hline & $\begin{array}{l}\text { Vocationally } \\
\text { educated nurse }\end{array}$ & & & 9 & 29.0 & 13 & 18.8 \\
\hline & $\begin{array}{l}\text { Certified nurse } \\
\text { Assistant/Helping } \\
\text { aid/Nursing student }\end{array}$ & & & 18 & 58.1 & 45 & 65.2 \\
\hline \multirow[t]{5}{*}{ Education } & Master of science & 2 & 28.6 & & & $9 * * *$ & 13.0 \\
\hline & Bachelor of nursing & 5 & 71.4 & 5 & 16.1 & 18 & 26.1 \\
\hline & Vocational training & & & 11 & 35.5 & 38 & 55.1 \\
\hline & Secondary training & & & 15 & 48.4 & & \\
\hline & & Median & $\begin{array}{c}\text { Range } \\
{[\min -\max ]}\end{array}$ & Median & $\begin{array}{c}\text { Range } \\
{[\min -\max ]}\end{array}$ & Median & $\begin{array}{c}\text { Range } \\
{[\min -\max ]}\end{array}$ \\
\hline Age in years & & 34 & $31[26-56]$ & 51 & $12.1[22-61]$ & $49 * *$ & $43[21-64]$ \\
\hline $\begin{array}{l}\text { Work experience } \\
\text { in years }\end{array}$ & & 14 & 31 [7-38] & 22 & $11.0[5-41]$ & $19 * * *$ & $47[1-47]$ \\
\hline $\begin{array}{l}\text { Working hours } \\
\text { per week }\end{array}$ & & 32 & $12[24-36]$ & 24 & $6.6[8-36]$ & $24^{* *}$ & $33[7-40]$ \\
\hline
\end{tabular}

*For data of community nurses $(n=7)$ on the MAINtAIN-C Barriers, missing data of two respondents with one missing item was imputed. For data of team members $(n=69)$ on the MAINtAIN-C Barriers, missing data of three respondents were imputed (of whom one respondent had one missing item, one respondent had two missing items and one respondent had three missing items). ${ }^{* *}$ Based on $\mathrm{n}=67$ due to missing data. $* * *$ Based on $\mathrm{n}=65$ due to missing data.

\section{Results per process component}

We describe the results per component according to the framework of Saunders et al. 17 .

\section{Dose delivered, dose received exposure and reach}

\section{Community nurses}

NitL was delivered as intended (dose delivered) since the systematic approach and training were undertaken. NitL was partly received as intended since all nurses developed implementation plans and engaged in group training, but only four actively used the background theory within the training (dose received exposure). The community nurses attended all planned plenary meetings (reach). 


\section{Fidelity}

\section{Community nurses}

In Additional File 5.4, Box 1, nurses' planned implementation strategies are presented. According to the nurses, the strategies were implemented largely in practice, such as in coaching team members.

Yes, I have had individual discussions. I have questioned team members, for example, you are responsible for this client, was your starting point client selfreliance and encouraging functional activities? I have asked people how this went, and were there things that were difficult. How can I help you with this? (Community nurse 6)

Two strategies were not fully implemented as intended, namely providing information flyers to new clients and shadowing team members in practice. The review of implementation plans showed that all nurses developed a plan, however not all nurses described the evaluation of the plan and developed Specific, Measurable, Acceptable, Realistic and Time-bound (SMART) goals ${ }^{11}$.

The review of patient records showed the degree to which diagnoses, interventions and outcomes related to encouraging ADL and IADL. Only a few nursing diagnoses, related to $A D L$, were described by community nurses and reported in patient records by team members. Nursing interventions and outcomes were described in over half of the included records by nurses, mainly for ADL, and reported in two out of three cases by team members. The results are reported in Table 5.3.

Table 5.3 Nursing diagnoses, interventions and outcomes regarding encouraging functional activities as described and reported in patient records $(n=28)$.

\begin{tabular}{lcc}
\hline Diagnoses & $\begin{array}{c}\text { Number of records (\%) } \\
\text { described }\end{array}$ & $\begin{array}{c}\text { Number of records (\%) } \\
\text { reported }\end{array}$ \\
ADL & $4(14.3)$ & $3(10.7)$ \\
IADL & $0(0.0)$ & $0(0.0)$ \\
General activities & $0(0.0)$ & $0(0.0)$ \\
Interventions & & \\
ADL & $16(57.1)$ & $11(39.3)$ \\
IADL & $0(0.0)$ & $0(0.0)$ \\
General activities & $2(7.1)$ & $1(3.6)$ \\
Outcomes & & \\
ADL & $15(53.6)$ & $10(35.7)$ \\
IADL & $0(0.0)$ & $0(0.0)$ \\
General activities & $0(0.0)$ & $0(0.0)$ \\
\hline
\end{tabular}

\section{Team members}

Most team members acknowledged they were motivated by community nurses to encourage functional activities. Several members stated that they had been appointed 
as local opinion leaders by community nurses to lead the encouragement of functional activities in practice:

In addition, the community nurse also appointed a group for the project, they conducted and steered the programme and they had regular meetings. Then, mail or messages were used to keep us informed. (Team member 2)

Most of the members stated that encouraging functional activities became a fixed agenda item during team meetings. They also indicated that two nurses and a local opinion leader shadowed them during their daily work in practice:

Yes, and the community nurse worked alongside everyone to see how we did it. This wasn't for control, rather more to observe how we did it and afterwards to give tips. It was fine. (Team member 2)

\section{Dose received satisfaction}

\section{Community nurses}

All nurses were generally positive about the programme. They indicated that NitL made them more conscious about their routines, enabled team members to change practice and encouraged functional activities in older adults. They found the systematic approach and the training useful to further develop their role, and indicated that it was feasible to develop an implementation plan for themselves in future.

Yes, what you must do was very clearly written, the steps were extensively described, so I found it a clear system in the way that it was written out. (Community nurse 7)

However, opinions concerning the background theory varied. Three nurses indicated they did not consider the theory relevant for strengthening their leadership, whereas four nurses appreciated the information.

Yes, I think that it was valuable, a little refresh [of] your memory about that part of the theory. (Community nurse 7)

Well, it didn't make that much of an impression on me. (Community nurse 4)

Some nurses suggested adapting the delivery of NitL by first providing the training, followed by the systematic approach, as well as providing more group training. Other recommendations were extending the implementation period, and implementing NitL within more community care teams in the organisation.

Yes, but we could have given more input in the regions, it remained within our team. It was a missed opportunity to broaden the implementation. (Community nurse 4)

They also recommended providing fewer examples of implementation strategies within the approach to leave more room for their own interpretation, simplifying the elearning design, focusing more on motivational interviewing in the training, and shortening the MAINtAIN-C questionnaire. Nurses would also have liked the opportunity to collaborate with participating nurses from the other organisation. 


\section{Team members}

The team members were positive about NitL, indicating that the content was in line with current practice and with the vision of their organisation. Most team members were satisfied with the coaching from community nurses and found clinical lessons educational.

Then the community nurse said, occasionally, 'Hey, you can try this, think about this or that', and then I could consider it. Looking at things in that way is fine. (Team member 6)

Some team members recommended extending clinical lessons after the implementation, and some members recommended better and more communication between the hospital setting and their organisations on encouraging functional activities of older adults.

\section{Context}

\section{Community nurses}

Community nurses valued collaboration with other nurses and interventionists, as well as the facilitation of the organisation to be part of this research. A structured plan and the official status of NitL helped their team members encourage functional activities.

I also see with my team that it really helps when they can follow an action plan, and not that once again something vague is dropped on them. (Community nurse 1)

Nurses indicated that time constraints combined with a high complexity of care were barriers to implementing evidence. Another inhibiting factor was that not all team members were aware of the importance of encouraging activities in older adults. Some nurses also stated that the individual provision of community care (instead of in a team) was a barrier for enabling their team members to change practice.

I find it difficult to check, you know, if the team members actually do that in practice because you don't see that when you work in home care, you don't see what someone says, tells, or asks a client. That makes it difficult. (Community nurse 3)

The three strongest perceived barriers from the MAINtAIN-C Barriers scale were item 1, "clients are often able to perform ADLs more independently than they now do" $(M=6.29, S D=2.43)$ and item 4, "family or informal caregivers expect the nurses and nurse assistants to take over the activities that clients themselves can still perform" $(M=5.71, S D=2.06)$. Further, they experienced item 3, "clients ask for help with ADLs so that they can get extra attention" $(M=5.29, S D=0.76)$ as a barrier.

\section{Team members}

According to team members, clear communication and structure, and agreements within the team were facilitators for encouraging functional activities of older adults. 
Barriers were a lack of time combined with high complexity of care and too few team meetings to discuss matters on encouraging activities as a group. They also acknowledged that expectations about receiving or providing care could be a hindrance in encouraging functional activities.

The two strongest barriers perceived by team members were the same as for community nurses, namely item $1(M=6.75, S D=2.00)$ and item $4(M=5.64, S D=1.56)$. They also experienced item 2 "clients are afraid to walk on their own, without help from others" $(M=5.39, S D=1.40)$ as a barrier.

\section{Discussion}

The results of this study show that the NitL programme was largely executed according to plan. NitL components were delivered and received, and all community nurses developed implementation plans, engaged in group training and attended plenary meetings. Most implementation strategies were realised; however, not all implementation plans were complete. Community nurses perceived NitL as useful and educational, and most team members were satisfied with coaching from the community nurses. For both nurses and team members, time constraints combined with a high complexity of care were barriers in practice, and that clients are often able to perform ADLs more independently than they now do. In contrast, clear communication and a structured plan were facilitators. For optimisation of the programme, community nurses recommended providing the training first, followed by the systematic approach, as well as providing more group training. The team members recommended continuing the provision of clinical lessons (an implementation strategy of the community nurses).

In our study, there was limited use by nurses of the background theory via the elearning programme. This may be explained by the fact that not all community nurses in our study considered the background theory relevant. Previous research also indicates that e-learning is not effective on its own, but rather depends on the extent to which the content and its use are perceived as necessary ${ }^{33}$. Another explanation may be that instructions on using the background theory were not clear enough ${ }^{33,34}$. For future implementations of NitL, it is necessary to give greater consideration to the goal, content and instructions of the background theory via the e-learning programme ${ }^{33,34}$.

Only a few community nurses in our study fully completed the implementation plans by developing SMART implementation goals and describing the evaluation of the plans. Although an interventionist experienced in implementation processes was available to support nurses during the development of the implementation plans, no prior training was given to increase skills and knowledge in developing such plans. As indicated during the interviews, it might be the case that a lack of time was a factor, or a lack of knowledge or skills, when designing and completing implementation plans. The studies by Mallion et al. ${ }^{35}$ and Gifford et al. ${ }^{36}$ support the view that the barriers perceived by 
community nurses during an implementation process are a lack of time, knowledge and skills. Hence, for future implementations of NitL, more training to increase skills and knowledge for developing an implementation plan is necessary. Moreover, as recommended by community nurses during interviews, group training should be provided first, followed by the systematic approach. Further, the description and reporting of nursing diagnoses, interventions and outcomes related to encouraging functional activities were mainly limited to ADL. An explanation could be that the community nurses and their team members primarily encourage $A D L$, as the provision of IADL care is more the responsibility of domestic workers ${ }^{37}$.

\section{Strengths and limitations}

Although nurse leadership improves high-quality community care, sound evaluation studies on programmes to empower nurse leadership remain scarce ${ }^{38}$. This process evaluation combined qualitative and quantitative methods and incorporated data from both community nurses and their team members from two long-term care organisations, which provided more profound insights into the implementation of the programme and increased trustworthiness of results. A limitation of the study may be that motivated community nurses have been overrepresented since convenience sampling was applied, which potentially may have led to a more positive evaluation of NitL. Further research is needed to determine whether our findings can be generalised to other community care teams. Another limitation was that the researcher who conducted the interviews was also involved as an interventionist, which may have led to socially desirable answers by community nurses and team members. However, respondents were informed about the anonymous treatment of data.

\section{Implications}

The programme was perceived as worthwhile by community nurses and their team members. However, attention should be paid to adapting several aspects of the programme. First, more consideration should be given to the goal, content and blended perspective of the background theory via the e-learning programme. Second, we recommend adapting the delivery and content of the components of NitL. Group training should be extended and the training should be provided first, followed by the systematic approach. NitL can then be used to develop community nurse leadership in implementing evidence further to support the delivery of high-quality community care. Further research is needed to provide insights into the effects of NitL on community nurse leadership. 


\section{Conclusion}

In this study, the implementation of NitL into community care practice was evaluated. The programme consists of a systematic approach and training to 1) empower community nurses in implementing evidence, targeted at encouraging functional activities of older adults, and 2) train community nurses in enabling team members to change their practice. Our results indicated that NitL was largely executed as planned in practice. The systematic approach and training appear to strengthen the leadership of community nurses in systematically implementing evidence, and enabling team members to change practice. Adaptations to the programme are recommended, such as providing more training to community nurses. The programme can then be used to empower community nurse leadership in the community care setting, and support the provision of high-quality care. 


\section{References}

1. European Commission. The 2018 ageing report - underlying assumptions \& projection methodologies. 2017. Available from: https://ec.europa.eu/info/sites/info/files/economy-finance/ip065_en.pdf.

2. Steering Committee National Quality Framework for Community Care (Stuurgroep Kwaliteitskader Wijkverpleging). National Quality Framework for Community Care (Kwaliteitskader Wijkverpleging). 2018.

3. Rosendal H. Expertisegebied Wijkverpleegkundige [Community Nurses' Area of Expertise]: V\&VN; 2019.

4. Heinen $M$, van Oostveen C, Peters J, Vermeulen H, Huis A. An integrative review of leadership competencies and attributes in advanced nursing practice. Journal of advanced nursing. 2019;75(11):2378-92.

5. Vogel R, Bours G, Erkens P, Metzelthin S, Zwakhalen S, van Rossum E. The content of the nurses in the lead programme for empowering community nurse leadership in implementing evidence. Leadership in Health Services. 2021.

6. Winkel A, Langberg H, Wæhrens EE. Reablement in a community setting. Disability and Rehabilitation. 2015;37(15):1347-52.

7. Connolly D, Garvey J, McKee G. Factors associated with ADL/IADL disability in community dwelling older adults in the Irish longitudinal study on ageing (TILDA). Disability and Rehabilitation. 2017;39(8):809-16.

8. Oliver D, Foot C, Humphries R. Making our Health and Care Systems Fit for an Ageing Population: King's Fund London: UK; 2014.

9. Beresford B, Mann R, Parker G, Kanaan M, Faria R, Rabiee P, et al. Work package 2b: delivering reablement-practitioner views. Reablement services for people at risk of needing social care: the MoRe mixed-methods evaluation: NIHR Journals Library; 2019.

10. Whitehead PJ, Worthington EJ, Parry RH, Walker MF, Drummond AE. Interventions to reduce dependency in personal activities of daily living in community dwelling adults who use homecare services: a systematic review. Clinical rehabilitation. 2015;29(11):1064-76.

11. Grol R, Wensing M, Eccles M, Davis D. Improving patient care: The Implementation of Change in Health Care. Hoboken, New Jersey: John Wiley \& Sons; 2013.

12. Miller WR, Rollnick S. Motivational Interviewing: Helping People Change: Guilford Press; 2012.

13. Goossens W. Integrale procesbegeleiding van groepen. J Remmerswaal ea (red), Handboek Werken, leren en leven met groepen C. 2004;2600.

14. Leary T. Interpersonal Diagnosis of Personality: A Functional Theory and Methodology for Personality Evaluation: Wipf and Stock Publishers; 2004.

15. Balint M. The doctor, his patient, and the illness. The Lancet. 1955;265(6866):683-8.

16. Vogel RGM, Bours GJJW, Erkens PMG, Metzelthin SF, Breukelen GJP, van Rossum E, et al. Outcomes of the 'Nurses in the Lead' programme to empower community nurse leadership: a pre-post-test study. Manuscript submitted for publication.

17. Saunders RP, Evans MH, Joshi P. Developing a process-evaluation plan for assessing health promotion program implementation: a how-to guide. Health promotion practice. 2005;6(2):134-47.

18. Cramm JM, Nieboer AP. Self-management abilities and quality of life among frail community-dwelling individuals: The role of community nurses in the Netherlands. Health and Social Care in the Community. 2017;25(2):394-401.

19. Metzelthin SF, Daniëls R, van Rossum E, Cox K, Habets H, de Witte LP, et al. A nurse-led interdisciplinary primary care approach to prevent disability among community-dwelling frail older people: a large-scale process evaluation. International journal of nursing studies. 2013;50(9):1184-96.

20. Stijnen MM, Jansen MW, Duimel-Peeters IG, Vrijhoef HJ. Nurse-led home visitation programme to improve health-related quality of life and reduce disability among potentially frail community-dwelling older people in general practice: a theory-based process evaluation. BMC family practice. 2014;15(1): $1-14$.

21. Zarrett N, Abraczinskas M, Cook BS, Wilson D, Roberts A. Formative Process Evaluation of the "Connect" Physical Activity Feasibility Trial for Adolescents. Clinical Medicine Insights: Pediatrics. 2020;14:1179556520918902.

22. Moore GF, Audrey S, Barker M, Bond L, Bonell C, Hardeman W, et al. Process evaluation of complex interventions: Medical Research Council guidance. bmj. 2015;350:h1258. 
23. Odendaal W, Atkins S, Lewin S. Multiple and mixed methods in formative evaluation: Is more better? Reflections from a South African study. BMC medical research methodology. 2016;16(1):1-12.

24. Creswell JW. A concise introduction to mixed methods research: SAGE publications; 2014.

25. Vogel RGM, Bours GJJW, Metzelthin SF, Erkens PMG, van Breukelen GJP, Zwakhalen SMG, et al. The perceived behavior and barriers of community care professionals in encouraging functional activities of older adults: the development and validation of the MAINtAIN-C questionnaire. BMC Health Services Research. 2020;20(1):907.

26. O'cathain A, Murphy E, Nicholl J. The quality of mixed methods studies in health services research. Journal of Health Services Research \& Policy. 2008;13(2):92-8.

27. Moser A, Korstjens I. Series: Practical guidance to qualitative research. Part 3: Sampling, data collection and analysis. European Journal of General Practice. 2018;24(1):9-18.

28. Mortelmans D. Kwalitatieve analyse met Nvivo. Tweede, herwerkte druk. ed. Leuven ;: Acco; 2017.

29. Hsieh H-F, Shannon SE. Three approaches to qualitative content analysis. Qualitative health research. 2005;15(9):1277-88.

30. IBM. IBM SPSS Statistics for Windows, Version Q3 25.0. Armonk, NY: IBM Corp. 2017.

31. Korstjens I, Moser A. Series: Practical guidance to qualitative research. Part 4: trustworthiness and publishing. European Journal of General Practice. 2018;24(1):120-4.

32. Lincoln YS, Guba EG. Naturalistic inquiry. Beverley Hills. CA: Sage; 1985.

33. Dankbaar M. De effectiviteit van e-learning en de implementatie in het medisch onderwijs. Tijdschrift voor medisch onderwijs. 2009;28(5):212-22.

34. Liu Q, Peng W, Zhang F, Hu R, Li Y, Yan W. The effectiveness of blended learning in health professions: systematic review and meta-analysis. Journal of Medical Internet Research. 2016;18(1):e2.

35. Mallion J, Brooke J. Community-and hospital-based nurses' implementation of evidence-based practice: are there any differences? British journal of community nursing. 2016;21(3):148-54.

36. Gifford. WA, Davies BL, Graham ID, Tourangeau A, Woodend AK, Lefebre N. Developing leadership capacity for guideline use: A pilot cluster randomized control trial. Worldviews on Evidence-Based Nursing. 2013;10.

37. Genet N, Boerma W, Kroneman M, Hutchinson A, Saltman R. Home care across Europe: case studies. 2013.

38. Erkens PMG, Vogel RGM, van Rossum E, Metzelthin SF, Meijers JMM, Zwakhalen SMG, et al. Nurse leadership in long-term care: a systematic review on leadership programs. Manuscript submitted for publication. 


\section{Supplementary information}

\section{Additional File 5.1. Topic list with examples of the questions of the interviews}

\begin{tabular}{|c|c|}
\hline Topics & $\begin{array}{l}\text { Examples of questions from the interviews with community } \\
\text { nurses }\end{array}$ \\
\hline Fidelity & $\begin{array}{l}\text { Have you executed the strategies from the implementation plan } \\
\text { to implement evidence for encouraging functional activities? } \\
\text { If yes, can you amplify your answer? }\end{array}$ \\
\hline Dose delivered & $\begin{array}{l}\text { Were you able to open the systematic approach via the e-learning } \\
\text { programme? } \\
\text { If yes, can you name some of the depicted content? }\end{array}$ \\
\hline Dose received exposure & $\begin{array}{l}\text { Did you use the background theory of the systematic approach via } \\
\text { the e-learning programme? } \\
\text { If yes, can you amplify your answer? }\end{array}$ \\
\hline Dose received satisfaction & $\begin{array}{l}\text { How satisfied were you with the NitL programme? } \\
\text { Can you amplify your answer? }\end{array}$ \\
\hline Context & $\begin{array}{l}\text { Did you experience any facilitators in developing the } \\
\text { implementation plan? } \\
\text { If yes, what were these facilitators? }\end{array}$ \\
\hline Topics & $\begin{array}{l}\text { Examples of questions from the focus groups with team } \\
\text { members }\end{array}$ \\
\hline Fidelity & $\begin{array}{l}\text { Did the community nurse of your team enable you to change your } \\
\text { practice in encouraging functional activities of older adults? } \\
\text { If yes, can you amplify your answer? }\end{array}$ \\
\hline Dose received satisfaction & $\begin{array}{l}\text { How satisfied were you with the coaching you received from the } \\
\text { community nurse of your team? }\end{array}$ \\
\hline Context & $\begin{array}{l}\text { Did you experience any barriers in encouraging functional } \\
\text { activities of older adults? } \\
\text { If yes, what were these barriers? }\end{array}$ \\
\hline Topics & $\begin{array}{l}\text { Examples of questions from the interviews with older adults and } \\
\text { their informal caregivers }\end{array}$ \\
\hline Fidelity & $\begin{array}{l}\text { Did the nurses encourage you to perform functional activities } \\
\text { independent? } \\
\text { If yes, can you amplify your answer? }\end{array}$ \\
\hline Dose received satisfaction & $\begin{array}{l}\text { How satisfied were you with how the nurses encouraged you (or } \\
\text { did not encourage you) to independently perform functional } \\
\text { activities? }\end{array}$ \\
\hline Context & $\begin{array}{l}\text { Did you experience any barriers in independently performing } \\
\text { functional activities? } \\
\text { If yes, what were these barriers? }\end{array}$ \\
\hline
\end{tabular}




\section{Additional File 5.2. Example of the checklist for reviewing the implementation plans}

\begin{tabular}{|c|c|c|c|c|}
\hline \multirow[t]{2}{*}{ Name } & \multirow[t]{2}{*}{ Requirements } & \multirow[b]{2}{*}{ Yes } & \multicolumn{2}{|r|}{ Comments } \\
\hline & & & No & \\
\hline $\begin{array}{l}\text { Step 1: Formulate a } \\
\text { proposal for change and } \\
\text { SMART (Specific, } \\
\text { Measurable, Attainable, } \\
\text { Relevant, Time-Bound) } \\
\text { goals. }\end{array}$ & $\begin{array}{l}\text { Has it described what must change? (A) } \\
\text { Has it described how much must change? (B) } \\
\text { Has it described who must change? (C) } \\
\text { Has it described when the change must } \\
\text { occur? (D) } \\
\text { Has a SMART goal been formulated based on } \\
\text { A, B, C and D? }\end{array}$ & $\begin{array}{l}x \\
x \\
x \\
x\end{array}$ & & \\
\hline $\begin{array}{l}\text { Step 2: Assess the } \\
\text { performance of } \\
\text { professionals in } \\
\text { encouraging functional } \\
\text { activities and related barrier } \\
\text { and formulating SMART } \\
\text { targets for change. }\end{array}$ & $\begin{array}{l}\text { Has the MAINtAIN-C questionnaire been } \\
\text { administered? } \\
\text { Has the Excel tool been completed? } \\
\text { Has it described the current performance of } \\
\text { professionals in encouraging functional } \\
\text { activities? } \\
\text { Has it described the barriers of professionals } \\
\text { in encouraging functional activities? } \\
\text { Have SMART goals been formulated based on } \\
\text { current performance and barriers? }\end{array}$ & $\begin{array}{l}x \\
x\end{array}$ & $x$ & $\begin{array}{l}\text { The goals are not } \\
\text { formulated SMART. }\end{array}$ \\
\hline $\begin{array}{l}\text { Step 3: Select and tailor } \\
\text { strategies. }\end{array}$ & $\begin{array}{l}\text { Have the implementation strategies been } \\
\text { described? } \\
\text { Has it described how the strategies are } \\
\text { tailored to the barriers? } \\
\text { Has it described who is responsible for } \\
\text { executing the strategies? }\end{array}$ & $x$ & & \\
\hline $\begin{array}{l}\text { Step 4: Plan the } \\
\text { implementation process. }\end{array}$ & $\begin{array}{l}\text { Has it described who is going to execute the } \\
\text { implementation of the strategies in practice? } \\
\text { Has it described who is involved during the } \\
\text { implementation? } \\
\text { Has it described how much and when the } \\
\text { strategies are executed? }\end{array}$ & $x$ & & \\
\hline $\begin{array}{l}\text { Step 5: Integrate the } \\
\text { improvement within } \\
\text { practice. }\end{array}$ & $\begin{array}{l}\text { Has it described which actions need to ensure } \\
\text { that the change is secured? } \\
\text { Has it specifically described who is executing } \\
\text { these actions and when? }\end{array}$ & $x$ & & \\
\hline $\begin{array}{l}\text { Step 6: Evaluate and revise } \\
\text { the plan. }\end{array}$ & $\begin{array}{l}\text { Has it described which actions are undertaken } \\
\text { to evaluate the implementation process? } \\
\text { Has it specifically described who is executing } \\
\text { these actions and when? }\end{array}$ & $x$ & & \\
\hline
\end{tabular}




\section{Additional File 5.3. Example of the checklist for the review of patient records}

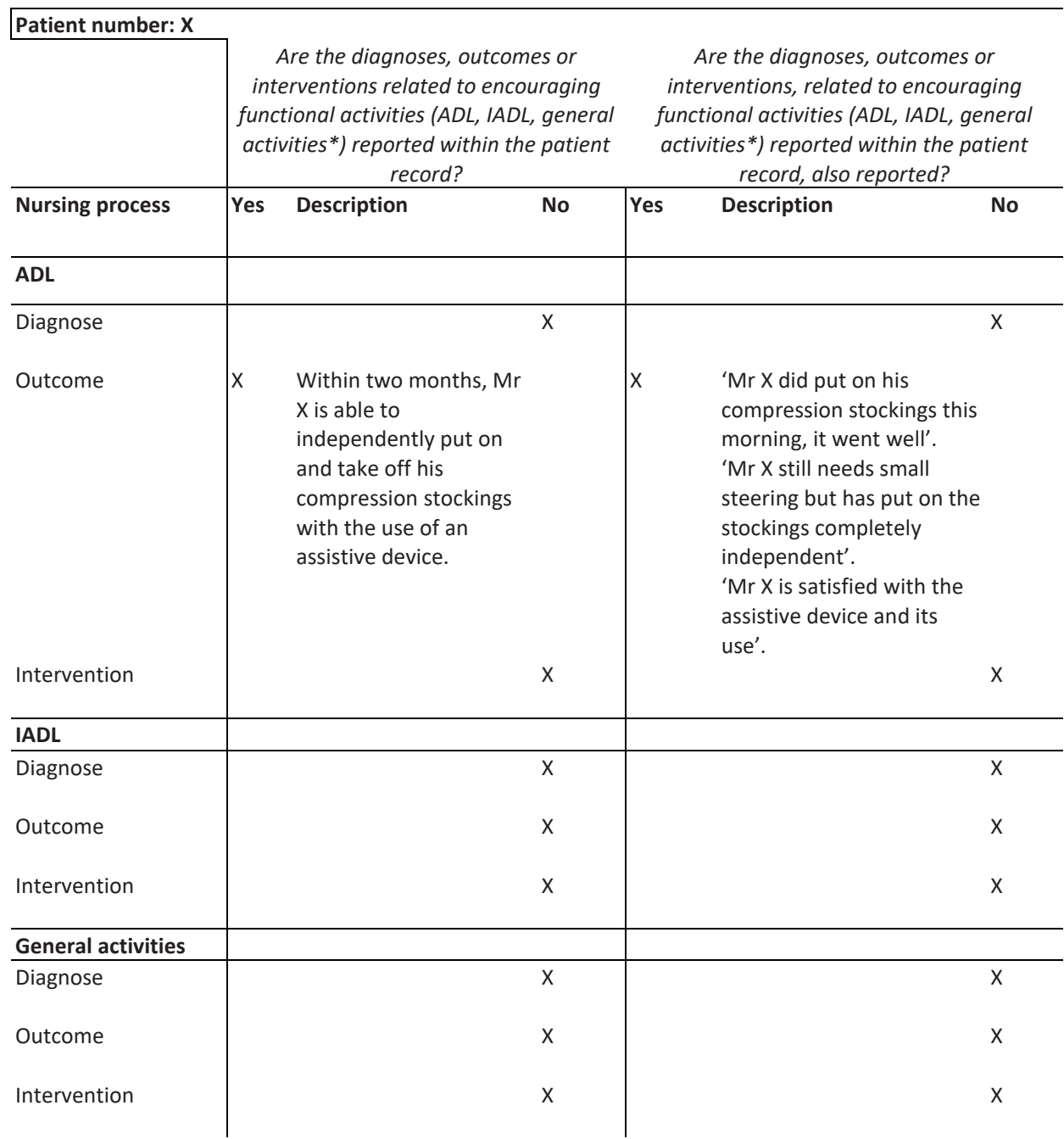

*We followed the clustering of the ADL (e.g. using the toilet) and IADL (e.g. preparing breakfast) as presented in the Groningen Activity Restriction Scale (GARS) developed to measure disability (28). For the definition of general activities (e.g. discussing with clients which activities they can still perform), we followed the activities as presented in the MAINtAIN-C Behaviours scale. ${ }^{15}$ 


\section{Additional File 5.4. Box 1. The planned implementation strategies of the community nurses as described in their implementation plans}

Box 1 The planned implementation strategies of the community nurses as described in their implementation plans.

\section{Implementation strategies}

- $\quad$ Different content and structure of team meetings: using case studies (discussing the process of encouraging functional activities for particular older adults), emphasising the use of informative media, sharing experiences and giving each other feedback

- Individual coaching (to share experiences with team members and encourage the provision of giving feedback)

- $\quad$ Providing information flyers to new clients on how to independently perform functional activities

- Having a conversation with the manager and the board of the organisation to discuss the development of information flyers, which can be provided to new clients on how to independently perform functional activities

- Providing a newsletter within the organisation about the programme and the importance of encouraging functional activities

- Providing clinical lessons to team members (together with an occupational therapist and physiotherapist about the importance of encouraging independent performance of functional activities and the use of assistive devices and with a mental health care worker to discuss mental problems of clients in relation to resistance to change)

- Having a conversation with the manager and the board of the organisation to provide clarity on the job description of community nurses related to their leadership role

- Appointing team members as opinion leaders (to lead by example, to motivate, inform and prioritise the encouragement of functional activities)

- $\quad$ Shadowing their team members during the provision of community care in practice (a community nurse, occupational therapist or opinion leaders should go along with the other team members to increase awareness, to learn from each other and to give feedback) 



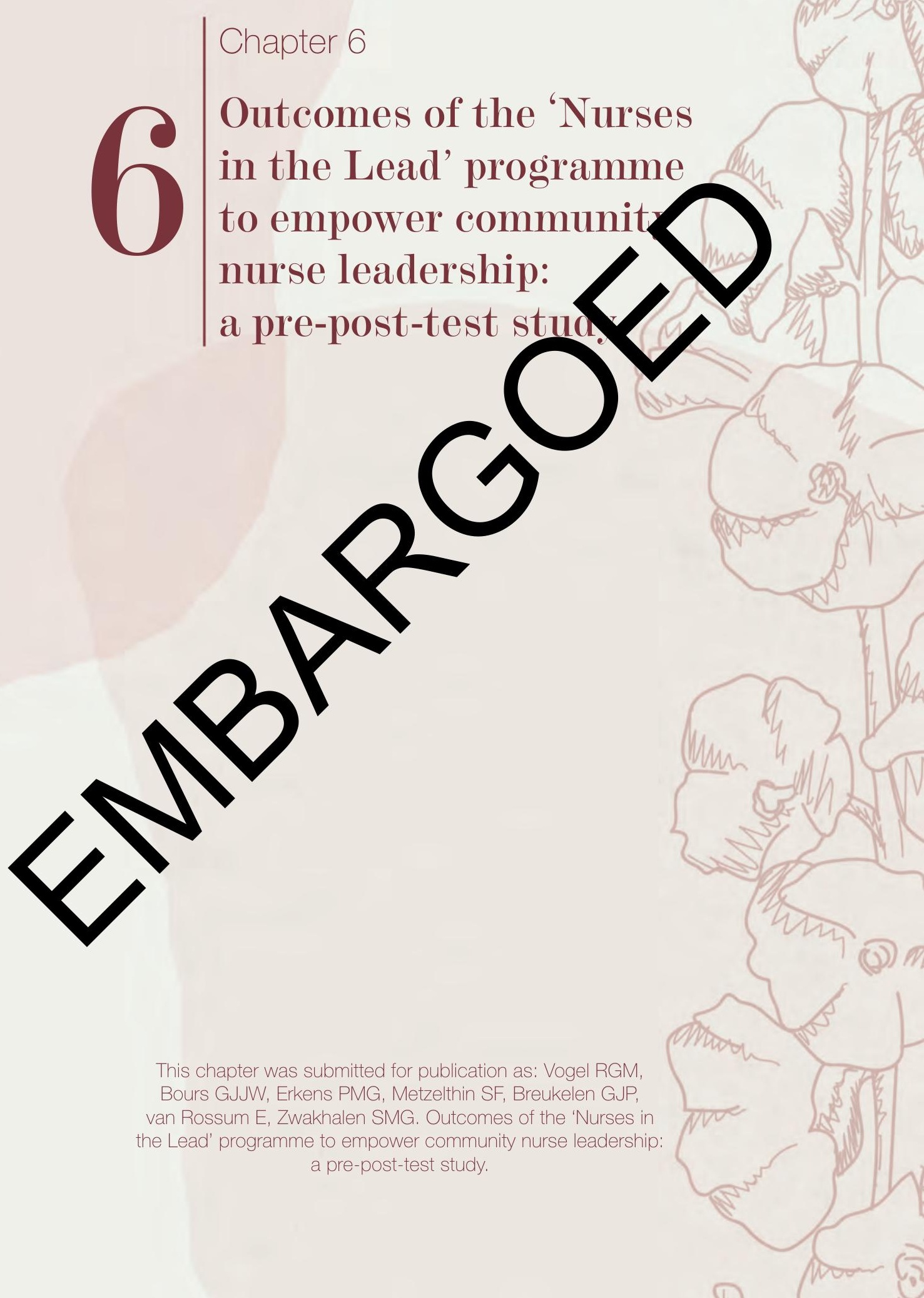


The main objective of this dissertation was to investigate the empowerment of community nurses in their leadership for implementing evidence. Specifically, this dissertation aimed to meet the following goals:

1) Provide insight into programmes to enhance the leadership of nursing staff in longterm care;

2) Develop a nurse leadership programme named Nurses in the Lead, for empowering community nurse leadership in implementing evidence targeted on encouraging functional activities;

3) Evaluate the leadership programme regarding leadership competencies of community nurses and the implementation processes of the programme in daily practice.

In this chapter, we present and discuss the main findings of this dissertation considering the strengths and limitations of our work and its implications for practice, future research and education.

\section{Main findings}

In our systematic review (Chapter 2), we identified three programmes on nurse leadership in community care. Of these, only one study reported on the outcomes in terms of processes and effects. We developed a new nurse leadership programme (Chapter 3) in close collaboration with community nurses (i.e. NitL) to empower community nurse leadership for implementing evidence. The programme contains a systematic approach of steps and tools to empower nurses to adopt evidence into practice and training to empower nurses in enabling team members to change their practice. One of the implementation tools was the Maastricht Nurses Activities Inventory for Community Care (MAINtAIN-C) questionnaire to measure the perceived behaviour and barriers of community care professionals in encouraging functional activities (Chapter 4). The NitL programme was implemented in practice among seven community nurses each in charge of 10-15 team members. A mixed-method formative process evaluation study (Chapter 5 ) showed NitL was largely executed as planned and perceived as worthwhile by community nurses and their team members. Programme adaptations, such as extending the training first, followed by the systematic approach and the implementation of evidence, were recommended to make NitL more promising for practice. We also evaluated the outcomes of the programme (Chapter 6) for community nurses and their team members. A pre-post-test evaluation showed NitL was promising and valuable for use in practice. Although no improvements in perceived leadership behaviour of community nurses were shown, significant improvements in the perceived behaviour in encouraging functional activities were identified for their team members. 


\section{Methodological considerations}

This section addresses the methodological considerations of our studies. Considerations that are discussed are related to: 1) tailoring of interventions, 2) evaluation of complex interventions and 3) the measurement and outcomes of nurse leadership.

\section{Tailoring of interventions}

Optimally, interventions are tailored to a specific context to suit the needs and characteristics of individuals in practice ${ }^{1}$. Since nurses with different educational levels and roles interact within the community care setting, interventions often consist of multiple components, target groups, and the evaluation of outcomes on different levels. Such interventions are complex according to the Medical Research Counsel ${ }^{2}$. NitL consists of two components tailored to the needs of the participating community nurses and evaluated both on the level of the community nurses and their team members. The disadvantage of tailored interventions is the lack of standardisation, which can cause difficulties in determining their effectiveness ${ }^{3}$. Context-related interventions, such as NitL, can also threaten external validity. One could question the transferability of an intervention in terms of whether it was developed for one setting and reproduced in another ${ }^{4}$. However, tailoring interventions to resemble daily practice as much as possible, rather than being standardised, may still be more effective, since behaviour change may be more likely to occur ${ }^{2}$. Therefore, we assume that this tailored approach contributed to the successful implementation of the NitL programme

\section{Evaluation of complex interventions}

Evaluating a complex intervention should address two aspects, namely evaluating whether the intervention is effective in terms of outcomes and how the components of the intervention work in practice ${ }^{2}$. We evaluated the outcomes of NitL by conducting a pre-post-test study and how the NitL programme was implemented into practice by conducting a process evaluation following the framework of Saunders et al. ${ }^{5}$. The prepost-test design made it difficult to attribute changes in outcomes to NitL since there was no random assignment and no control group, which made controlling for external factors difficult. This threatened the internal validity of our study, as change could have been due to maturation, for example ${ }^{6}$. However, we conducted the pre-post-test study as an early evaluation of NitL to establish if the programme was valuable for further research and integration into clinical practice. As such, we provided first insights into the outcomes of the programme and the related experiences of community nurses and their team members. This is important before conducting a randomised controlled trial to address the possible uncertainties first and to prevent high expenses and time commitment, which could have led to research waste. It was also difficult to conduct a full trial due to the limited resources in terms of money and time within our studies. 
The next step should be to develop NitL further and incorporate the adaptations to the programme as addressed in our studies, and specifically consider the tailored approach of the programme. Afterwards, a randomized controlled evaluation study should provide insights into the effects of NitL.

\section{Measurement and outcomes of nurse leadership}

Nurse leadership is conceptualised in various ways and measured with different instruments $^{7,8}$. For instance, in their review, Cummings et al. ${ }^{8}$ found 93 studies on nurse leadership that used 58 different measurement instruments. The most frequently used instrument was the Leadership Practices Inventory (LPI). To evaluate the outcomes of NitL, we also used the LPI based on the conceptual fit and its psychometric properties ${ }^{9,10}$. We should consider that this variety in leadership concepts and measurement instruments within the nursing field make it complicated to draw conclusions. Moreover, the heterogeneity of the instruments might impede the generalisability of the results. However, since leadership is mostly tailored to a specific setting, it is difficult to establish one overall definition and related measurement instrument. Therefore, when developing and evaluating nurse leadership, it is important to carefully consider the most optimal measurement instrument related to the conceptualisation of leadership in this context.

We used both quantitative and qualitative measurements to study community nurse leadership. LPI data were complemented by qualitative data to provide stronger evidence. This helps to answer Stentz et al. ${ }^{11}$ call for more mixed-method research to strengthen our understanding of leadership. By combining quantitative and qualitative methods, we could provide broader insight into our research questions ${ }^{12,13}$. We were also able to investigate possible contradictions between the quantitative and qualitative data. For example, our interviews with community nurses indicated they felt the programme helped to strengthen their leadership. However, quantitative changes in perceived leadership were not significant (notably, this could be due to the small sample size of community nurses in our study).

\section{Theoretical considerations}

In this section, we discuss theoretical considerations related to our results, related to: 1) the definition and operationalisation of leadership 2) programmes to empower leadership.

\section{The definition and operationalisation of leadership}

Growing evidence supports the positive impact of nurse leadership on patient, staff and organisational outcomes ${ }^{7,14,15}$. Within this dissertation, we adopted the definition of leadership by Heinen ${ }^{16}$ as 'a process where nurses can develop observable leadership 
competencies and attributes needed to improve patient outcomes, personnel outcomes and organisational outcomes'.

An increasing number of studies on nurse leadership have been published over the past decade ${ }^{15,17}$. Across studies, leadership has been conceptualised based on various styles, such as transformational leadership - the most frequently used approach within the nursing field ${ }^{17}$. Transformational leaders concentrate on building relationships and influencing and motivating others to bring about change ${ }^{18,19}$. Alternatively, professional leaders focus on coaching and supporting team members and advocating for the nursing profession ${ }^{17,20}$, and clinical leaders focus on influencing innovation and improvements and empowering patients and relatives to achieve care outcomes ${ }^{21,22}$. However, studies on leadership within the community care setting are scarce, since most studies are conducted in other settings, such as in the hospital. McKenna et al. ${ }^{23}$ concluded researchers disagree as to whether community nurse leadership even exists.

From a broader perspective, our operationalisation of leadership is in line with other studies conducted in different settings. We operationalised leadership as being able to both implement evidence and enable team members to use this evidence in practice. The systematic implementation of evidence can be viewed from the perspective of clinical leadership ${ }^{24}$. Enabling team members to change practice can be regarded as transformational leadership behaviours ${ }^{25}$ and could as well be viewed from the angle of professional leadership. Our operationalisation was consistent with the participating needs of community nurses in practice and the expectations as described by Rosendal ${ }^{26}$. Our study is one of the few published studies that concentrate primarily on a leadership programme for nurses in community care. For the future, it is important to expand our knowledge on the conceptualisation and operationalisation of community nurse leadership in practice

\section{Programmes to empower leadership}

Cummings et al. $^{8}$ stated that targeted interventions can be effective for developing nurse leadership in practice. Especially, interventions adapted to the specific needs of nurses can be valuable in improving nurse leadership ${ }^{27}$. An important aspect to consider is the context of an intervention since contextual factors can impact leadership practices ${ }^{8}$. Within our systematic review ${ }^{28}$, we detected only three published

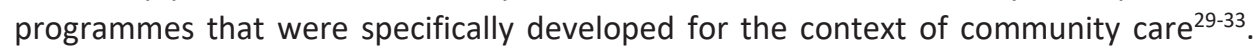
Within NitL, we focused on leadership for the systematic implementation of evidence, as quality improvement is characterised by the translation of results from research into practice $^{34}$ and leadership is vital to facilitate this translation ${ }^{35}$. When looking at the scope of the previously developed leadership programmes, only Gifford and colleagues focused on leadership for the implementation of evidence ${ }^{29-31}$ and combined transformational leadership development with clinical quality improvement. Although other studies in community care focused on quality improvement, this was often in 
reference to $\mathrm{EBP}^{36,37}$. The implementation of evidence and $\mathrm{EBP}$ are two concepts that are often linked and used interchangeably in other studies, as can also be seen in the systematic review of Valimaki et al. ${ }^{38}$.

\section{Future directions}

In this section, we discuss the implications of our studies for future practice, research and education.

\section{Practice}

NitL is a context-specific programme that combines elements of different leadership perspectives and is directed towards both the level of community nurses and their team members to align with the expected competencies of community nurses in practice. First, leadership of community nurses remains essential. Given the upcoming staff shortages and complexity of care, it is important to enhance community nurses' professional knowledge and skills to prepare them better for their roles ${ }^{39}$. Care organisations should promote leadership vision and guide the professionals in their organisation to move in this direction. They should clearly determine and communicate the position, responsibilities and competencies of community nurses. Community nurses should be involved in this process since their professional viewpoint can inform and strengthen the development of policy.

Second, organisations should continue to offer leadership programmes in practice. Such programmes may be strengthened by focusing on other key tasks of community nurses, such as EBP, diagnostic reasoning and inter-professional collaboration as proposed by Rosendal ${ }^{26}$. In this way, the Dutch National Quality Framework for Community Care is implemented further into Dutch community care practice. These programmes should be facilitated by other leaders within the organisation since the learning process of professionals can be promoted by team learning in practice and contribute to a common purpose ${ }^{40}$. Further, it is important to also offer specific leadership programmes to vocational-trained nurses and helping aids, as their role requires leadership in practice.

\section{Research}

First, it is important to expand our knowledge on community nurse leadership and how this leadership should be performed in practice. Consensus should be reached on using a clear, up-to-date and context-related conceptualisation and operationalisation of community nurse leadership. Optimal measurement instruments should be identified to measure this leadership. 
Second, we evaluated the NitL programme using a pre-post-test study, which provided valuable insights into the outcomes of the programme. However, we must further optimise the programme by incorporating the adaptations as recommended in our studies and investigating subsequent outcomes. Therefore, we recommend using a randomised and controlled evaluation study.

Third, it is relevant to investigate whether the programme is transferable to other health care settings. For example, professionals working within nursing homes and disability community living services also need leadership within daily practice ${ }^{41,42}$. It is vital to assess the specific needs of nurses within these settings to adhere to contextual factors.

\section{Education}

First, nurse education curricula should consider strengthening nursing students' leadership competencies so that newly graduated community nurses can apply these early in practice. Leadership competencies are learned over time, and growing within a leadership role starts early within education and can evolve ${ }^{43}$. Thus, it is important to address this at the vocational, bachelor and master levels, as nurse leadership is key for all educational levels. Notably, a distinction should be made between the competencies for these different levels as well as between those needed for new versus established employees. This also enables organisations in practice to empower the competencies of professionals with differentiation between vocationally trained nurses and bacheloreducated nurses and nurse practitioners.

Second, continuous attention should be paid to strengthening the competencies of students for implementing, evaluating and safeguarding evidence early, as the continuous implementation of evidence is necessary to improve the quality of care. 


\section{References}

1. Baker R, Camosso-Stefinovic J, Gillies C, Shaw EJ, Cheater F, Flottorp S, et al. Tailored interventions to address determinants of practice. Cochrane Database of Systematic Reviews. 2015(4).

2. Craig P, Dieppe P, Macintyre S, Michie S, Nazareth I, Petticrew M. Developing and evaluating complex interventions: the new Medical Research Council guidance. BMJ. 2008;337.

3. Beck C, McSweeney JC, Richards KC, Roberson PK, Tsai P-F, Souder E. Challenges in tailored intervention research. Nursing outlook. 2010;58(2):104-10.

4. Cambon L, Minary L, Ridde V, Alla F. Transferability of interventions in health education: a review. BMC public health. 2012;12(1):1-13.

5. Saunders RP, Evans MH, Joshi P. Developing a process-evaluation plan for assessing health promotion program implementation: a how-to guide. Health promotion practice. 2005;6(2):134-47.

6. Knapp TR. Why is the one-group pretest-posttest design still used? : SAGE Publications Sage CA: Los Angeles, CA; 2016.

7. Wong CA, Cummings GG, Ducharme L. The relationship between nursing leadership and patient outcomes: a systematic review update. Journal of nursing management. 2013;21(5):709-24.

8. Cummings GG, Lee S, Tate K, Penconek T, Micaroni SPM, Paananen T, et al. The essentials of nursing leadership: A systematic review of factors and educational interventions influencing nursing leadership. International journal of nursing studies. 2020:103842.

9. Posner BZ, Kouzes JM. Psychometric properties of the leadership practices inventory-updated. Educational and Psychological Measurement. 1993;53(1):191-9.

10. Kouzes JM, Posner BZ. The leadership practices inventory (LPI): Self instrument: John Wiley \& Sons; 2003.

11. Stentz JE, Clark VLP, Matkin GS. Applying mixed methods to leadership research: A review of current practices. The leadership quarterly. 2012;23(6):1173-83.

12. Petticrew M, Rehfuess E, Noyes J, Higgins JP, Mayhew A, Pantoja T, et al. Synthesizing evidence on complex interventions: how meta-analytical, qualitative, and mixed-method approaches can contribute. Journal of clinical epidemiology. 2013;66(11):1230-43.

13. Creswell JW. A concise introduction to mixed methods research: SAGE publications; 2014.

14. Boamah SA, Laschinger HKS, Wong C, Clarke S. Effect of transformational leadership on job satisfaction and patient safety outcomes. Nursing outlook. 2018;66(2):180-9.

15. Cummings GG, Tate K, Lee S, Wong CA, Paananen T, Micaroni SPM, et al. Leadership styles and outcome patterns for the nursing workforce and work environment: A systematic review. International journal of nursing studies. 2018;85:19-60.

16. Heinen $M$, van Oostveen $C$, Peters J, Vermeulen $H$, Huis A. An integrative review of leadership competencies and attributes in advanced nursing practice. Journal of advanced nursing. 2019;75(11):2378-92.

17. Vermeulen H, Holleman, G., Huis, A., Ista, E., Lalleman, P. Verpleegkundig Leiderschap (BOEK). Houten: Bohn Stafleu van Loghum 2017.

18. Bass BM. Two decades of research and development in transformational leadership. Eur J Work Organ Psy. 1999;8.

19. Giddens J. Transformational leadership: What every nursing dean should know. Journal of Professional Nursing. 2018;34(2):117-21.

20. van der Cingel M, van den Pol-Grevelink A. 'Leadership in daily practice'. TVZ-Verpleegkunde in praktijk en wetenschap. 2020;130(2):32-5.

21. Joseph ML, Huber DL. Clinical leadership development and education for nurses: prospects and opportunities. Journal of healthcare leadership. 2015;7:55.

22. Adriaansen M, Peters J. Leiderschapsontwikkeling van verpleegkundigen (BOEK). Houten: Bohn Stafleu Van Loghum; 2018.

23. McKenna H, Keeney S, Bradley M. Nurse leadership within primary care: the perceptions of community nurses, GPs, policy makers and members of the public. Journal of Nursing Management. 2004;12(1): 69-76.

24. Brown A, Dewing J. The next generation of clinical leaders; future proofing preparation. Journal of nursing management. 2016;24(5):569-70. 
25. Farahnak LR, Ehrhart MG, Torres EM, Aarons GA. The influence of transformational leadership and leader attitudes on subordinate attitudes and implementation success. Journal of Leadership and Organizational Studies. 2020;27(1):98-111.

26. Rosendal H. Expertisegebied Wijkverpleegkundige [Community Nurses' Area of Expertise]: V\&VN; 2019.

27. Galuska LA. Education as a springboard for transformational leadership development: Listening to the voices of nurses. The Journal of Continuing Education in Nursing. 2014;45(2):67-76.

28. Erkens PMG, Vogel RGM, van Rossum E, Metzelthin SF, Meijers JMM, Zwakhalen SMG, et al. Nurse leadership in long-term care: a systematic review on leadership programmes. Manuscript submitted for publication.

29. Gifford. WA, Davies B, Graham ID, Lefebre N, Tourangeau A, Woodend K. A mixed methods pilot study with a cluster randomized control trial to evaluate the impact of a leadership intervention on guideline implementation in home care nursing. Implementation science : IS. 2008;3:51.

30. Gifford. WA, Davies BL, Tourangeau A, Lefebre N. Developing team leadership to facilitate guideline utilization: Planning and evaluating a 3-month intervention strategy. Journal of Nursing Management. 2011;19(1):121-32.

31. Gifford. WA, Davies BL, Graham ID, Tourangeau A, Woodend AK, Lefebre N. Developing leadership capacity for guideline use: A pilot cluster randomized control trial. Worldviews on Evidence-Based Nursing. 2013;10.

32. Sams D. The development of leadership skills in clinical practice. Nursing times. 1996;92(28):37-9.

33. Roberson C. Development and delivery of a clinical leadership programme for integrated community teams. British Journal of Community Nursing. 2019;24(11):518-22.

34. Bianchi M, Bagnasco A, Bressan V, Barisone M, Timmins F, Rossi S, et al. A review of the role of nurse leadership in promoting and sustaining evidence-based practice. Journal of nursing management. 2018;26(8):918-32.

35. Grol R, Wensing M, Eccles M, Davis D. Improving patient care: The Implementation of Change in Health Care. Hoboken, New Jersey: John Wiley \& Sons; 2013.

36. Li S, Cao M, Zhu X. Evidence-based practice: Knowledge, attitudes, implementation, facilitators, and barriers among community nurses - systematic review. Medicine. 2019;98(39).

37. Pereira F, Pellaux V, Verloo H. Beliefs and implementation of evidence-based practice among community health nurses: A cross-sectional descriptive study. Journal of Clinical Nursing. 2018;27(910):2052-61.

38. Valimaki T, Partanen P, Haggman-Laitila A. An Integrative Review of Interventions for Enhancing Leadership in the Implementation of Evidence-Based Nursing. Worldviews Evid Based Nurs. 2018;15(6):424-31.

39. Shields MA, Ward M. Improving nurse retention in the National Health Service in England: the impact of job satisfaction on intentions to quit. Journal of health economics. 2001;20(5):677-701.

40. Nembhard IM, Edmondson AC. Making it safe: the effects of leader inclusiveness and professional status on psychological safety and improvement efforts in health care teams. J Organ Behav. 2006;27.

41. Zonneveld N, Pittens C, Minkman M. Appropriate leadership in nursing home care: a narrative review. Leadership in Health Services. 2021.

42. Bowen CN, Havercamp SM, Bowen SK, Nye G. A call to action: Preparing a disability-competent health care workforce. Disability and Health Journal. 2020;13(4):100941.

43. Hamric AB, Spross JA, Hanson CM. Advanced nursing practice: An integrative approach: WB Saunders Company; 2014. 



\section{Summary}

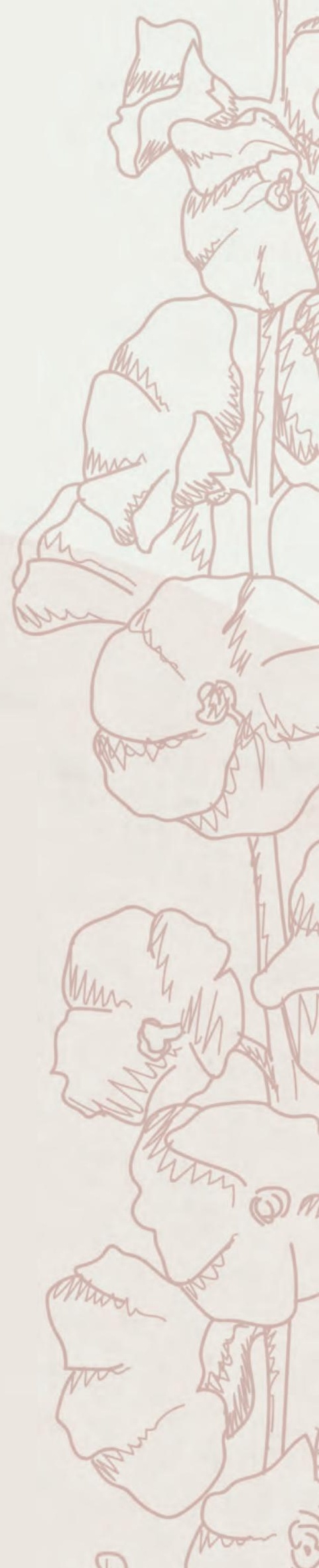


Community nurses have an important role in Dutch community care: they lead care teams, establish the care needs of clients, deliver care while improving clients' independence and translate research evidence into practice to improve care outcomes. This requires leadership. The main objective of this dissertation was to study the empowerment of community nurses in their leadership for implementing evidence. Specifically, this dissertation aimed to:

1) Provide insight into programmes to enhance the leadership of nursing staff in longterm care;

2) Develop a nurse leadership programme named Nurses in the Lead, for empowering community nurse leadership in implementing evidence targeted on encouraging functional activities;

3) Evaluate the leadership programme regarding leadership competencies of community nurses and the implementation processes of the programme in daily practice.

In Chapter 1, we first introduce the current challenges within Dutch community care, the different professions within the setting and the organisation of care. We also address the role and function of the community nurse. Next, we report on the relevance, conceptualisation and importance of nurse leadership for improving nursing outcomes. Lastly, we present an overview of the relevance and operationalisation of leadership for the implementation of evidence and introduce the NitL programme.

Chapter 2 provides an introduction to our systematic review on existing leadership programmes to improve the leadership of nursing staff in long-term care. We included 13 studies out of the 3300 screened titles and abstracts, describing 11 leadership programmes. Of these 13 studies, 6 were conducted in nursing homes, 3 in community care, 1 in a geriatric rehabilitation care facility and 1 non-specified long-term care setting. Most of the programmes $(n=8)$ focused on strengthening transformational leadership, and some programmes $(n=3)$ combined the empowerment of transformational leadership with clinical leadership. Most programmes focused on the leadership of registered nurses, whereas other programmes also focused on the leadership of vocational nurses and care aides. Five of the included nursing leadership programmes reported findings from both process and effect evaluations. However, weaknesses in these studies were found related to the research design, sample sizes and data collection. Therefore, it remains difficult to conclude the effects of these programmes.

In Chapter 3, we present our developed leadership programme, named NitL. The programme was developed in collaboration with community nurses $(n=7)$ and research experts $(n=4)$ and consists of two components. First, the programme contains a systematic approach with implementation steps and tools to empower the community nurses in implementing evidence. This evidence was targeted at encouraging functional 
activities of older adults and was offered via a web-based e-learning platform. The six implementation steps guided the community nurses in systematically creating an implementation plan. To complete the steps, several practical implementation tools were included, such as a template for developing an implementation plan. The second component consisted of training to empower the community nurses in enabling team members to change their practice with a focus on motivational interviewing, influencing behaviour, dealing with resistance to change and coaching. The training was a blend of 4-hour face-to-face group training and background theory offered via web-based e-learning. The NitL programme was designed to operate for 8 months. During the first 2 months, the nurses created an implementation plan by utilizing the systematic approach. The nurses created an implementation plan, while receiving support via bimonthly meetings with an interventionist. The next 6 months, the nurses implemented these plans, while receiving group training and utilizing the E-Learning programme.

Chapter 4 provides insight into a promising questionnaire that community nurses can use to measure the behaviour and barriers of the nurses in their teams in encouraging functional activities. First, community nurses $(n=7)$ assessed the MAINtAIN questionnaire, which was developed for the nursing home setting, in terms of its appropriateness and feasibility for their particular context. Based on the evaluation, the formulation and verbiage of the MAINtAIN were adapted, with some items being excluded and relevant items added, resulting in the MAINtAIN-C for community care. Thereafter, the MAINtAIN-C was assessed on content validity by research experts $(n=9)$ and community care professionals $(n=18)$. The MAINtAIN-C showed good content validity. Second, the psychometric properties of the adapted MAINtAIN-C were assessed by community care professionals $(n=80)$. Construct validity was evaluated using exploratory factor analysis (EFA) and internal consistency was determined by calculating Cronbach's alpha. This resulted in the final MAINtAIN-C questionnaire, consisting of two scales, both of which showed good internal consistency. The Behaviours scale (20 items) measures perceived behaviour in encouraging functional activities $(\alpha=.92)$. The Barriers scale measures barriers in encouraging functional activities related to two dimensions: 1 ) the clients' context ( 7 items; $\alpha=.78$ ) and 2) professional, social and organisational contexts (21 items; $\alpha=.83$ ). The MAINtAIN-C can be used to detect the behaviour of the nurses and develop strategies for encouraging functional activities among older adults.

In Chapter 5, we present a mixed-methods formative process evaluation, with a predominantly qualitative approach. Qualitative data were collected by interviews with seven community nurses, focus groups with 31 team members and we reviewed seven implementation plans and 28 patient records. Quantitative data were collected by using the MAINtAIN-C questionnaire among community nurses and team members $(n=90)$. The results show that NitL was largely implemented as planned, however points of concern were the use and perceived relevance of the theory within the training, the 
realization of the implementation plans and the reporting in the records of the patients. Barriers for taking a leading role and encouraging functional activities of older adults were time shortages, and the complexity of care. Facilitating factors in this process were guidance, structure and effective communication. The community nurses found the systematic approach functional and the training educational to develop their role further. Most team members found NitL useful and were satisfied with the received coaching by the community nurses. To strengthen NitL, the nurses recommended providing the training first, before offering the systematic approach and implementing evidence, and extending the duration of the training. The team members recommended continuing the clinical lessons in practice, which was offered to them as an implementation strategy from the community nurses. Conclusively, the NitL programme appears worthwhile for further implementation in practice, and we conclude the chapter by recommending adaptations to make it more valuable for practice.

Chapter 6 provides insight into the evaluation of the NitL programme in terms of changes in community nurses' leadership behaviour and behaviour in encouraging functional activities by their team members. We conducted a mixed-method pre-posttest study using a predominantly quantitative approach. Quantitative data were collected via questionnaires with community nurses $(n=7)$ and team members $(n=83)$. Primary outcomes were perceived leadership behaviour and perceived behaviour in encouraging functional activities. Qualitative data were collected via interviews with community nurses $(n=7)$ and focus groups with team members $(n=31)$ regarding changes in community nurses' leadership behaviour and team members' behaviour in encouraging functional activities. Our results indicated that no significant improvements in community nurses' leadership behaviour could be demonstrated, but such improvements were found in team members' behaviour. The community nurses indicated that the programme increased their leadership awareness and most team members confirmed changes in their behaviour. Conclusively, the programme was perceived as valuable and seems promising for use in practice; however, further testing with a larger sample is needed to further understand its impact. Overall, we concluded the programme could contribute to leadership development and serve as a guide for further research on the empowerment of community nurse leadership.

Our general discussion in Chapter 7 summarises the main findings of this dissertation. Further, we discuss the methodological considerations related to the tailoring and evaluation of complex interventions and measurements and outcomes of nurse leadership. We also discuss theoretical aspects in light of the definition and operationalisation of leadership and programmes to empower leadership. Finally, we provide implications for practice, research and education. 


Wijkverpleegkundigen vervullen een belangrijke rol in de Nederlandse thuiszorg. Zij leiden zorgteams, stellen de zorgbehoeften van cliënten vast en stimuleren daarbij de onafhankelijkheid van cliënten. Ook vertalen ze evidence naar de praktijk om de zorg te verbeteren. Dit complexe samenspel van rollen vereist leiderschap. Het hoofddoel van dit proefschrift was onderzoeken hoe het leiderschap van wijkverpleegkundigen, gericht op het implementeren van evidence, versterkt kan worden.

Dit proefschrift heeft een aantal subdoelen in het bijzonder:

1) Inzicht bieden in bestaande programma's om leiderschap van verpleegkundigen in de langdurige zorg te versterken;

2) Ontwikkelen van een leiderschapsprogramma voor wijkverpleegkundigen, genaamd Nurses in the Lead, om leiderschap van wijkverpleegkundigen te versterken, toegepast op het implementeren van evidence voor het stimuleren van functionele activiteiten;

3) Evalueren van dit leiderschapsprogramma, gericht op veranderingen in het leiderschapsgedrag van wijkverpleegkundigen en het implementatie proces van het programma in de dagelijkse praktijk.

In Hoofdstuk 1 introduceren we eerst de huidige uitdagingen binnen de Nederlandse wijkverpleging en de organisatie van de wijkverpleegkundige zorg. Ook gaan we in op de rol en functie van de wijkverpleegkundige. Vervolgens beschrijven we de relevantie, de conceptualisering en het belang van verpleegkundig leiderschap voor het verbeteren van verpleegkundige uitkomsten. Ten slotte beschrijven we de relevantie van leiderschap voor de implementatie van evidence en introduceren we het Nurses in the Lead (NitL) programma.

Hoofdstuk 2 geeft inzicht in een systematische review naar bestaande leiderschapsprogramma's voor verpleegkundigen in de langdurige zorg. We vonden 11 programma's, uit een totaal van 3300 gescreende artikelen. Van deze 11 programma's zijn er zes uitgevoerd in verpleeghuizen, drie in de thuiszorg, een in een geriatrische revalidatiezorginstelling en een in een niet-gespecificeerde langdurige zorgsetting. De meeste programma's $(n=8)$ waren gericht op het versterken van transformationeel leiderschap, en sommige programma's $(n=3)$ combineerden het versterken van transformationeel leiderschap met klinisch leiderschap. De meeste programma's waren gericht op leiderschap van hbo-gediplomeerde verpleegkundigen, terwijl andere programma's zich ook richtten op het leiderschap van mbo-verpleegkundigen en verzorgenden. Vijf van de opgenomen programma's voor verpleegkundig leiderschap rapporteerden bevindingen van zowel proces- als effectevaluaties. De methodologische kwaliteitsbeoordeling toonde zwaktes in onderzoeksopzet, steekproefomvang en gegevensverzameling. Het blijft daarom moeilijk om goed gefundeerde uitspraken te doen over de effecten van deze programma's. 
In Hoofdstuk 3 presenteren we ons ontwikkelde leiderschapsprogramma, genaamd Nurses in the Lead (NitL). Het programma is gebaseerd op eerder onderzoek en ontwikkeld in samenwerking met wijkverpleegkundigen $(n=7)$ en onderzoeks-experts $(n=4)$. Het bestaat uit twee componenten. De eerste component is een methodiek met implementatiestappen en tools om de wijkverpleegkundigen in staat te stellen om evidence te implementeren. De evidence is gericht op het stimuleren van functionele activiteiten van ouderen en is aangeboden via een E-Learning programma. De implementatiestappen ondersteunen de wijkverpleegkundigen in het systematisch ontwikkelen van een implementatieplan. Om de zes implementatiestappen te voltooien, zijn verschillende praktische implementatietools opgenomen, zoals een sjabloon voor het ontwikkelen van een implementatieplan. De tweede component van het programma bestaat uit training voor wijkverpleegkundigen, zodat zij teamleden kunnen ondersteunen bij het doorvoeren van veranderingen in de praktijk. De training richt zich op motiverende gespreksvoering, gedragsbeïnvloeding en omgaan met weerstand tegen verandering. De training is een mix van 4 uur groepstraining en achtergrondtheorie, en wordt aangeboden via het E-Learning programma. Het NitL-programma is ontwikkeld om gedurende acht maanden te worden geïmplementeerd. Gedurende de eerste 2 maanden stellen de wijkverpleegkundigen een implementatieplan op, door gebruik te maken van de methodiek. Zij krijgen daarbij ondersteuning van een ervaren trainer. De volgende 6 maanden voeren de verpleegkundigen het implementatieplan uit in de praktijk, terwijl ze groepstraining volgen en de achtergrondinformatie kunnen inzien.

Hoofdstuk 4 geeft inzicht in de Maastricht Nurses Activities Inventory for Community Care (MAINtAIN-C) vragenlijst, welke gebruikt kan worden om gedrag en barrières van verpleegkundigen in het stimuleren van functionele activiteiten van ouderen, te meten. De MAINtAIN-vragenlijst was oorspronkelijk ontwikkeld voor het verpleeghuis. De lijst werd door wijkverpleegkundigen $(n=7)$ beoordeeld op geschiktheid en haalbaarheid voor de wijkverpleging. Op basis hiervan werd de formulering van deze lijst aangepast, waarbij enkele items werden weggelaten en relevante items werden toegevoegd. Dit resulteerde in de MAINtAIN-C voor de wijkverpleging. Vervolgens is deze lijst beoordeeld op inhoudsvaliditeit door onderzoeks-experts $(n=9)$ en professionals in de thuiszorg $(n=18)$. De MAINtAIN-C toonde een goede inhoudsvaliditeit. Ten tweede werden de psychometrische eigenschappen van de MAINtAIN-C vastgesteld, door het afnemen van de vragenlijst bij verpleegkundigen en verzorgenden $(n=80)$. Constructvaliditeit werd geëvalueerd met behulp van verkennende factoranalyse (EFA) en de interne consistentie werd bepaald door de Cronbach's alpha te berekenen. Dit resulteerde in de uiteindelijke MAINtAIN-C, bestaande uit twee schalen, die beide een goede interne consistentie vertonen. De MAINtAIN-C Behaviours (20 items) meet ervaren gedrag bij het stimuleren van functionele activiteiten ( $\alpha=.92)$. De MAINtAIN-C Barriers meet barrières bij het stimuleren van functionele activiteiten, met betrekking tot twee dimensies: 1 ) de context van de cliënt (7 items; $\alpha=.78$ ) en 2) professionele, sociale en organisatorische context (21 items; $\alpha=.83$ ). 
In Hoofdstuk 5 presenteren we een mixed-methods formatieve procesevaluatie van het NitL-programma. De benadering was overwegend kwalitatief. Kwalitatieve gegevens werden verzameld door interviews met zeven wijkverpleegkundigen, focusgroepen met 31 teamleden en we beoordeelden zeven implementatieplannen en 28 patiëntendossiers. Kwantitatieve gegevens werden verzameld met behulp van de MAINtAIN-Cvragenlijst bij wijkverpleegkundigen en teamleden $(n=90)$. De resultaten laten zien dat NitL grotendeels is geïmplementeerd zoals gepland. Aandachtspunten waren het gebruik en de ervaren relevantie van de theorie binnen de training, de realisatie van de implementatieplannen en de rapportage in de patiëntendossiers. Belemmeringen voor het nemen van een leidende rol door wijkverpleegkundigen en het stimuleren van functionele activiteiten bij ouderen, waren tijdgebrek en de complexiteit van de zorg. Faciliterende factoren in dit proces waren begeleiding, structuur en effectieve communicatie. De wijkverpleegkundigen vonden de methodiek functioneel en de training leerzaam om hun rol verder te ontwikkelen. De meeste teamleden vonden NitL zinvol en waren tevreden over de begeleiding door de wijkverpleegkundigen. Om NitL te versterken, adviseerden de wijkverpleegkundigen om eerst de training aan te bieden, alvorens de methodiek aan te bieden. Ook adviseerden zij om de duur van de training te verlengen. De teamleden adviseerden om de klinische lessen in de praktijk voort te zetten, die hen als implementatiestrategie werd aangeboden. Concluderend lijkt het NitL-programma (met enige aanpassingen) veelbelovend voor verdere implementatie in de praktijk.

Hoofdstuk 6 geeft inzicht in de evaluatie van het NitL-programma, gericht op veranderingen in het leiderschapsgedrag van wijkverpleegkundigen en in het gedrag van teamleden in het stimuleren van functionele activiteiten. We hebben een pre-postmixed-methods evaluatie uitgevoerd. De benadering was overwegend kwantitatief. Primaire uitkomsten waren ervaren leiderschapsgedrag en ervaren gedrag in het stimuleren van functionele activiteiten. Kwantitatieve gegevens werden verzameld middels vragenlijsten, zoals de Leadership Practice Inventory (LPI) bij wijkverpleegkundigen ( $n=7$ ) en de MAINtAIN-C bij teamleden ( $n=83$ ). Kwalitatieve gegevens werden verzameld via interviews met wijkverpleegkundigen $(n=7)$ en focusgroepen met teamleden $(n=31)$. Onze resultaten gaven aan dat er geen statistisch significante verbeteringen in het leiderschapsgedrag van wijkverpleegkundigen konden worden aangetoond. Dergelijke verbeteringen werden wel gevonden in het gedrag van teamleden. De wijkverpleegkundigen gaven aan dat het programma hun leiderschapsbewustzijn verhoogde en de meeste teamleden bevestigden veranderingen in hun gedrag. Concluderend werd het programma als waardevol ervaren en lijkt het veelbelovend voor gebruik in de praktijk; verder testen met een grotere steekproef is echter nodig om hier meer zekerheid over te verkrijgen.

Onze algemene discussie in Hoofdstuk 7 vat de belangrijkste bevindingen van dit proefschrift samen. Methodologische overwegingen die in dit hoofdstuk worden 
besproken zijn het personaliseren en evalueren van complexe interventies en het meten van verpleegkundig leiderschap. Daarnaast worden theoretische overwegingen in dit hoofdstuk beschreven, gericht op de definitie en de operationalisering van leiderschap, en de beschikbare programma's om leiderschap te versterken. Tot slot beschrijven we de implicaties voor de praktijk, het onderzoek en het onderwijs. 

The studies reported in this dissertation provide insights into available interventions to enhance nurse leadership and the development, implementation and evaluation of a new leadership programme to empower community nurse leadership. This chapter addresses the impact of our studies on science, practice and education. We also describe the societal impact and efforts for further dissemination.

\section{Scientific impact}

The findings of our review emphasise the scarcity of available evidence and underline the importance of researching leadership within the community care setting. This dissertation also provides insight into the characteristics of community nurses and team members in changing their practice and a valid and reliable questionnaire to measure the behaviour and barriers of community care professionals in encouraging functional activities. Our findings led to discussions with editors, reviewers and peerreviewers of scientific journals about the conceptualisation of community nurse leadership and the scarcity of studies on this topic. The results have been presented and published (inter)nationally, which could have had an impact on the awareness of the importance of community nurse leadership. We believe this could have further motivated other researchers to investigate the operationalisation and implementation of community nurse leadership.

In collaboration with a third community care organisation, the NitL programme was further developed and implemented as part of the funding call 'Verpleging en Verzorging - beschrijven goede voorbeelden (project number 10040012010009)' of ZonMW (The Netherlands Organisation for Health Research and Development). During this project, 10-12 experienced community nurses were trained to implement the programme within their organisations. An extensive NitL train-the-trainer manual was developed and tested, which particularly focused on nurse leadership for coaching and supporting team members as well as clinical reasoning, applying evidence-based practice and advocating the needs of clients. By training community nurse leaders to lead and implement the NitL programme, their professional and didactic expertise was transferred to the participating organisations with the great advantage that the programme was permanently embedded within the organisations. Another call for funding is currently in progress to implement this enhanced NitL programme in practice. The programme will be implemented twice within two community care organisations, for circa 40 community nurses and 400 team members. First, the NitL programme will be implemented in the train-the-trainer form to secure the knowledge and expertise in the organisation, after which the trainers will independently oversee the programme. Finally, a more generic description of the NitL programme will be developed for nurses working in other long-term care sectors, such as nursing home care and mental health care and for other functions (e.g. vocational-trained nurses and social workers). 


\section{Impact on practice development}

One can create an impact on practice by actively involving the target group within the research. The NitL programme was developed, implemented and evaluated in close collaboration with the board of community care organisations, community nurses and representatives of clients receiving community care. The needs of the participating community nurses in practice were incorporated to develop our leadership programme. By gathering their views, the programme was made more suitable for practice. This research was initially conducted at the request of the board of two community care organisations, as they found it important to strengthen the leadership role of nurses in practice. Therefore, the findings of our studies were directly embedded into practice. The directors and managers of the care organisations were involved as members of an advisory board to incorporate the developments within the field and their organisations. Client representatives were also members of this advisory board and shared their ideas on our research. These individuals were actively involved in the content development and implementation of our programme.

Over the past years, we led several presentations and discussions about the role and importance of community nurse leadership and the findings of our research. During several presentations for other community care organisations, the NitL programme was introduced to (community) nurses, policy-makers, managers and care directors. This may have helped and inspired professionals of other community care organisations to create a vision and policy on community nurse' leadership and may have helped to recognise the importance of empowering community nurse leadership in practice. As noted above, the NitL programme has been further developed and implemented in collaboration with two additional community care organisations.

\section{Educational impact}

Developing leadership competencies is a continuous process that begins within early nursing education ${ }^{1}$. The findings of this dissertation were integrated into students' education and nursing curricula. We gave many lectures to students of the bachelor of nursing programme at Zuyd University of Applied Sciences, where leadership is embedded as a central theme. We also presented the findings of our studies during symposia, such as for nursing alumni at Zuyd University of Applied Sciences. Further, several students were involved with our research by writing assignments and theses about community nurse leadership. Moreover, we offered a minor, named NitL, to nursing students to strengthen their leadership competencies. This triggered awareness among students on the importance of their (upcoming) role in practice and contributed to the development of their vision on nurse leadership.

Further, a module on nurse leadership was developed for the bachelor of nursing programme duaal ouderenzorg at Zuyd University. We organised teaching days on nurse leadership for these students in collaboration with community care 
organisations. Moreover, through the development and implementation of the NitL programme within a third community care organisation, we ensure that community nurses are educated, trained and prepared for their leadership role in the context of continuous professional development.

\section{Societal impact}

The important role of community nurses has received major attention in the Netherlands over the past years. For instance, the Dutch National Quality Framework for Community Care ${ }^{2}$ was developed to ensure high-quality community care, by focusing amongst others on the important leadership role of community nurses. We believe the findings in this dissertation had an impact on national organisations and institutions. In particular, through our studies, the participating community nurses implemented the content of the Dutch National Quality Framework for Community Care into practice.

Further, since a policy advisor of V\&VN (the Dutch Nurses' Association) was involved as a member of the advisory board during our study, the findings of this thesis were directly disseminated to V\&VN. The advisory board members helped to create visibility of the project and awareness of community nurse leadership among national professional organisations, such as V\&VN. Further, we attended meetings of the Wetenschappelijke Tafel Wijkverpleging, which was initiated in 2019 to generate knowledge and work on the scientific underpinning of community care provision. We attended meetings with community nurses, researchers, educators and policy-makers with a background in community nursing. In this way, we were able to discuss the topic of community nurse leadership and share our findings on its importance for community care. Moreover, we were involved within the European Academy of Nursing Science, which is a scientific community in Europe for collaboration on research in nursing. This platform provided opportunities to discuss community nurse leadership and our findings with other nurse scientists. We were also able to meet with other researchers to develop and promote knowledge on this topic throughout Europe.

\section{Dissemination of findings}

The findings of this dissertation were disseminated in several ways. First, our research was embedded within the Living Lab in Ageing and Long-Term Care located in the southern part of the Netherlands. This Living Lab is a formal multidisciplinary network between Maastricht University, nine long-term care organisations, Gilde Intermediate Vocational Training Institute, VISTA College (secondary vocational education) and Zuyd University of Applied Sciences, all located in the southern part of the Netherlands. The collaboration with these organisations and institutes provided opportunities to share the findings of our research and create awareness on our topic. For instance, the NitL programme was further developed and implemented in collaboration with another 
community care organisation involved within the Living Lab. Furthermore, in 2019, a NitL symposium took place to disseminate our findings to the stakeholders involved in our research and other professionals. The symposium was attended by 65 professionals, including approximately 50 community nurses from the organisations affiliated with the Living Lab. Further, a participating organisation held a symposium for employed professionals during which three community nurses involved with our research shared their experiences with NitL and their role in practice.

Moreover, our findings have been shared via various media outlets, such as newsletters from ZonMw (the Netherlands Organization for Health Research and Development). Our results have also been published in three peer-reviewed international scientific journals. Further, we presented our results in the Dutch, practice-oriented journal TVZ Verpleegkundige Praktijk en Wetenschap. We also presented our findings at several scientific national and international conferences, such as the 3rd CARE4 - International Scientific Nursing and Midwifery Congress in Leuven and the 1st International Conference of the German Society of Nursing Science in Berlin. 


\section{References}

1. Hamric AB, Spross JA, Hanson CM. Advanced nursing practice: An integrative approach: WB Saunders Company; 2014.

2. Steering Committee National Quality Framework for Community Care (Stuurgroep Kwaliteitskader Wijkverpleging). National Quality Framework for Community Care (Kwaliteitskader Wijkverpleging). 2018. 


Het is gelukt, mijn proefschrift is af. Ik ben blij en trots, dat ik als verpleegkundige verder onderzoek ben gaan doen. Graag wil ik de mensen bedanken die hieraan hebben bijgedragen.

Ten eerste, mijn team. We hebben 4,5 jaar lang intensief samengewerkt en op inhoudelijk en persoonlijk vlak heb ik veel van jullie geleerd.

Gerrie, de afgelopen jaren heb je mij bijgestaan met advies. Jouw kennis en ervaring zorgden voor nieuwe invalshoeken, enthousiasme en mooie gesprekken. Onze overleggen liepen dan ook meerdere malen uit. We hebben successen gedeeld en je wist mij vaak te overtuigen van mijn eigen kunnen. Ik heb bewondering voor jou, veel dank voor deze mooie jaren.

Erik, ik kon je altijd aanspreken of je kantoor binnenlopen om even te sparren. Jij gaf mij vertrouwen in wat ik deed en gaf op een prettige wijze feedback op mijn werk, 'zal ik maar zeggen'. Ook jouw opbeurende woorden via een appje of mailtje na een presentatie kon ik waarderen. Veel dank.

Sandra, ik sta er nog steeds van te kijken hoe goed jij jouw vele taken en verantwoordelijkheden combineert. Voor zowel het begeleiden en ondersteunen van mijn proces in het algemeen, als kleine dingen zoals het welkom dat je mij gaf tijdens de EANS, dankjewel.

Petra en Silke, hoewel jullie officieel geen lid van mijn promotieteam waren, heb ik het wel zo ervaren. Petra, jij was eerst mijn docent bij de opleiding Verpleegkunde, dus het was leuk om daarna collega's te worden. Jouw prettige manier van samenwerken en de tijd die je vrij maakte om naar mijn werk te kijken waardeerde ik. Mooi om te zien hoe jij jouw eigen onderzoekslijn verder aan het vormgeven bent. Bedankt.

Silke, ook van jou heb ik veel mogen leren. Jij keek met een kritische blik naar mijn werk en het was fijn om samen te overleggen. Ik was erg onder de indruk van jouw expertise en doorzettingsvermogen. Veel dank voor de afgelopen jaren.

De beoordelingscommissie, bestaande uit prof. dr. Diana Dolmans als voorzitter en dr. Ramona Backhaus, prof. dr. Evelyn Finnema, prof. dr. Jean Muris en dr. Minke Nieuwboer. Hartelijk dank voor het lezen en beoordelen van dit proefschrift. Daarnaast wil ik prof. dr. Rob de Bie en dr. Jolanda Friesen bedanken voor het deelnemen aan de oppositie tijdens mijn verdediging.

Zonder de deelnemers uit de praktijk had ik dit proefschrift niet kunnen schrijven. Daarom wil ik de organisaties van de Academische Werkplaats Ouderenzorg Limburg bedanken, in het bijzonder MeanderGroep Zuid-Limburg en Zuyderland Thuiszorg. Alle verzorgenden, (wijk)verpleegkundigen, cliënten en andere zorgprofessionals, bedankt voor jullie betrokkenheid. Een speciaal woord van dank richt ik aan de wijkverpleegkundigen Sanne, Dymphie, Sanne, Paul, Bibi, Boukje, Tamara en Kim, bedankt voor jullie enthousiasme, deelname en input - jullie zijn een inspiratie voor het mooie beroep van de wijkverpleegkundige. 
Gedurende de eerste twee jaren van het schrijven van dit proefschrift, werkte ik als docent-onderzoeker bij Zuyd Hogeschool. Alle (oud-)collega's van Zuyd Hogeschool, bedankt! Jhoy, bedankt voor het vormgeven van onze training. Jouw kritische blik, input en expertise waren zeer waardevol. Prisca, jij startte tegelijk met mij. Ik heb je als een zeer prettige collega ervaren. Ik was ook blij met jouw hulp bij het organiseren van symposium Nurses in the Lead. Dankjewel! Stephanie, bij jullie op de kamer was ik vaak te vinden, bedankt voor alle ondersteuning (en het lekkers dat vaak klaarstond op de tafel). Alle leden van het lectoraat Wijkgerichte Zorg: bedankt voor de prettige overleggen en inhoudelijke tips.

Vervolgens had ik het voorrecht om nog twee jaar als PhD-kandidaat bij HSR aan mijn onderzoek verder te werken. Aan alle collega's bij HSR, ik ga jullie niet allemaal bij naam noemen want dan zou ik iemand vergeten, veel dank voor de gezellige lunches, koffie-breaks en sparsessies! Wel een speciaal woord van dank aan Teuni voor onze overleggen, appjes, telefoontjes en voor het mede-coderen van data. Ook een groot woord van dank aan Joanna, Brigitte, Suus en Willy-Anne, wat zou HSR zonder jullie moeten? Bedankt voor de ondersteuning de afgelopen jaren.

To my EANS colleagues, you really inspired and motivated me, during our two weeks of summer school in Lisbon and afterwards. Martha, Harm, Filip, and all the others, thank you! Inge en Kim, wat ben ik blij dat ik jullie tijdens de EANS heb leren kennen. Zowel op persoonlijk gebied als op het vlak van verpleegkundig onderzoek hebben we veel raakvlakken. Dat blijkt wel uit de groepsapp waarop regelmatig artikelen of presentaties worden rondgestuurd, alsook de tijd in Lissabon, de biertjes in de tuin bij Inge en de high-tea in Utrecht: het heeft mij allemaal goed gedaan. Hopelijk blijven wij elkaar nog lang opzoeken! Ik verheug me op jullie verdediging.

Natuurlijk wil ik ook mijn collega's bij het Laurentius Ziekenhuis bedanken, die inmiddels het nodige van mijn PhD hebben meegekregen. Denise, Linda, Francien, Romy, Judith, Rob, Marjolijn, Ria, Anne, Daphne, Har en Maartje, vanaf het begin heb ik me erg welkom gevoeld bij jullie en ik hoop dat ik nog lang onderdeel mag uitmaken van ons team en veel van jullie mag leren.

Een PhD is zo veel leuker met kamergenootjes en ik heb er gelukkig veel gehad de afgelopen jaren.

Eerst de 'flex-kamer' bij Zuyd Hogeschool, waar ik twee fijne jaren heb beleefd. Jerome, Kyra, Li-Juan, Linda, Steffy, Stephie, Jolanda, Darcy, Renee en Hester, bedankt voor alle tips en de goede gesprekken! Daarna de kamers 0.036 en 0.044 bij HSR: Martine, Vincent, Floor, Laurens, Sanne en Elina, dank voor de leuke tijd en gezelligheid. Mooi om te zien hoe jullie allemaal jullie eigen weg gaan!

Dan kamer 0.015, waar ons bord met foto's en quotes steeds gevulder werd gedurende de tijd (met uitspraken die jullie hopelijk geen publiekelijke aandacht geven). Mooi dat 
we onze traditie van bloemen voor verjaardagen zijn blijven voortzetten en nog steeds spelletjesavonden organiseren. Bedankt voor alle interesse in mijn onderzoek en alles daaromheen. Inge, ik waardeer jouw drive en doorzettingsvermogen, top dat je zo op je plek zit in Weert met Kris. Ingrid, wat was het mooi om de afronding van jouw proefschrift mee te maken. Jij was altijd geïnteresseerd, bedankt voor je betrokkenheid. Robin, jij kwam op 'onze' kamer en het was meteen gezellig, ik sta straks vooraan bij jouw promotie! Ook bedankt voor de final check van mijn proefschrift. Linda, jij was eigenlijk twee keer mijn kamergenootje, ik kon altijd bij je terecht om te sparren of met vragen, dankjewel daarvoor.

Als laatste, kamer 0.055. Wat een topkamergenootjes waren jullie. Angela, ik vind je echt een gezellig mens (met een goede garderobe) en ben blij dat ik jou heb leren kennen. Jouw ervaring met een 'dubbel-baan' kwam ook goed van pas ;-)! Roy, jouw humor kon ik waarderen, net zoals alle verhalen over jouw thuis, de kinderen en andere dingen. Fijn dat ook jij nu klaar bent, heel knap van je! Katya, bij jou kon ik terecht voor uiteenlopend advies. Mooi dat jij en Simon zo genieten samen met Hannah. Dankjewel roomies, hopelijk blijven we elkaar nog vaak spreken!

Vervolgens, mijn vrienden en familie, die onmisbaar zijn geweest gedurende dit traject. Darcy, inmiddels kunnen we spreken van een mooie vriendschap. We hebben veel van onze PhD-ervaringen met elkaar gedeeld tijdens wandelingen (avontuurlijk als we de Mike-route volgden), avonden bij 'de Zwaan' en de spelletjesavonden met Mike en Steven. Aan jouw nuchtere en wijze advies heb ik veel gehad. Ik ben heel blij met jou, bedankt voor alles, paranimf! Mike, ook jou wil ik bedanken voor jouw luisterend oor (en voor de kilo's tomaten, rabarber en andere groenten die zorgden voor de nodige vitamines). Ik vind het heel tof dat je nu zelf een PhD bent gaan doen.

Terry, samen kunnen wij niks missen en zijn we overal. Nu jij weer in Utrecht woont moeten we iets meer ons best doen om elkaar te zien, maar dit verandert niets aan onze vriendschap. Ik vind het fijn dat je op je plek zit. Met jou is alles leuker, Ter. Ook vandaag bewijst dit maar weer! Dankjewel dat je mijn paranimf wilt zijn.

Eva, jij bent altijd betrokken en positief 'op zijn Eefs' en daar heb ik veel aan gehad. Ik hoop dat we ons weekendje Bologna snel over kunnen doen. Wat een mooi mens en geweldige vriendin ben jij toch, dankjewel!

Rik en Linda, wat fijn hoe nuchter (Rik: figuurlijk) jullie in het leven staan en hoe jullie van het leven genieten. Floris, mooi om te zien hoe jouw eigen promotie traject verloopt. Ik ben vereerd dat ik jullie mijn halve huisgenoten mag noemen. Bedankt voor alles, het is altijd gezellig als we samen zijn. Op naar de vele 30 Seconds-avonden en verjaardagen (nu met Jolien!).

Lisa en Mike, Malou en Guy, Meyke en Glenn, Denise en Vic, Janou en Marvin, Claudia en Toine, Anna en Bas, Willem, Frank, Kasper en Joeri - ik heb het getroffen met zo'n 
groep. Bedankt voor alle afleiding die jullie boden tijdens de feestjes, borrels en andere momenten.

Mara, sinds jij van Amsterdam naar Maastricht bent verhuisd, hebben we elkaar vaker gezien dan de afgelopen tien jaar bij elkaar. Uren kunnen we kletsen, en wanneer ik weer eens beren op de weg zag, kon jij dit altijd prima relativeren. Jouw passie voor onderzoek is inspirerend en ik weet zeker dat jij zelf nog eens een heel mooi proefschrift gaat schrijven. Dank je voor alle fijne momenten!

Roger, de beste discussies heb ik met jou. Jij ziet dingen in een heel mooi licht, dankjewel dat ik daar deel van mag uitmaken. Daphne en Esmee, samen met Suzan plannen we regelmatig iets leuks (of proberen we toch). Dat zorgde voor genoeg afleiding de afgelopen jaren. Dankjewel voor alle gezelligheid!

Sabine, jij geeft mij het vertrouwen dat ik goed genoeg ben zoals ik ben. Suzan, met alles kan ik bij je terecht. De afgelopen jaren was mijn PhD vaak het onderwerp van gesprek. Bedankt voor jullie belangstelling, geduld en support! Jullie zijn mijn oudste vriendinnen, ik ben trots op onze hechte vriendschap.

Elyan, Eline, Anja en Roos, het afgelopen jaar hebben we een decennium aan vriendschap gevierd. Jullie boden een luisterend oor en afleiding. Langzaam beginnen we nu aan een andere fase: Sue is geboren, straks zijn we samen bruidsmeisjes op de bruiloft van Anja, en Guusje is tot de 'dog-family' toegetreden. Dankjewel dat jullie steeds met interesse naar mijn verhalen hebben geluisterd, jullie zijn de beste vriendinnen!

Robbert, wat een geluk dat ik jou heb ontmoet tijdens onze master. Ondanks dat je weer in Utrecht woont, bellen we nog steeds iedere week (of dag). Nu je zelf een opleiding tot RA volgt, is het contact alleen maar toegenomen ('nog even één strategische vraag'). Dankjewel voor het luisteren, het adviseren en soms voor het gewoon aanwezig zijn, gedurende dit traject. Jij bent heel bijzonder voor mij.

Carrie en Robby, Charles en Renata, Max en Diana, Myrthe en Marco (en Nathan en Dalia), Nettie, Magda en Seph, wij wonen redelijk verspreid in Bientina, Geleen, Zürich, Den Haag en Mestreech, maar afstand is geen punt. Een mooiere of gezelligere schoonfamilie kan ik me niet wensen. Jullie staan altijd voor ons klaar, dank voor al jullie lieve support!

Pap en mam, jullie zijn ontzettend trots en ook blij dat het nu afgerond is (en ik ook). Altijd staat de deur open, dankjewel daarvoor. Jullie boden mij kansen, vertrouwen en onvoorwaardelijke liefde. Dat is het mooiste wat er is. Ik hoop dat ik die opvoeding ooit mag doorgeven. Ken, gelukkig hebben wij een heel hechte band, altijd kan ik bij je 
terecht. Jij bent oprecht geïnteresseerd en geeft de beste adviezen, zelfs wanneer ik daar niet om vraag. Door jullie ben ik de persoon kunnen worden die ik wil zijn en heb ik dit traject de afgelopen periode kunnen volgen, dankjewel!

Paula, ook jou wil ik bedanken - voor de gezelligheid, onze weekendjes weg, maar ook voor het ontwerpen van mijn kaft. Ik geloof dat niemand dit beter had kunnen doen dan jij.

Dan nog mijn lieve oma, door de dementie begreep jij niet meer alles, maar je was altijd aan het glunderen als ik vertelde. Ik koester de herinneringen en hoop dat je aan het genieten bent met opa!

Als laatste Steven, die ik voor bijna alles mag bedanken. Mijn liefde en beste vriend, al vijf jaar zijn wij een team. Bij jou kom ik thuis, samen met lieve Nora. Ik ben trots op jou en op ons. Hopelijk mag ik jou in de toekomst net zo blijven steunen als jij bij mij doet en hebt gedaan, bij alles. 



Ruth Vogel was born in Sittard, the Netherlands, on March 17, 1993.

She completed secondary school at Lyceum Schöndeln in Roermond and obtained her Bachelor's degree in Nursing in 2015, at Zuyd University of Applied Sciences in Heerlen.

In 2016, Ruth received her Master's degree in Healthcare Policy, Innovation and Management at Maastricht University. During her studies, Ruth worked as a registered

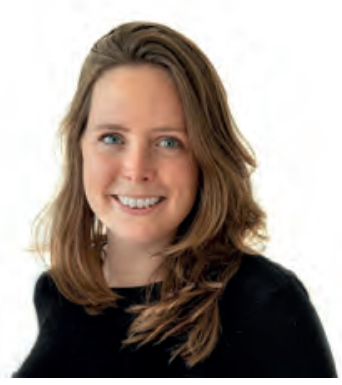
nurse within the community care setting and as a research assistant at the Health Services Research department at Maastricht University.

In 2017, Ruth started working as a researcher at Zuyd University, within the Research Centre for Community Care and the Academy of Nursing. Ruth was involved in the project 'Nurses in the Lead towards High Quality Community Care', studying the empowerment of community nurse leadership. She combined this with her work as a nurse in the community care setting. In 2019, Ruth continued with this project as a PhD candidate within the Living Lab in Ageing and Long-Term Care, at Maastricht University, resulting in this dissertation.

Alongside her research activities, Ruth was involved within educational activities, such as tutoring and lecturing students and she presented her work on national and international conferences. Furthermore, Ruth became a member of the European Academy of Nursing Science, where she has attended nursing conferences and presentations.

In October 2020, Ruth started working as a quality advisor at the Laurentius hospital, in Roermond. 



\section{List of publications}

\section{Scientific publications}

- Vogel, R., Bours, G., Metzelthin, S., Erkens, P., van Breukelen, G., Zwakhalen, S., \& van Rossum, E. (2020). The perceived behavior and barriers of community care professionals in encouraging functional activities of older adults: the development and validation of the MAINtAIN-C questionnaire. BMC health services research, 20(1), 1-12.

- Vogel, R., Bours, G., Erkens, P., Metzelthin, S., Zwakhalen, S., \& van Rossum, E. (2021). The content of the nurses in the lead programme for empowering community nurse leadership in implementing evidence. Leadership in Health Services.

- Vogel, R., Bours, G., Rooijackers, T., Metzelthin, S., Erkens, P., van Rossum, E., \& Zwakhalen, S. (2021). Process evaluation of a programme to empower community nurse leadership. BMC nursing, 20(1), 1-10.

- $\quad$ Rooijackers, T., Zijlstra, G., van Rossum, E., Vogel, R., Veenstra, M., Kempen, G., \& Metzelthin, S. (2021). Process evaluation of a reablement training program for homecare staff to encourage independence in community-dwelling older adults. BMC geriatrics, 21(1), 1-15.

- $\quad$ van der Vorst, A., Zijlstra, G., De Witte, N., Vogel, R., Schols, J., \& Kempen, G. (2017). Explaining discrepancies in self-reported quality of life in frail older people: a mixed-methods study. BMC geriatrics, 17(1), 251.

\section{National publications}

- Vogel, R., Bours, G., Metzelthin, S., Hooijen, S., Erkens, P., Zwakhalen, S., van Rossum, E. [Kwaliteit van zorg vraagt om wijkverpleegkundig leiderschap]. TvZ Verpleegkunde in praktijk en wetenschap, 32-25, December 2018.

- Vogel, R. Veranderende zorg vergt professioneel leiderschap van wijkverpleegkundigen. Meander Magazine, December 2017.

- $\quad$ Riëtte D., Hooijen, S., Daniels, P., Vogel, R., Bours G. Wijkverpleegkundigen nemen de leiding. ZonMw Mediator nieuwsbrief 35, May 2019.

- $\quad$ van der Vorst, A., Zijlstra, G., De Witte, N., Vogel, R., Schols, J., Kempen, G., \& DSCOPE Consortium (2018). [Het verklaren van verschillen in ervaren kwaliteit van leven van kwetsbare ouderen: een 'mixed-method' onderzoek]. Tijdschrift voor Gerontologie en Geriatrie, 1-13. 


\section{Presentations}

\section{Scientific presentations}

- Vogel, R., Bours, G, Metzelthin, S., Erkens, P., Zwakhalen, S., van Rossum, E. Nurses in the Lead towards High Quality Community Care: Adaptation of the TIP-Toolbox. Elevator Pitch presented at 8e Wetenschappelijk Symposium, Zuyderland MC, Geleen, the Netherlands, June 2017.

- Vogel, R., Bours, G., Metzelthin, S., Erkens, P., Zwakhalen, S., van Rossum, E. Supporting nurse leadership in Dutch community care. 1st International Conference of the German Society of Nursing Science, Berlin, Germany, May 2018.

- Vogel, R., Bours, G., Metzelthin, S., Erkens, P., Zwakhalen, S., van Rossum, E. Empowerment of nurse leadership in community care teams: a user centred design. 17th European Doctoral Conference in Nursing Science, Maastricht, the Netherlands, June 2018.

- Vogel, R., Bours, G., Metzelthin, S., Erkens, P., Zwakhalen, S., van Rossum, E. Empowerment of nurse leadership in community care teams: a user centred design. 3rd CARE4 - International Scientific Nursing and Midwifery Congress, Leuven, Belgium, February 2019.

- Vogel, R., Bours, G., Metzelthin, S, Erkens, P., Zwakhalen, S., van Rossum, E. Stimuleren van de zelfredzaamheid van thuiswonende ouderen: ervaren gedrag en barrières van verpleegkundigen en verzorgenden. Nationaal Gerontologiecongres, Ede, the Netherlands, November 2019.

\section{Poster presentations}

- Vogel, R., Bours, G., Metzelthin, S, Erkens, P., Zwakhalen, S., van Rossum, E. Nurses in the Lead towards High Quality Community Care: Adaptation of the TIP-Toolbox. Poster session presented at: The Netherlands Organisation for Health Research and Development network conference: Future Proof Nursing - Challenges and Opportunities; 2017; June 9; Utrecht, The Netherlands.

- Vogel, R., Bours, G., Metzelthin, S, Erkens, P., Zwakhalen, S., van Rossum, E. Nurses in the Lead towards High Quality Community Care: Adaptation of the TIP-Toolbox. Poster session presented at: 8th Scientific Symposium, Zuyderland MC; 2017 June 29; Geleen, The Netherlands.

- Vogel, R., Bours, G., Metzelthin, S, Erkens, P., Zwakhalen, S., van Rossum, E. Nurses in the Lead, an Intervention to Empower Leadership of Community Nurses. A Process Evaluation. Scientific Symposium, Zuyderland MC; 2019 June 27; Geleen, The Netherlands. 


\section{Living Lab in Ageing and Long-term care}




\section{LIVING LAB IN AGEING AND LONG-TERM CARE}

This thesis is part of the Living Lab in Ageing and Long-Term Care, a formal and structural multidisciplinary network consisting of Maastricht University, nine long-term care organizations (MeanderGroep Zuid-Limburg, Sevagram, Envida, Cicero Zorggroep, Zuyderland, Vivantes, De Zorggroep, Land van Horne \& Proteion), Intermediate Vocational Training Institutes Gilde and VISTA college and Zuyd University of Applied Sciences, all located in the southern part of the Netherlands. In the Living Lab we aim to improve quality of care and life for older people and quality of work for staff employed in long-term care via a structural multidisciplinary collaboration between research, policy, education and practice. Practitioners (such as nurses, physicians, psychologists, physio- and occupational therapists), work together with managers, researchers, students, teachers and older people themselves to develop and test innovations in long-term care.

\section{ACADEMISCHE WERKPLAATS OUDERENZORG ZUID-LIMBURG}

Dit proefschrift is onderdeel van de Academische Werkplaats Ouderenzorg Limburg, een structureel, multidisciplinair samenwerkingsverband tussen de Universiteit Maastricht, negen zorgorganisaties (MeanderGroep Zuid-Limburg, Sevagram, Envida, Cicero Zorggroep, Zuyderland, Vivantes, De Zorggroep, Land van Horne \& Proteion), Gilde Zorgcollege, VISTA college en Zuyd Hogeschool. In de werkplaats draait het om het verbeteren van de kwaliteit van leven en zorg voor ouderen en de kwaliteit van werk voor iedereen die in de ouderenzorg werkt. Zorgverleners (zoals verpleegkundigen, verzorgenden, artsen, psychologen, fysio- en ergotherapeuten), beleidsmakers, onderzoekers, studenten en ouderen zelf wisselen kennis en ervaring uit. Daarnaast evalueren we vernieuwingen in de dagelijkse zorg. Praktijk, beleid, onderzoek en onderwijs gaan hierbij hand in hand. 


\section{PROEFSCHRIFTEN ACADEMISCHE WERKPLAATS OUDERENZORG ZUID- LIMBURG}

Ruth Vogel. Nurses in the Lead: empowering community nurse leaders to implement evidence into practice. 2021

Roy Haex. Take a look through my eyes: The development of an experienced quality measure with clients, informal, and formal caregivers in Dutch home care. 2021

Fabian Groven. The bed bath with or without water? It's a wash! Experiences with the washing without water intervention used for the bed bath. 2021

Sascha Bolt. The fundamentals of a DEDICATED palliative approach to care for people with dementia. 2021

Angela Mengelers. To risk or to restrain? Involuntary treatment use in people with dementia living at home. 2021

Katya Sion. Connecting Conversations. Experienced quality of care from the resident's perspective: a narrative method for nursing homes. 2021

Linda Hoek. Change begins with choice. Supporting the autonomy of nursing home residents with dementia through partnership. 2020

Mirre den Ouden. Every step counts. Daily activities of nursing home residents and the role of nursing staff. 2018

Theresa Thoma-Lürken. Innovating long-term care for older people. Development and evaluation of a decision support app for formal caregivers in community-based dementia care. 2018

Eveline van Velthuijsen. Delirium in older hospitalised patients: diagnosis and management in daily practice. 2018

Bram de Boer. Living at a green care farm. An innovative alternative for regular care in nursing homes for people with dementia. 2017

Nienke Kuk. Moving forward in nursing home practice. Supporting nursing staff in implementing innovations. 2017

Irma Everink. Geriatric rehabilitation. Development, implementation and evaluation of an integrated care pathway for older patients with complex health problems. 2017

Ramona Backhaus. Thinking beyond numbers. Nursing staff and quality of care in nursing homes. 2017

Martin Van Leen. Prevention of pressure ulcers in nursing homes, a big challenge. 2017

Mariëlle Daamen-Van der Velden. Heart failure in nursing home residents. Prevalence, diagnosis and treatment. 2016

Armand Rondas. Prevalence and assessment of (infected) chronic wounds. 2016

Hanneke Beerens. Adding life to years. Quality of life of people with dementia receiving long-term care. 2016 (Cum Laude)

Donja Mijnarends. Sarcopenia: a rising geriatric giant. Health and economic outcomes of community-dwelling older adults with sarcopenia. 2016

Tanja Dorresteijn. A home-based program to manage concerns about falls. Feasibility, effects and costs of a cognitive behavioral approach in community-dwelling, frail older people. 2016 
Basema Afram. From home towards the nursing home in dementia. Informal caregivers' perspectives on why admission happens and what they need. 2015

Noemi Van Nie-Visser. Malnutrition in nursing home residents in the Netherlands, Germany and Austria. Exploring and comparing influencing factors. 2014

Esther Meesterberends. Pressure ulcer care in the Netherlands versus Germany 0-1. What makes the difference? 2013

Math Gulpers. EXBELT: expelling belt restraints from psychogeriatric nursing homes. 2013

Hilde Verbeek. Redesigning dementia care. An evaluation of small-scale homelike care environments. 2011

Judith Meijers. Awareness of malnutrition in health care, the Dutch perspective. 2009

Ans Bouman. A home visiting program for older people with poor health. 2009

Monique Du Moulin. Urinary incontinence in primary care, diagnosis and interventions. 2008

Anna Huizing. Towards restraint free care for psychogeriatric nursing home residents. 2008

Pascalle Van Bilsen. Care for the elderly, an exploration of perceived needs, demands and service use. 2008

Rixt Zijlstra. Managing concerns about falls. Fear of falling and avoidance of activity in older people. 2007

Sandra Zwakhalen. Pain assessment in nursing home residents with dementia 





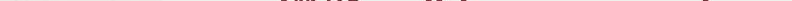

